\title{
FELIPE PEROZZO DALTOÉ
}

Transplante de germe dental: estudo da correlação entre posição do implante, presença de tecido ósseo no leito receptor e fase de desenvolvimento do germe transplantado com possível neoformação de tecido nervoso e vascular na polpa dental 


\section{FELIPE PEROZZO DALTOÉ}

Transplante de germe dental: estudo da correlação entre posição do implante, presença de tecido ósseo no leito receptor

e fase de desenvolvimento do germe transplantado com possível neoformação de tecido nervoso e vascular na polpa dental

Dissertação apresentada à Faculdade de Odontologia da Universidade de São Paulo para obter o título de Mestre pelo Programa de Pós-Graduação em Odontologia.

Área de Concentração: Patologia Bucal

Orientadora: Profa. Dra. Andrea Mantesso

São Paulo 


\section{FOLHA DE APROVAÇÃO}

Daltoé FP. Transplante de germe dental: estudo da correlação entre posição do implante, presença de tecido ósseo no leito receptor e fase de desenvolvimento do germe transplantado com possível neoformação de tecido nervoso e vascular na polpa dental [Dissertação de Mestrado]. São Paulo: Faculdade de Odontologia da USP; 2010.

São Paulo,

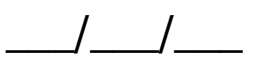

\section{Banca Examinadora}

1) $\operatorname{Prof}(a) \cdot \operatorname{Dr}(a)$ :

Titulação:

Julgamento:

Assinatura:

2) $\operatorname{Prof}(a) \cdot \operatorname{Dr}(a) .:$

Titulação:

Julgamento:

Assinatura:

3) $\operatorname{Prof}(a) \cdot \operatorname{Dr}(a)$. :

Titulação:

Julgamento: Assinatura: 
Dedico estes anos de estudo aos meus pais, que fizeram o possível e o impossível pra ver a mim e ao meu irmão felizes, que sempre me serviram de exemplo de perseverança e dedicação e que me proveram todos os valores necessários pra tornar-me um homem digno, de caráter idôneo e de coração e mente abertos.

Dedico também ao meu irmão e cunhada por me darem o verdadeiro sentido a palavra "família" e, portanto, representarem o que de mais valioso a vida pode nos oferecer: amor.

E, por fim, a todos os animais utilizados nesta pesquisa e que para tal tiveram as suas vidas usurpadas em prol da ciência. 


\section{AGRADECIMENTOS}

A Deus, por me dar nesta vida saúde plena e tantas oportunidades de evoluir.

Aos meus pais, por representarem o que há de melhor na essência do ser e por, incansavelmente, tentarem repassá-la com amor aos seus filhos. "Somos anjos de uma aza só. Voamos apenas quando estamos juntos".

Ao meu irmão e cunhada por me servirem de exemplo de dedicação, dignidade e respeito a vida.

Aos demais familiares por tantos momentos de alegria vividos juntos. A vida faria muito menos sentido sem vocês.

Aos verdadeiros amigos, que, juntos de mim, onde quer que estivessem, compartilharam dos meus sonhos, se inquietaram com os meus problemas e vibraram com as minhas conquistas. Vocês são um pouco de mim e, orgulhosamente, eu sou muito de vocês.

A minha orientadora, pelo brilhante papel de guia nos meus estudos e pelo grande exemplo de dedicação, persistência e excelência na carreira de docente e pesquisadora.

Aos demais professores do Departamento de Patologia Bucal da FOUSP, pelo acolhimento na sua casa e por todos os ensinamentos, gentilmente, transmitidos.

Ao Professor Victor Elias Arana-Chavez, extensivo aos seus alunos, pela amizade e apoio na realização deste trabalho. 
Aos queridos amigos e grandes mestres da minha querida casa UFSC: Carlos Renato, Elena, Filipe, Inês Beatriz, Liliane, Maninha, Nelson e Sônia. Vocês me serviram de inspiração pra seguir a carreira que escolhi, me incentivaram o suficiente pra eu chegar aonde estou e, certamente, me servirão de exemplos de motivação pra alcançar tudo aquilo de bom que a vida ainda pode me proporcionar. Aos meus colegas do Curso de Pós-Graduação pelo agradável convívio e por tantos momentos de partilha, sejam dos sonhos, das angústias ou das realizações.

A todos os funcionários da USP que direta ou indiretamente tornaram esse trabalho um sonho factível.

E, por fim, a todos aqueles que em algum dia da minha vida me subestimaram ou, de alguma maneira, me serviram de exemplo negativo. Foi graças ao seus olhares "zelosos" que muitas vezes busquei dentro de mim os erros que, de fora, vocês apontavam. Ironicamente, na maioria das vezes, o que encontrava não eram defeitos, mas sim coisas que poderiam ser aprimoradas. Desta forma, a cada busca, encontrei ainda mais motivação e persistência pra me tornar uma pessoa cada vez mais aquilatada e distinta de vocês: alguém que não só aposta ao máximo no próximo, mas que aposta e dá o máximo de si. 
"E assim, depais de muita esperar, num dia cama autra qualquer, decidi triunfar.

Decidi nãa esperar as oportunidades e, sim, eu mesma buscá-las.

Decidi ver cada problema cama uma opartunidade de encontrar uma soluçãa.

Decidi ver cada deserta cama uma passibilidade de encontrar un oásis.

Decidi ver cada noite cama un mistéria a resolver.

Decidi ver cada dia coma uma nova opartunidade de ser feliz.

Naquele dia, descobri que meu única rival nãa era mais que minhas próprias limitaçäes e que enfrentá-las era a única e melhor farma de superá-las.

Naquele dia. descabi que eu nãa era a melhor e que taluez eu nunca tivesse sida.

Deixei de me impartar cam quem ganha ou perde.

Agara me imparta simplesmente saber a que melhor fazer.

Aprendi que a difécil nãa é chegar lá em cima e. sim. deixar de subir.

Aprendi que a melhor triunfa é pader chamar alguém de "amiga".

Descabri que a amor é mais que un simples estado de enamaramenta.

$O$ amar é uma filosofia de vida.

Naquele dia, deixei de ser un reflexa dos meus escassos triunfos passados e passei a ser uma tênue luz no presente.

Aprendi que de nada serve ser luz se nãa iluminar a caminha das demais.

Naquele dia, decidi trocar tantas coisas...

Naquele dia, aprendi que as sonhos existem para tormar-se realidade.

E. desde aquele dia. já nãa durma para descansar.

Simplesmente durmo para sonhar."

\section{Walt Disney}


Daltoé FP. Transplante de germe dental: estudo da correlação entre posição do implante, presença de tecido ósseo no leito receptor e fase de desenvolvimento do germe transplantado com possível neoformação de tecido nervoso e vascular na polpa dental [Dissertação de Mestrado]. São Paulo: Faculdade de Odontologia da USP; 2010.

\section{RESUMO}

A odontologia moderna, mesmo usando as suas técnicas mais primorosas, na prática, ainda recupera a perda dental com implantes metálicos recobertos por coroas protéticas. Há um empenho coletivo dos cientistas em criar técnicas de desenvolvimento dental in vitro na busca por maneiras de recuperar, de maneira biológica, a ausência dental. Já é possível criar estruturas similares a dentes a partir de células-tronco de origem dental (polpa de dentes permanentes e decíduos) e não dental (células-tronco embrionárias, células-tronco da medula óssea e da crista neural) por meio de recombinação dos tecidos epiteliais e mesenquimais de germes dentais. As técnicas de reconstrução tecidual nunca estiveram tão perto do desenvolvimento da "terceira dentição" mas a ciência ainda tem muito a aprender no que concerne o estudo da biologia dental e engenharia de tecidos. Não basta saber como um dente se desenvolve; há de se entender como ele interage com o organismo do qual faz ou fará parte. É com esta preocupação que nos propomos a estudar se pode haver uma correlação entre o desenvolvimento do sistema nervoso e vascular de um germe dental transplantado com a posição que ele é implantado e/ou com a presença de tecido ósseo que no leito receptor. Ademais, buscamos saber se o estágio de desenvolvimento do germe dental a ser transplantado pode influenciar a formação de tecido nervoso e vascular na polpa dental ou não. Nossos 
resultados revelaram que o local do sítio do implante influencia diretamente o desenvolvimento dental e que isto é tempo dependente. A vascularização e a reinervação da polpa dental nos espécimes implantados nas tíbias é mais semelhante ao grupo controle que os implantados nos rins e isto independe da posição de implantação dental. Entretanto, a polpa dental dos germes implantados nos rins parece estar comumente mais sadia, conter mais odontoblastos viáveis e ser capaz de produzir tecidos mineralizados como a osteodentina.

Palavras-chave: desenvolvimento dental, engenharia tecidual, vasculogênese, angiogênese e neurogênese. 
Daltoé FP. Correlation between position of implantation, presence of bone and tooth development stage in the moment of the transplant with nervous and vascular development in transplanted teeth [Dissertação de Mestrado]. São Paulo: Faculdade de Odontologia da USP; 2010.

\section{ABSTRACT}

Contemporary dentistry, even using modern techniques, still deal with missing teeth using metal implants coated by prosthetic crowns. However, there is a worldwide effort to develop a biotooth using in vitro techniques. In this way it is already possible to generate structures similar to teeth using recombination of odontogenic and non odontogenic cells in tissue engineering experiments. The transplant of the recombined cells into a host is a necessary and major step to obtain the biotooth. In this context, at the same time that the development of an appropriate sensorial and vascular system in the biotooh is required, there are many unclear questions about it. Therefore, herein we intend to analyze (I) whether may exist a correlation between the stage of development and vascular and nervous re-growth in the dental pulp after tooth transplantation; (II) if the absence or presence of bone could influence this processes or (III) if the position of implantation could change the vascular and/or nervous development in the transplanted tooth. Our results showed that the site of implantation directly alter tooth development modifying morphogenesis and expression of different vascular, perivascular and neural markers in a time dependant way. The re-growth of the vascular and neural tissue on samples transplanted to the tibia is more similar to the control group than the kidney ones and it is non dependant of the position of implantation. However, the 
pulp tissue of the samples transplanted under the kidney capsule seemed to be healthier as they were capable of producing mineralized tissue such as osteodentin and still had live odontoblasts.

Keywords: tooth development, tissue engineering, vasculogenesis, angiogenesis and neurogenesis 


\section{LISTA DE ABREVIATURAS E SIGLAS}

min Minutos

h Horas

DAB Do inglês 3,3'- diaminobenzidine, traduzido como 3,3'diaminobenzidina

PBS Do inglês Phosphate Buffered Saline, traduzido como Tampão Fosfato Salino

pH Potencial Hidrogeniônico

VEGF Do inglês Vascular Endothelial Growth Factor, traduzido como fator de crescimento derivado de plaqueta

PDGFR- $\boldsymbol{\beta}$ Do inglês Beta-type platelet-derived growth factor receptor, traduzido como receptor do fator de crescimento derivado de plaqueta tipo beta

UI Unidades internacionais de medida

mg Miligramas

$\mathbf{m m} \quad$ Micrometros

mI Mililitros

Kg Kilogramas

BSA Do inglês bovine serum albumin, traduzido como albumina de soro bovino 


\section{LISTA DE SÍMBOLOS}

$\begin{array}{ll}\text { B } & \text { Beta } \\ { }^{\mathbf{0}} & \text { Graus centígrados } \\ \mathbb{B} & \text { Registro de marca } \\ \boldsymbol{\mu} & \text { Micrômetro } \\ \# & \text { Número de catálogo } \\ \mathbf{0} & \text { Porcentagem } \\ \mathbf{C a}^{+\mathbf{2}} & \text { Íon cálcio }\end{array}$




\section{SUMÁRIO}

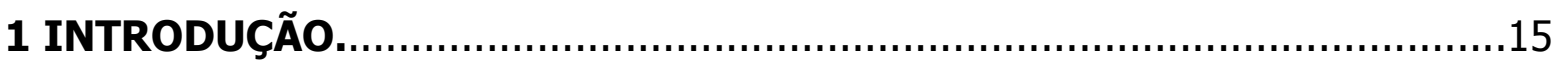

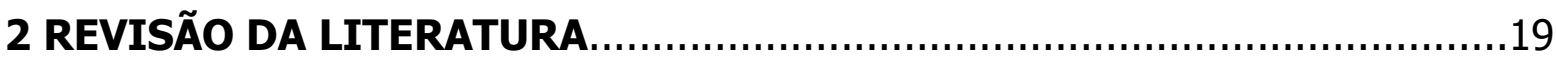

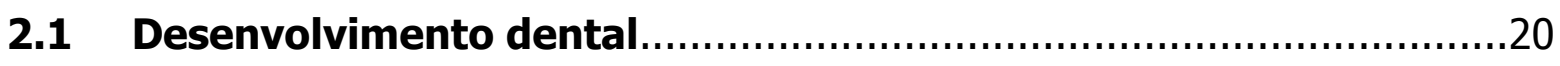

2.2 2.2 Formação do tecido nervoso na polpa dental ao longo da odontogênese.

2.3 Formação do sistema vascular da polpa dental durante a

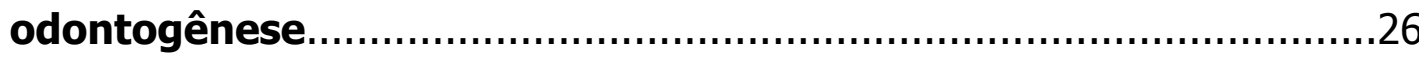

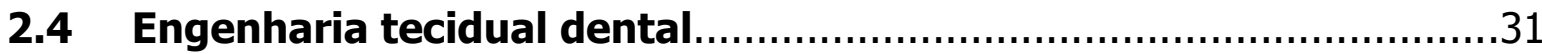

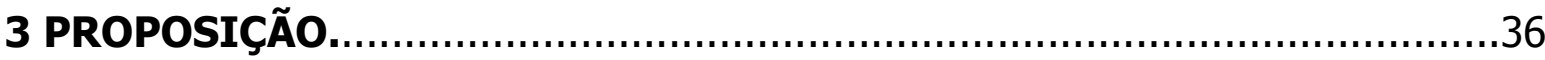

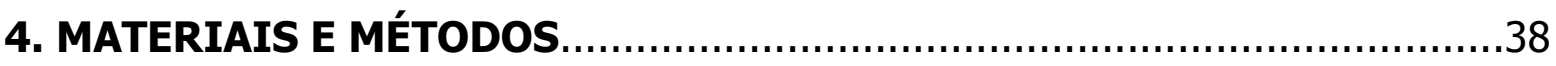

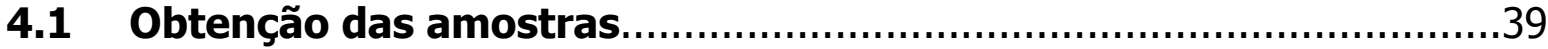

4.2 Avaliação do desenvolvimento nervoso e vascular nos germes

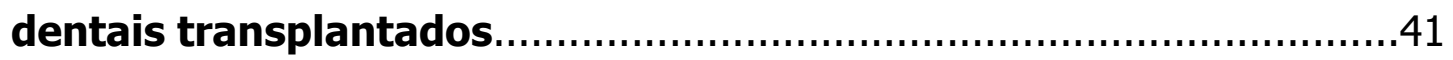

4.2.1 Fixação e processamento histotécnico...................................................43

4.2.2 Reação de imunoistoquimica..............................................................

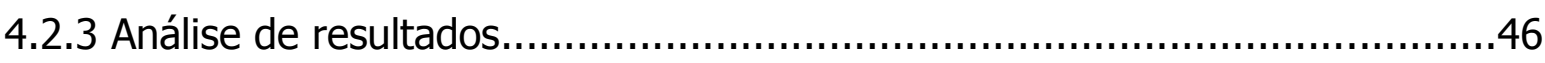

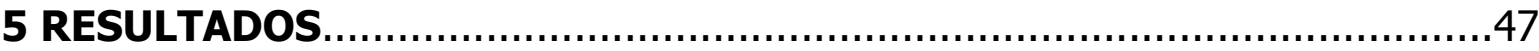

5.1 Animais que receberam os germes dentais dos doadores com 2 dias de vida pós-natal e com proservação de 3 dias.

5.2 Animais que receberam os germes dentais dos doadores com 2 dias de vida pós-natal e com proservação de 7 dias....................................51

5.3 Animais que receberam os germes dentais dos doadores com 2 dias de vida pós-natal e com proservação de 11 dias.

5.4 Animais que receberam os germes dentais dos doadores com 6 dias de vida pós-natal e com proservação de 3 dias..................................70

5.5 Animais que receberam os germes dentais dos doadores com 6 dias de vida pós-natal e com proservação de 7 dias. 
5.6 Animais que receberam os germes dentais dos doadores com 6 dias de vida pós-natal e com proservação de 11 dias..................................82

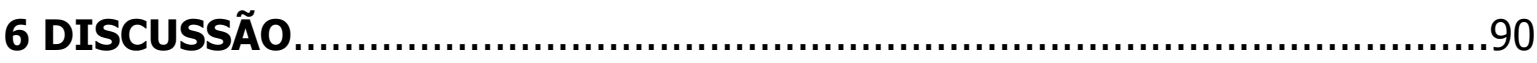

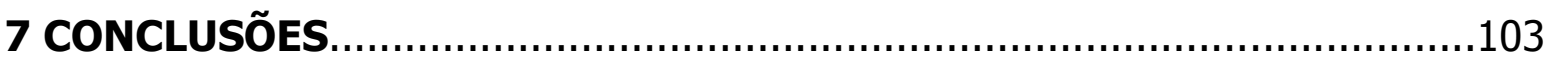

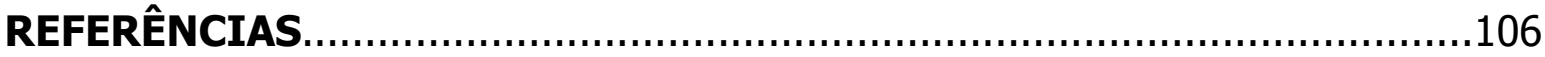

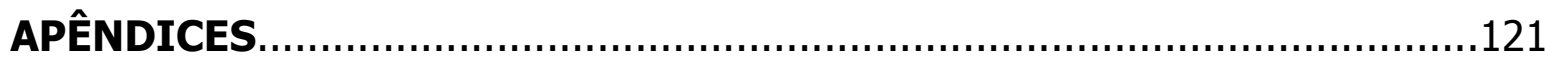

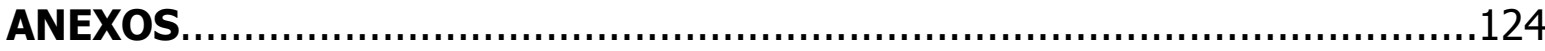




\section{INTRODUÇÃO}

Nós os usamos todos os dias e os cuidamos periodicamente, mas, mesmo assim, os dentes ainda são perdidos com muita freqüência. Cárie e doença periodontal são as duas principais razões para que isso ocorra, mas trauma e doenças genéticas também estão entre os fatores etiológicos mais prevalentes [1].

A perda dental leva a problemas que vão muito além dos causados pela ausência física de um órgão. Os dentes têm influencia direta e indireta no bem estar físico, psicológico e no convívio social dos seres humanos.

Apesar da perda dental ocorrer por gerações e gerações ao longo da evolução da humanidade, a reposição de um elemento dental ainda se dá de maneira artificial na prática odontológica. A odontologia, mesmo no apogeu da sua primordialidade, ainda usa implantes metálicos acoplados a coroas protéticas para reabilitar os seus pacientes. Esses métodos, apesar de efetivos, estão longe de repor qualita e quantitativamente todas as estruturas biológicas perdidas, a exemplo do ligamento periodontal e da propriocepção nervosa.

Nesse ínterim, a necessidade de se desenvolver novas técnicas de reposição de estruturas dentais aliada a recentes avanços das pesquisas com células-tronco e engenharia de tecidos trouxe grandes inovações que, ainda que em caráter experimental, estão quebrando paradigmas e prometem revolucionar o futuro da odontologia.

Atualmente, dois grandes grupos de pesquisa se destacam por feitos nessas áreas. O grupo da cientista Pamela Yelick foi pioneiro em demonstrar, no ano de 2002, que células de germes dentais podiam ser cultivadas in vitro, plaqueadas sobre moldes de polímeros biodegradáveis e que, quando implantadas em camundongos imunocomprometidos, podiam formar estruturas similares a dentes [2]. Dois anos mais tarde, o grupo britânico chefiado pelo Professor Paul Sharpe, tornou público resultados de experimentos onde a reassociação (também conhecida como recombinação tecidual) de células odontogênicas e não odontogênicas, foi capaz de formar dentes, ou seja, essas células mostraram-se 
capazes de se auto-reagregarem, auto-reorganizarem e, surpreendentemente, foram capazes de formar tecidos tipicamente dentais, mesmo quando não possuíam, de fato, origem odontogênica [3].

Tais considerações oferecem oportunidades excitantes para a reposição de um dente perdido ou ausente. Independente da técnica utilizada, os pesquisadores acreditam que a aplicabilidade clínica futura de tais descobertas não será, a primeiro modo, realizada em apenas uma etapa. A princípio, seria necessário o cultivo de células precursoras dos tecidos dentais in vitro, indução da diferenciação dessas células nos diferentes tecidos que compõem os dentes, seguido de implante dos mesmos em um sítio ectópico. Por último, especula-se que somente quando o biodente estiver apto para ser transplantado para o local anatômico definitivo na cavidade bucal é que tal procedimento seria realizado.

Apesar das perspectivas promissoras, do ponto de vista de aplicabilidade clínica, ainda existem preocupações a esclarecer: quais as fontes celulares mais acessíveis e mais viáveis para bioengenharia dental? Que tratamento essas células devem receber in vitro para que formem as estruturas desejadas? Qual seria o sítio ectópico adequado para o desenvolvimento transitório do biodente? Qual o momento correto para se realizar o transplante do biodente para os maxilares?

$\mathrm{Na}$ busca por algumas dessas respostas, surgem ainda mais questionamentos: até que ponto o fato de se utilizarem células mais jovens ou mais diferenciadas (adultas) para a construção de um biodente pode afetar o seu desenvolvimento? Até que ponto a eleição de um ou outro sítio ectópico para o desenvolvimento transitório do biodente pode comprometer 0 seu desenvolvimento? Será que o biodente vai possuir um aporte sanguíneo adequado na polpa dental? E inervação? Será que o sítio ectópico a ser escolhido para o desenvolvimento dental durante o período de transição até o momento do transplante para os maxilares seria um ponto crucial para isto? Elencar um lugar onde ao invés de presença de tecido ósseo, uma vasta vascularização e baixa imunidade pareçam as grandes vantagens, seria uma melhor opção? Essas e outras perguntas ainda não estão bem esclarecidas na literatura científica produzida até o 
momento e, foram justamente elas que motivaram e conduziram a realização deste trabalho.

Sendo assim, objetivamos avaliar se a presença ou ausência de tecido ósseo no sítio ectópico de transplante de um germe dental ou se o estágio de desenvolvimento do mesmo pode influenciar o padrão de formação do tecido vascular e nervoso no dente implantado ou ainda se a posição de implantação do germe dental pode influenciar tais processos. 
Revisão de Literatura 


\section{REVISÃO DA LITERATURA}

\subsection{Desenvolvimento dental}

Os dentes são estruturas específicas dos vertebrados e que, assim como os outros tecidos do corpo humano, se desenvolvem através de uma série de interações recíprocas entre célula-célula e célula-organismo. Em se tratando de desenvolvimento dental, essas interações acontecem entre o epitélio bucal, o mesênquima subjacente e os tecidos de suporte dos maxilares [4].

Nos mamíferos, apesar de cada dente se desenvolver como uma estrutura independente e de se formarem tipos dentários morfologicamente diferentes (incisivos, molares, etc), o processo de desenvolvimento do dente - chamado odontogênese - é basicamente o mesmo [5].

O primeiro sinal morfológico de desenvolvimento dos dentes é o espessamento do epitélio bucal em regiões específicas da cavidade bucal. O tecido bucal que ocupa a posição correspondente aos futuros rebordos alveolares maxilar e mandibular chama-se lâmina dental e, a medida que as células epiteliais da lâmina dental se multiplicam, o fazem em direção ao mesênquima subjacente e formam uma estrutura morfologicamente arredondada, chamada botão. Esta, por sua vez, dá o nome de fase de botão a esta etapa do desenvolvimento dental [5].

A partir de então, o contínuo crescimento do botão epitelial dental não ocorre de maneira uniforme. Há uma maior proliferação celular nas bordas dessa estrutura e, a medida que isso ocorre, células ectomesenquimais se condensam na base do botão e agem, provavelmente, como uma zona de resistência central, o que somado a uma maior proliferação das margens, leva o germe dental a desenvolver uma concavidade na sua região inferior e a assumir uma forma semelhante a um capuz (fase de capuz). Durante a fase de capuz, o mesênquima que rodeia o germe em desenvolvimento também se condensa, de maneira que essas células alinhem-se e formem uma cápsula que separa o germe dental do restante do mesênquima adjacente. Essa condensação celular periférica, 
denominada folículo dental ou saco dentário, é responsável pela futura formação do periodonto de inserção do dente, isto é, do cemento, do ligamento periodontal e do osso alveolar. A região interna do capuz passa a se chamar papila dentária e as células mesenquimais nela contidas formarão, no decorrer do desenvolvimento dental, a dentina e a polpa dental [5].

Ainda na fase de capuz, os primeiros vasos capilares penetram no folículo dental e essa estrutura passa a ter então um importante papel na nutrição do germe dental [5].

Decorrida a fase de capuz, as células epiteliais continuam a se proliferar, porém mais lentamente; a papila dentária se torna mais profunda e dá ao germe uma aparência morfológica semelhante a um sino, o que outorga a denominação de campânula a essa fase [5].

É na fase de campânula que ocorrem os primeiros eventos de cito e morfodiferenciação e que, consequentemente, células da papila dental se diferenciam em odontoblastos $\mathrm{e}$ as células epiteliais se diferenciam em ameloblastos [5].

Por fim é também na fase de campânula que a lamina dental começa a se fragmentar. No final dessa fase e no inicio da fase de coroa o germe já estará confinado dentro do osso alveolar, separado definitivamente da lâmina dental, e em condições de formar todos os demais tecidos dentais [5].

$\mathrm{Na}$ fase de coroa inicia-se a deposição das matrizes do esmalte e dentina para formar a porção mineralizada da coroa dental. Pra isso, as células do epitélio interno se diferenciam, inicialmente, em odontoblastos cuja função é produzir a matriz dentinaria. Essa deposição inicia-se na região de cúspide e progride em direção à região cervical. Em seguida, sob influencia da deposição de matriz dentinária, a células do epitélio se diferenciam em ameloblastos e passam a secretar a matriz do esmalte [5].

A medida que a coroa se desenvolve, a alça cervical dobra-se em aproximadamente 90 graus. Dá-se assim origem a uma estrutura denominada diafragma epitelial a qual marca o início da formação da raiz (fase de raiz). 0 diafragma epitelial é mantido até o final do crescimento da raiz quando então tem o papel de formar o ápice radicular [5]. 
Durante o desenvolvimento radicular, as células da bainha radicular de Hertwig se diferenciam em odontoblastos e formam a dentina radicular; ao mesmo tempo, induzem as células do folículo dental a se diferenciarem em fibroblastos e cementoblastos, os quais formarão o ligamento periodontal e cemento, respectivamente [5].

Conforme abordado anteriormente, a odontogênese é um processo comum a todos os mamíferos. Além dos humanos, tal processo é amplamente estudado e conhecido em camundongos e ratos. A dentição de cada arcada destes animais é composta por um par de incisivos e três pares de molares, sendo que estes últimos estão separados dos incisivos por um diastema [6].

Em virtude dos incisivos dos roedores terem um crescimento contínuo ao longo de toda a vida desses animais e do desenvolvimento dos molares ser muito semelhante ao dos molares dos seres humanos - ou seja, ter um crescimento limitado - optou-se por padronizar, nesta pesquisa, apenas o estudo do desenvolvimento dos primeiros molares superiores destes animais. Por esse motivo, vale conhecer as fases da odontogênese em ratos (da raça Wistar, no nosso caso) conforme apresentado na tabela abaixo (Tabela 2.1).

Tabela 2.1 - Cronologia de desenvolvimento dental em ratos Wistar [7]

\begin{tabular}{l|l|l|l|l|l|l}
\hline Cronologia & F15* & F17* & F19* & NN** & D3*** & D5*** \\
\hline Morfologia & Botão & Capuz & $\begin{array}{l}\text { Campânula } \\
\text { inicial }\end{array}$ & $\begin{array}{l}\text { Campânula } \\
\text { tardia }\end{array}$ & $\begin{array}{l}\text { Coroa } \\
\text { inicial }\end{array}$ & $\begin{array}{l}\text { Coroa } \\
\text { completa }\end{array}$ \\
\hline
\end{tabular}

*Dias de vida intra-uterina (fetal)

$* *$ Rato neonato

$* * *$ Dias de vida pós-natal 


\subsection{Formação do tecido nervoso na polpa dental ao longo da odontogênese}

Os dentes, a pesar de não serem essenciais para a vida, são significativos para a sobrevivência dos mamíferos e, portanto, a presença de um sistema sensorial que os proteja é de suma importância [8].

Nos mamíferos, os dentes adquirem uma inervação sensorial proveniente do gânglio trigêmio e a formação das ramificações terminais é um evento que se estende durante a vida pós-natal [8].

Em ratos, o gânglio trigêmio forma-se por volta do nono dia de vida embrionária (E9) [9-10]. Isso coincide com o momento em que o epitélio bucal atinge o potencial para formação dental [9, 12], mas antecede a formação da lâmina dental [9].

A medida que o epitélio da lâmina dental sofre um espessamento nos pontos de formação dos futuros dentes, os axônios provenientes do gânglio trigêmio crescem em suas direções [13]. Durante os estágios subseqüentes de desenvolvimento - fases de capuz e campânula - os axônios continuam o seu crescimento e formam um plexo nervoso abaixo do germe dental. Tanto em humanos quanto em ratos, as fibras nervosas emergem desse plexo e penetram na polpa de tal apenas após o início da mineralização da coroa dental [14].

Durante a última década, o uso de técnicas de biologia molecular para elucidação de assuntos relacionados com a odontogênese aumentou significativamente o conhecimento sobre as interações epitélio-mesenquimais relacionadas ao processo de formação do sistema nervoso dental $[15,16]$, porém, assim mesmo, pode-se considerar que o conhecimento desenvolvido a esse respeito ainda é muito limitado [17].

Acredita-se que a inervação dental seja um sistema com alta plasticidade e que 0 crescimento e o estabelecimento de inervações terminais durante 0 desenvolvimento dental sejam controlados localmente por sinais moleculares [18]. Um exemplo disso seria o período de "nova" inervação que ocorre nos dentes permanentes quando estes sucedem os decíduos [19]. 
Muitos estudos têm revelado uma variedade de imunomarcadores que podem ser úteis para a identificação das células nervosas e são extensivamente utilizados para o estudo das mesmas. A exemplo destes, podemos citar as proteínas S100 e nestin, sobre as quais abordar-se-á mais profundamente a seguir:

$\underline{\mathrm{S} 100}$

As proteínas S100 (100 \% solúveis em sulfato de amônio) pertencem a uma grande família de proteínas citoplasmáticas e $\mathrm{Ca}^{+2}$ ligantes no meio extracelular, caracterizada por alto grau de conservação estrutural na sua sequência de aminoácidos e estrutura 3D [20,21].

A superfamília de proteínas $\mathrm{S} 100$ foi primeiramente isolada em cérebro bovino [22]. Em decorrência de sua abundância nesse tecido, inicialmente, se achou que estaria restrita ao sistema nervoso central (SNC). No entanto, desde 1981, sabe-se que além de não estarem restritas ao SNC, podem ser encontradas no sistema nervoso periférico e em tecidos que não sejam de origem nervosa [23]. Desde então, centenas de artigos científicos descreveram a localização das proteínas S100 em diferentes tecidos [24] e, nos dias de hoje, elas se tornaram um importante instrumento de pesquisa e diagnóstico em biologia e patologia bucal [25].

Estudos realizados na década de 90 [26] descobriram que existe 2 tipos de proteínas S100 - S100A e S100B - e, subseqüente a estes trabalhos, descobriu-se que existe cerca de 21 sub tipos dessas proteínas distribuídos dentro desses 2 grandes grupos [26-29].

As proteínas do tipo S100 não têm funções enzimáticas conhecidas e parecem agir intracelularmente através de interações com alvos específicos. Alterações nas suas funções podem ter implicação direta em num grande número de doenças, incluído o câncer, a Síndrome de Down, a Síndrome de Alzheimer, cardiomiopatias, psoríase, fibrose cística, epilepsia, entre outras [26, 30, 31]. 
$\underline{\text { Nestin }}$

A habilidade das células em adotar uma variedade de formas e de direcionarem e coordenarem os seus movimentos depende do seu citoesqueleto; uma complexa rede de filamentos que se estendem através do seu citoplasma [32]. Neste contexto, a proteína nestin foi caracterizada como um filamento intermediário do tipo IV [33] e sua expressão pode ser evidenciada nas fases iniciais do desenvolvimento do sistema nervoso central e músculos esqueléticos [34, 35]. É ainda apontada por alguns autores como restrita a progenitores celulares nesses tecidos [36, 37] ou, mais especificamente, característica de células-tronco neurais, ao menos no sistema nervoso central [38].

Estudos prévios já demonstraram a presença dessa proteína no decorrer do desenvolvimento dental e relatando que ela exibe um complexo padrão de expressão, diferindo a sua distribuição em tempo (ao longo da odontogênese) e espaço (ora em células epiteliais, ora em mesenquimais). Nas células epiteliais a expressão de nestin é geralmente evidenciada, fracamente, nos ameloblastos e células do extrato intermediário durante a fase de campânula do desenvolvimento dental. A medida que o dente continua o seu desenvolvimento, a expressão de nestin não pode mais ser evidenciada nos derivados ectodérmicos. Em contraste, a expressão de nestin é aumentada nas células mesenquimais quando o germe dental está mais desenvolvido. Neste caso, a proteína pode ser evidenciada nos odontoblastos e nos seus prolongamentos citoplasmáticos que, por vezes, adentram aos túbulos dentinários [32].

Em suma, parece que a nestin pode ser utilizada tanto para identificação de tecido nervoso em fases iniciais de desenvolvimento quanto para a identificação de células bem diferenciadas ao longo do desenvolvimento dental, especificamente os odontoblastos, neste caso [32]. 


\subsection{Formação do sistema vascular da polpa dental durante a odontogênese}

O desenvolvimento do sistema vascular no organismo humano se dá através dos processos de vasculogênese ou de angiogênese. Quando o processo de desenvolvimento vascular decorre da diferenciação de progenitores endoteliais, chama-se vasculogênese $[39,40]$. Já quando os vasos sanguíneos se desenvolvem a partir de vasos sanguíneos pré-existentes, chama-se angiogênese [41]. Neste contexto, durante o desenvolvimento embrionário, as células endoteliais podem se originar de precursores que podem produzir apenas células endoteliais (angioblastos), ou ainda de progenitores que podem dar origem tanto as células endoteliais quanto as do sistema hematopoiético (hemangioblastos) [42]. Em tecidos adultos, novos vasos geralmente se originam por angiogênese, embora a vasculogênese também possa ocorrer [42].

Embora as células endoteliais pareçam ocupar o centro das atenções quando o assunto é desenvolvimento do sistema vascular, elas, sozinhas, podem iniciar, mas não completar o processo de angiogênese; células perivasculares, também chamadas de células murais ou da musculatura lisa, são essenciais para a maturação vascular [42].

As células da musculatura lisa dão estabilidade aos vasos em formação por inibirem a proliferação e a migração das células endoteliais e por estimularem a produção de matriz extracelular por estas. Adicionalmente, em fases mais avançadas de desenvolvimento vascular, além de protegerem os vasos contra ruptura, também controlam o fluxo sanguíneo em decorrência da sua capacidade de contração [42].

Desta forma, fica claro que os vasos sanguíneos são compostos por dois principais tipos celulares: as células endoteliais que, ao alinharem-se, formam a parte interna dos vasos $\mathrm{e}$; as células da musculatura lisa que se localizam externamente às endoteliais [43]. No que concerne as suas origens, sabe-se que as células endoteliais se originam de células mesodérmicas Flk1 positivas [44], 
enquanto que as da musculatura lisa podem se originar da mesoderme, crista neural ou epicárdio [45-47].

Além das células da musculatura lisa, outros tipos celulares comumente envolvem os vasos sanguíneos. A quantidade e o tipo de células que circundam os vasos varia de acordo com o tipo de sistema vascular [48]. No sistema circulatório do coração, por exemplo, várias camadas de células de músculo liso circundam os vasos próximais enquanto que células isoladas (não agrupadas em camadas), conhecidas como pericitos, recobrem os vasos menores e mais distantes da musculatura cardíaca [43]. Pericitos são células que tem sido largamente estudadas e já se sabe que a interação entre as células da musculatura lisa, os pericitos e as células endoteliais é essencial para o desenvolvimento e manutenção do desenvolvimento vascular na grande maioria dos sistemas [42, 49].

Os pericitos são células multipotentes, comprovadamente capazes de se diferenciar em células musculares, adiposas, condro e osteoblásticas [50, 51]. São células perivasculares multifuncionais, polimórficas e que, entre outras coisas, contribuem para a produção da lâmina basal de pequenos vasos e localizam-se na porção abluminal do endotélio de tal forma que uma única célula recobra imparcialmente várias outras [52].

O tipo de contato que os pericitos têm com as células endoteliais é bastante variável [53]. Comumente, envolvem os vasos sanguíneos similarmente a um guarda-chuva, controlando a abertura das junções endoteliais [54].

Em circunstâncias onde a pressão arterial é elevada, o primeiro local de extravasamento se dá por entre as junções endoteliais [55]. Neste sentido, já foi analisado que a proporção de pericitos em relação ao número de células endoteliais está diretamente relacionada ao quão fortalecida estão as junções inter-endoteliais e ao quão elevada é a média de pressão arterial [56]. Logo, conclui-se que também possuem um importante papel no controle da pressão arterial e na homeostase sanguínea.

Os pericitos estão ganhando uma importância tão grande no contexto dos estudos sobre vascularização que já se sabe que quando os vasos os perdem, ficam hemorrágicos e hiperdilatados, conduzindo, desta forma, a condições de edema, 
retinopatia diabética e, até mesmo, morte embrionária [57]. Dada a importância dessas células, é imprescindível o seu estudo.

No contexto de estudo dos processos de vasculo e/ou angiogênese - seja na polpa dental ou em outros tecidos - pode-se alçar mão de vários imunomarcadores. Dentre eles, podemos citar:

\section{$\underline{\text { Fator vascular de crescimento endotelial (VEGF) }}$}

O VEGF é uma subfamília de proteínas pertencente a classe dos fatores de crescimento. Ele compreende um montante importante de proteínas envolvidas tanto na vascuologênese ("nova" formação do sistema circulatório do embrião) quanto na angiogênese (crescimento de vasos sanguíneos a partir de vasos préexistentes) [58].

A presença de VEGF pode ser evidenciada tanto nas células endoteliais [59] quanto nas células da musculatura lisa perivasculares [60] e pericitos [61].

Ademais, já foi provado que a maioria dos precursores endoteliais encontrados em adultos é capaz de se diferenciar in vitro em resposta ao fator de crescimento VEGF e, estudos mais recentes, têm considerado este grupo de fatores de crescimento como um marcador de vasos sanguíneos em fases iniciais de desenvolvimento [62].

$\mathrm{Na}$ polpa dental, o VEGF é expresso constitutivamente pelos vasos sanguíneos [63] e pode ainda ser encontrado na matriz dentinária [64].

\section{$\underline{\text { CD105 (endoglin) }}$}

A CD105 é uma glicoproteína homodimérica de membrana que se combina ao fator de crescimento- $\beta 1$ (TGF- $\beta 1$ ) e TGF- $\beta 3$ [65] e é usualmente expressa em vasos sanguíneos em desenvolvimento durante a angiogênese [66-69].

Quando utilizado com o propósito de identificar neoangiogênese, a CD105 tem mostrado algumas vantagens sobre outros conhecidos imunomarcadores 
endoteliais (CD31, CD34 e Fator VIII). O anticorpo anti-CD105 se liga preferencialmente a células endoteliais ativadas [70].

Recentemente, muitos estudos que têm investigado a expressão de CD105 em câncer endometrial [71], câncer cervical [70], câncer de mama [72], câncer coloretal [66] e câncer de cabeça e pescoço [73] relatam que esse imunomarcador tem se mostrado mais sensível para evidenciação de neovascularização que os demais.

\section{Actina de músculo liso (AML)}

A AML está presente nos músculos lisos, que são um tipo de musculatura encontrada na túnica média de pequenos e grandes vasos sanguíneos [74, 75].

Como abordado anteriormente, células da musculatura lisa perivascular podem ter diferentes origens, de acordo com a sua localização. De uma maneira geral elas podem se transdiferenciar de células endoteliais ou se diferenciar de células mesenquimais, incluindo as da medula óssea [42].

As células da musculatura lisa dão suporte estrutural aos vasos sanguíneos de uma maneira geral e, especificamente para as arteríolas, são importantes para o controle do fluxo sanguíneo em decorrência da sua capacidade de contração [76].

Apesar das células da musculatura lisa envolverem as células endoteliais, elas não estão em contato direto com estas; estão separadas das células endoteliais por uma membrana basal e, em grandes artérias, por um tecido chamado íntima [76]. A título de comparação, os pericitos estão diretamente em contato com as células endoteliais, compartilhando de uma mesma membrana basal com estas células [77]. 
O proteoglicano NG2 é um componente da superfície celular expresso tanto pela vasculatura formada pelos processos de vasculogênese quanto de angiogênese. Durante o desenvolvimento normal do organismo, o NG2 é encontrado em grandes vasos formados por vasculogênese, como o caso da aorta, por exemplo [78], e em microvasos formados por angiogênese, como os presentes no sistema nervosos central, por exemplo $[79,80]$. Além disso, o NG2 também pode ser encontrado na microvasculatura associada a tumores ou a processos cicatriciais [81, 82]. Um ponto em comum entre todos esses estudos é a constatação da superexpressão de NG2 em neovasos e da hipoexpressão em vasculaturas quiescentes.

Um ponto que por muito tempo apresentou-se contraditório na literatura é se tanto as células da musculatura lisa quanto os pericitos poderiam expressar NG2. De maneira geral, em macrovasculaturas o NG2 deve ser considerado como um importante suplemento a lista dos imunomarcadores conhecidos para células da musculatura lisa. Já, na microvasculatura, o NG2 parece ser um dos melhores marcadores utilizados para estudar o desenvolvimento de pericitos [83].

\section{Receptor $\beta$ do Fator de Crescimento Derivado de Plaquetas (PDGFR- $\beta$ )}

O subtipo beta $(\beta)$ do receptor do fator de crescimento derivado de plaqueta é uma proteína tirosino-kinase da família de receptores derivados de plaqueta [84].

Fortes evidências sugerem que o PDGFR- $\beta$ possui um papel crucial no recrutamento dos pericitos para a formação de novos vasos. A ausência de PDGFR$B$ em camundongos geneticamente modificados implica em mortalidade perinatal por rompimento da microvasculatura $[85,86]$. A causa da disfunção vascular nesses camundongos é devido a uma deficiência severa na formação de pericitos [85]. 
Durante a angiogênese, o PDGFR- $\beta$ é expresso tanto por células da musculatura lisa quanto pelos pericitos $[74,85]$, o que sugere um modelo parácrino de interação entre esses dois grupos celulares [76]. Outros estudos também corroboram com estas especulações. Em quimeras compostas por células PDGFR- $\beta$ positivas e negativas apenas as células PDGFR- $\beta$ positvas foram capazes de povoar os compartimentos condizentes com as das células de musculatura lisa e dos pericitos, demonstrando que ambas populações são diretamente dependentes do PDGFR- $\beta$ pra se desenvolverem [87].

\subsection{Engenharia tecidual dental}

O conceito de engenharia tecidual surgiu com Langer (1993) definindo-a como "um campo interdisciplinar da ciência que faz uso de princípios da engenharia e ciências biológicas para desenvolver substitutos para as estruturas biológicas capazes de restaurar, manter ou melhorar a função de um tecido" [88].

Neste nicho de pesquisa - a engenharia tecidual - os dentes apresentam duas grandes vantagens sobre os demais órgãos do organismo: são acessíveis e não essenciais para a vida [89]. Além disso, descobriu-se recentemente que existem diferentes tipos de células-tronco nos diversos tecidos dentais, úteis não só para reparação e regeneração de estruturas dentais [90-94], mas também para recuperar áreas perdidas ou danificadas de outros órgãos ou tecidos do corpo [91, 93, 95-97].

Dentre as células-tronco dos tecidos dentais, destacam-se as células-tronco da polpa dental, as quais já demonstraram capacidade de formar um material análogo a dentina, tecido adiposo e de expressar proteínas de tecido nervoso, como a nestin, por exemplo [98]. Neste mesmo sentido, outros estudos já demonstraram que, tanto na dentição permanente quanto na decídua, o tecido pulpar contem células-tronco [99-102], e que estas apresentam propriedades diferentes [101, 102]. As células-tronco obtidas da polpa de dentes permanentes têm a capacidade 
inata de formar - quando inoculadas subcutaneamente em camundongos imunocompremetidos - um tecido dentinóide e osso; já as células-tronco provenientes do tecido pulpar de dentes permanentes conseguem formar um complexo dentino-pulpar, mas não tecido ósseo [100, 101].

Haja vista os avanços nas pesquisas com células-tronco dentais e engenharia de tecidos e o anseio por se construir um biodente capaz de substituir ou repor as estruturas dentais e peridentais perdidas ou ausentes, em sua plenitude, destacam-se duas formas de se construir um biodente: criar um molde com o formato do dente que se quer construir e colocar sobre ele células capazes de formar os tecidos dentais $[2,103]$, ou tentar reproduzir in vitro o processo de formação de um dente tal qual ele ocorre desde o início do desenvolvimento do embrião - onde o desenvolvimento dental se dá pela interação entre o tecido epitelial e ecto mesenquimal - para então posterior transplante in vivo [3]. Tais técnicas são melhor explicadas a seguir:

\section{Técnica do uso de moldes}

Na odontologia, essa técnica foi primeiramente usada por Young (2002) que, em conjunto com seus colaboradores, confeccionou moldes de polímeros biodegradáveis feitos com materiais biocompatíveis, a exemplo do poliglicolato/poliL-lactato (PGA/PLLA) e do poli-L-lactato-co-glicolato (PLGA)). Sob esses moldes foram colocadas células provenientes de germes dentais dissociados enzimaticamente e, então, o conjunto células/molde foi mantido em cultivo durante 6 dias. Subsequentemente a este, o conjunto células/moldeira foi colocado no omento de ratos imunocomprometidos com a finalidade de que estas células tivessem um lugar propício para o seu desenvolvimento (como um bom aporte sanguíneo, por exemplo). Após 20-30 semanas, analises histológicas revelaram a formação de pequenas coroas dentais $(1-2 \mathrm{~mm})$ com evidente formação de esmalte, dentina e polpa dental [2]. 
Em 2008, o mesmo grupo de pesquisadores supracitado [104], após tentativas prévias [103], conseguiram aprimorar suas técnicas e atingir um importante objetivo: criar não só uma coroa dental, mas, além dela o início da formação de uma raiz com ligamento periodontal [104]. Esse foi mais um importante passo já que, em 2009, conseguiu-se formar também cemento e osso alveolar [105]. Estudos como esses mostram a capacidade que as células epiteliais e ectomesenquimais têm de se auto-reagregarem e de se diferenciarem.

A pesar dos achados promissores, a técnica do uso de moldes ainda apresenta alguns problemas que, conseqüentemente, a distanciam da aplicabilidade clínica por enquanto: até o presente momento os dentes formados não assumem fielmente o formato dos moldes e, além disso, as molduras são um modelo estático de desenvolvimento enquanto que os dentes apresentarem um modelo dinâmico de formação. As células odontogênicas sofrem mudanças citomorfogenéticas ao longo do desenvolvimento dental e o dente sofre mudanças em sua estrutura durante toda a sua vida; as molduras não acompanham tais modificações.

\section{Técnica da recombinação tecidual}

Esta técnica objetiva reproduzir o desenvolvimento dental tal qual ele ocorre durante a odontogênese [106]. Pra isso, leva-se em consideração o que já se é de senso comum: o processo de formação dental é fruto de uma série de interações recíprocas entre um epitélio odontogênico e o ectomesênquima subjacente [107]. $O$ tecido epitelial dará origem aos ameloblastos enquanto que 0 mesenquimal a dentina, polpa, ligamento periodontal e demais tecidos de suporte. Nesse sentido, a idéia da técnica de recombinação tecidual consiste, portanto, em fazer o uso de fontes celulares epiteliais e mesenquimais capazes de interagir entre si e formar cada um dos tecidos dentais, mimetizando o que ocorre naturalmente durante a odontogênese [106]. 
Até 0 presente momento, as fontes epiteliais mais usadas provêm de epitélio odontogênico da lâmina dental de embriões de ratos e camundongos e, o tecido mesenquimal, do próprio ectomesênquima subjacente ao epitélio odontogênico ou de outras fontes de células mesenquimais como, por exemplo, a medula óssea [106, 108-110].

A recombinação de tecidos dentais ganhou destaque no cenário científico mundial no ano de 2004 quando a equipe britânica de pesquisadores chefiada pelo Professor Paul Sharpe [106] revelou que tanto células odontogênicas quanto as não odontogênicas (medula óssea) podem formar tecidos odontogênicos nos experimentos de recombinação tecidual. Desde então, a técnica veio sendo aprimorada por este e por outros grupos de pesquisa [108, 109, 111] culminando hoje na formação de um dente que não só é composto por todos os tecidos dentais e peridentais, mas que também é dotado de capacidade eruptiva, resistência mecânica e passividade para movimentação ortodôntica similares aos dentes naturais [110].

Um dos principais desafios da técnica de recombinação tecidual consiste em se achar substitutos celulares viáveis como fontes alternativas para o uso das células epiteliais e mesenquimais. No caso das células mesenquimais, já se sabe, que podem ser substituídas por células de medula óssea, por exemplo [106]. O maior problema ainda consiste então em não ter sido encontrado um substituto biológico para o epitélio odontogênico, uma vez que este ainda só é obtido da lâmina dental da cavidade bucal de embriões (estudos feitos apenas em animais até o presente momento). Outro grande impasse dessa técnica é controlar a forma do biodente. A dentição humana é composta por dentes com diferentes formas, se destacando quatro principais: os incisivos, os caninos, os pré-molares e os molares. Além disso, há de se dizer que os dentes de um quadrante não são iguais aos do lado contralateral e, muito menos, aos da arcada oposta, ou seja, não basta apenas saber como desenvolver um desses órgãos; precisa-se ao menos de 16 principais diferentes morfologias pra se formar uma dentição completa. 
O vigente conceito sobre engenharia tecidual dental é, portanto, inerente a uma técnica de regeneração tecidual natural que pode ser reproduzida in vitro [112]. Nesse mesmo sentido, o interesse na aplicação das novas técnicas de engenharia tecidual na medicina e odontologia regenerativas cresce exponencialmente a cada ano [89].

Como abordado, estudos recentes mostram que é possível criar biodentes quando condições mínimas pra tal são oferecidas. Independentemente da técnica utilizada, geralmente usa-se um sítio ectópico pós-cultura do órgão do esmalte in vitro para que ele prossiga com o seu desenvolvimento antes de ser transplantados definitivamente para o seu sítio anatômico. A exemplo desses locais transitórios de manutenção do germe dental podemos citar a cápsula renal [106], a cavidade abdominal [103], a câmera anterior do olho [113], a membrana córion-alantóide de aves [114], o tecido subcutâneo [109] e o osso alveolar [110]. Experimentalmente, esses sítios de cultivo parecem prover os nutrientes e o oxigênio necessários para o desenvolvimento dos germes dentais durante o período de tempo que permanecem nestes locais [112] mas, ainda não se sabe até que ponto podem influenciar de fato no desenvolvimento dental.

Será que a escolha deste sítio é determinante para um melhor desenvolvimento dental? Será que resultará em um dente com forma e função mais aprimorados? Será que pode influenciar na formação de estruturas vitais dos biodentes tais quais a tecido nervoso e vascular? Essas e outras perguntas ainda não estão bem esclarecidas na literatura e fazem necessária a realização de novas pesquisas. 
Proposição 


\section{PROPOSIÇÃO}

O presente trabalho teve por objetivo:

- Avaliar se o desenvolvimento nervoso e vascular de um germe dental transplantado é afetado em decorrência do estágio de desenvolvimento dental que ele se encontra no momento do transplante.

- Avaliar se a presença ou ausência de tecido ósseo no sítio ectópico de transplante de um germe dental pode influenciar o padrão de formação do tecido vascular e nervoso no mesmo.

- $\quad$ Avaliar se a posição de implantação do germe dental pode influenciar o padrão de formação vascular e nervosa do dente implantado. 
Materiais e Métodos 


\section{MATERIAIS E MÉTODOS}

Esta pesquisa foi aprovada pelo Comitê de Ética em Pesquisa, subcomissão de Experimentação Animal, da Faculdade de Odontologia da Universidade de São Paulo, conforme parecer de aprovação número 05/09 (Anexo A).

Os animais foram procedentes do biotério do Instituto de Ciências Biomédicas da Universidade de São Paulo e a experimentação com os mesmos só se deu após aprovação do Comitê de Ética em Pesquisa, subcomissão de Bioética em Animais, da Universidade de São Paulo, conforme acima nomeado.

\subsection{Obtenção das amostras}

O objeto de estudo da presente pesquisa restringiu-se a germes dentais de primeiros molares superiores de ratos Wistar com 2 e 6 dias de vida pós-natal bem como de ratos machos, da mesma raça, em fase adulta (6-8 semanas de vida pósnatal).

A motivo da escolha para se trabalhar com os germes dentais de ratos com 2 e 6 dias de vida pós-natal especificamente se deu em virtude de os dentes dos primeiros molares superiores dos animais com 2 dias de vida terem uma vascularização insipiente na polpa dental e terminações nervosas apenas começando a emergir para o tecido pulpar e, já com 6 dias de vida, os primeiros molares superiores já terem uma vascularização e inervação consistentes no tecido pulpar.

Para a análise da vascularização e inervação de germes dentais transplantados, o primeiro passo foi a obtenção dos germes a serem transplantados. Para isso, os germes dentais dos primeiros molares superiores 
foram extraídos dos animais com 2 e 6 dias de vida, respectivamente. Para a realização das exodontias, os animais foram sacrificados por deslocamento cervical seguido de decapitação. Em seguida, prosseguiu-se a desinfecção das cabeças com álcool $70 \%$ e a transferência das mesmas para uma Placa de Petri estéril. Nesta, e com a ajuda de um estereomicroscópio (marca ZEIZZ, modelo Stemi SV 11) que proporcionava uma amplificação de imagem de 10x, seguiu-se a dissecção mecânica da maxila direita e esquerda e extração bilateral dos germes dentais dos primeiros molares. Imediatamente após a exodontia dos germes, eles eram transferidos para uma outra Placa de Petri estéril contendo solução de PBS com 2\% de solução de antibióticos e antimicóticos (penicilina $10.000 \mathrm{UI} / \mathrm{ml}$; estreptomicina $10 \mathrm{mg} / \mathrm{ml}$ e anfotericina B 25 $\mathrm{\mu g} / \mathrm{ml}$; SIGMA, \# A5955) onde permaneciam por $2 \mathrm{~min}$. Após, eram transferidos para uma outra Placa de Petri estéril, contendo meio de cultura Duldeco's Eagle Modified Meadium (SIGMA, \# D6429) com 10\% em volume de soro fetal bovino (GIBCO, \# 12657-029) e $2 \%$ de solução de antibióticos e antimicóticos (penicilina, estreptomicina e anfotericina B), onde permaneciam durante o trans operatório dos animais adultos, até que estes estivessem em condições de recebê-los como implantes.

Conforme será visto mais adiante, os germes foram transplantados, em um grupo de animais, sob a cápsula renal e, em outro grupo, dentro da tíbia direita e esquerda. Para a realização dessas cirurgias de transplante, os animais adultos foram previamente anestesiados por via intramuscular com solução do anestésico cloridrato de xilazina (Anasedan ${ }^{\circledR}$ ) e de relaxante muscular a base de cloridrato de ketamina (Dopalen ${ }^{\circledR}$ ), na proporção $1: 1$ e na dose de $1 \mathrm{ml} / \mathrm{Kg}$ do animal.

Para ter acesso aos rins, após decorrido o tempo de indução anestésica, o dorso dos animais era tricotomizado com giletes e desinfectado com solução anticéptica (Polvidine ${ }^{\circledR}$ ). Após, uma incisão de $2 \mathrm{~cm}$ era feita sob a linha mediana do dorso, em sentido sagital, seguida de divulsão dos tecidos. Na região de cada um dos rins (a aproximadamente $6,5 \mathrm{~cm}$ para a posterior das orelhas do animal no sentido caudal) fazia-se uma incisão de $1 \mathrm{~cm}$ na camada muscular utilizando-se uma lâmina de bisturi de aço inoxidável estéril, número 11 (Free-Bac, \# 7474) e, com a ajuda de instrumentos cirúrgicos estéreis, o rim era acessado, a cápsula renal era distendida, perfurada e, através desta perfuração, os germes eram 
introduzidos sob a cápsula renal. Por fim, os rins eram reposicionados na cavidade abdominal e seguia-se com a sutura da camada muscular e epitelial, respectivamente, utilizando-se fios de sutura nylon $3 / 0 \mathrm{com}$ agulha de $20 \mathrm{~mm}$ (Procare ${ }^{\circledR}$ ).

Para o implante dos germes dentais nas tíbias, após dado o tempo de indução anestésica, ambas as patas traseiras dos animais eram tricotomizadas com giletes e desinfectadas com solução anticéptica (Polvidine ${ }^{\circledR}$ ). Após, uma incisão de $2 \mathrm{~cm}$ era feita na região anterior da pata, em sentido sagital e os tecidos eram divulsionados para se ter acesso ao osso tíbia. Neste momento, com a ajuda de uma broca esférica cirúrgica (KG Sorensen, $\mathrm{n}^{\circ} 4$ ) montada em um micromotor odontológico do tipo contra-ângulo e sob constante irrigação com solução de PBS acrescida de antibióticos e antimicóticos já descritos anteriormente (2\% de concentração) fora realizada uma perfuração na face medial de cada uma das tíbias, com diâmetro e profundidades precisamente semelhantes aos dos germes a serem implantados no local. Feito as perfurações, o local era lavado com $2 \mathrm{ml}$ de PBS com $2 \%$ de solução de antibióticos e antimicóticos e limpado com gazes estéreis. Findada a implantação dos germes, o tecido muscular era reposicionado sob a tíbia e o couro da pata era suturado com fio de nylon $3 / 0$ e agulha $20 \mathrm{~mm}$ (Procare ${ }^{\circledR}$ ).

\subsection{Avaliação do desenvolvimento nervoso e vascular nos germes dentais transplantados}

A primeira instância foi analisado o desenvolvimento dos primeiros molares superiores em um grupo controle de ratos da raça Wistar com idade variando desde recém-nascidos até do décimo sétimo dia de vida pós-natal. 0 intuito desses experimentos era comparar o desenvolvimento dental in loco durante a cronologia natural de desenvolvimento desses dentes para ter um parâmetro de comparação do quão afetado poderia ter sido o desenvolvimento dos germes dentais com 
mesmo tempo de desenvolvimento, após terem sido transplantados sob diferentes condições.

O grupo experimental foi composto por 36 ratos machos da raça Wistar em fase adulta de vida (6-8 semanas). Estes animais foram divididos em dois grandes grupos: GRUPO R, animais que receberam o transplante dos germes dentais sob a cápsula renal e; GRUPO T, animais que tiveram os germes dentais implantados nas tíbias. Os grupos $\mathbf{R}$ e $\mathbf{T}$ foram igualmente subdivididos em grupos menores: R1 e R2; e T1 e T2 respectivamente, seguindo os seguintes critérios:

- Grupos R1 e T1: cada um destes grupos fora composto por 9 ratos que receberam o transplante de germes dentais de primeiros molares superiores de animais com 2 dias de vida pós-natal sob a cápsula renal e tíbia, respectivamente.

- Grupos R2 e T2: cada um destes grupos fora composto por 9 ratos que receberam o transplante de germes dentais de primeiros molares superiores provenientes de animais com 6 dias de vida pós-natal sob a cápsula renal e tíbia, respectivamente.

Vale ressaltar que a posição de implantação dos germes sob a cápsula renal não seguiu critério algum uma vez que este sítio anatômico não permite tal escolha mas, em contrapartida, os germe dentais implantados nas tíbias receberam sempre: na tíbia direita, os germes dentais com o forame apical voltado para o interior do espaço medular da tíbia e, na tíbia esquerda, com o forame apical voltado para o periósteo.

Decorridos 3, 7 e 11 dias das cirurgias de transplante dos germes dentais, 3 animais de cada um dos grupos (R1, T1, R2 e T2) foram sacrificados por sedação com $\mathrm{CO}_{2}$ seguida de deslocamento cervical. Após o sacrifício, realizou-se, no GRUPO R, a extração dos rins e dissecção dos germes dentais neles transplantados e, no GRUPO T, extração das tíbias direita e esquerda. 


\subsubsection{Fixação e processamento histotécnico}

O material experimental extraído dos animais foi, imediatamente, fixado em solução de paraformoldeído 4\% (marca Labsynth, \# 00P1004.08.AG), glutaraldeído 0,1\% (SIGMA, \# G5882) e tampão cacodilato (SIGMA, \# C-0250) por período de $24 \mathrm{~h}$, a $4^{\circ} \mathrm{C}$. Após, os espécimes receberam 6 banhos de 10 min cada com solução de tampão cacodilato e água deionizada nas proporções 1:1 pra remoção da solução fixadora e hidratação do material. A descalcificação seguiu-se em solução de EDTA 4,13 \% (marca Labsynth, \# S3170) por 5 a 10 dias para os germes que se desenvolveram nos rins e por volta de 40 dias para as tíbias que continham os germes no seu interior. A solução de EDTA era trocada a cada 2 dias, permaneceu em temperatura ambiente e sob constante agitação.

Após o período de descalcificação, as amostras foram desidratadas com banhos de álcool $30^{\circ}\left(5 \mathrm{~min}\right.$ ), álcool $50^{\circ}$ (5 min) e $70^{\circ}$ (pelo tempo mínimo de $1 \mathrm{~h}$ e máximo de 24h). O restante do processamento histotécnico do material, cuja finalidade era incluí-lo em parafina, se deu de forma automatizada utilizando-se pra isso o aparelho da marca SACURA, modelo RH-12E, conforme descrito no Apêndice A.

Do material histológico emblocado em parafina, foram obtidos cortes histológicos seriados com $3 \mu \mathrm{m}$ de espessura em micrótomo da marca Leica (modelo RM 2045) e com navalhas próprias para cortes histológicos da marca EasyPath. Os cortes foram dispostos sob gotas de água deionizada colocadas de maneira organizada, com a ajuda de uma pipeta, sob lâminas histológicas de vidro (26mmx76mm) próprias para microscopia de luz (marca Precision, \# 7105). A posição que cada gota e, por conseguinte, que cada corte iria ocupar em cada lâmina seguiu os critérios descritos no Apêndice B. Após a colocação dos cortes em seus devidos lugares, as lâminas seguiram para uma estufa a $60^{\circ} \mathrm{C}$ onde permaneceram por um tempo aproximado de $2 \mathrm{~h}$. Neste momento, as gotículas de água se aqueciam, os cortes histológicos parafinados se distendiam e, a medida que a água evaporava, os cortes repousavam e aderiam sob a lâmina histológica, permanecendo esticados e na posição predeterminada pela gota de água. As 
lâminas da primeira série de cada bateria (exemplo, A1, B1, C1, D1 e E1) seguiram sempre para coloração com Hematoxilina de Harris e Eosina Alcoólica (HE). Tal coloração foi realizada de forma automatizada em aparelho Tissue-Tek DRS da marca SACURA (EUA) conforme descrito no Apêndice $C$.

Após análise histológica de todas as baterias, escolhia-se qual delas continha o melhor grupo de cortes histológicos (aqueles que continhas as porções mais centrais dos germes dentais). Somente estes seguiam para análise imunoistoquímica. Por exemplo, se as baterias $\mathrm{A}$ e $\mathrm{C}$ compreendiam as porções extremas dos tecidos (início e fim do dente cortado) e a bateria $B$ compreendia um montante de amostras com a melhor qualidade tecidual, seguiram para análise imunoistoquímica apenas as lâminas da bateria B (exemplo, B2, B3, B4 e B5) uma vez que possivelmente iriam representar de melhor maneira o montante de tecido cortado, em diferentes níveis de profundidade. Por fim, cada lâmina foi submetida a reações de imuniistoquimica para apenas um anticorpo primário.

\subsubsection{Reação de imunoistoquimica}

Todas as reações foram realizadas pela técnica da imunoperoxidase e seguiram-se separadamente utilizando os respectivos anticorpos: anti-S100 (polyclonal rabbit anti-S100, Dako, \# Z0311); anti-actina de músculo liso (AML) (monoclonal mouse [1A4] anti-human smooth muscle actin, Dako, \# M0851), antiNG2 (mouse monoclonal [132.38] anti-NG2, Abcam, \# 50009); anti-nestin (mouse monoclonal [2Q178] anti-nestin, Lab Supplay Mall, \# 8-6142), anti-VEGF (mouse monoclonal [JH121] anti-VEGF, Lab Supplay Mall, \# 8-28775), anti-CD105 (purified rat anti-mouse CD-105, BD Pharmingen, \# 550546) e anti-PDGFR- $\beta$ (rabbit monoclonal [Y92] to PDGF receptor beta, Abcam, \# 32570-100).

As lâminas histológicos selecionados para as reações de imunoistoquímica foram desparafinizados em banho de Xilol (I) a $60^{\circ} \mathrm{C}$ por $30 \mathrm{~min}$ e em Xilol (II) a temperatura ambiente, por 15 minutos. A seguir, foram reidratados em cadeia descendente em concentração de etanol (álcool absoluto I, álcool absoluto II, álcool 
absoluto III, álcool 95\%, 90\%, 85\% e $80 \%$ ) durante 3 minutos cada. Após a reidratação, foi realizada a remoção do pigmento formólico através de incubação em hidróxido de amônia a 10\% em solução alcoólica (etanol 95\%), por 5 minutos. Após, 2 lavagens em água destilada, por 5 min cada, as lâminas receberam o tratamento para recuperação antigênica (excetuando-se as lâminas que receberiam o anticorpo primário anti-S100 e anti-nestin). Para tal, as lâminas que receberiam os anticorpos primários anti-AML, anti-CD105 e anti-PDGFR- $\beta$ foram totalmente imersas em solução de ácido cítrico $10 \mathrm{mM}$, pH 6,0 e colocadas em banho de água aquecida a $95^{\circ} \mathrm{C}$, durante 30 minutos.

Ao final do tratamento de recuperação antigênica, os cortes foram imediatamente lavados com solução de TRIS pH 7,6 (2 lavagens de 10 min cada). Em seguida, tanto as lâminas que passaram pelo processo de recuperação antigênica quanto as que não o necessitaram, seguiram para a etapa de bloqueio da peroxidase endógena tecidual, incubando-se as lâminas em solução de peróxido de hidrogênio a $6 \%$ e metanol na proporção $1: 1$, em dois banhos de 15 minutos cada. Os cortes receberam então 3 banhos de TRIS pH 7,6 por 5 min cada e, em seguida, seguiram para o bloqueio de sítios inespecíficos com solução de BSA. Esta solução - composta por soluções de albumina bovina, azida sódica e TRIS - foi colocada com a ajuda de uma pipeta, em quantidade suficiente para recobrir os cortes histológicos, e permaneceu em contato com os tecidos por 30 minutos. Após, repetiram-se 3 lavagens com solução de TRIS pH 7,6 por 5 minutos cada.

Os anticorpos primários foram diluídos em BSA nas proporções de 1:1200 para o anticorpo anti-S100, 1:200 para o anti-AML, 1:200 para o anti-nestin e 1:50 para os anticorpos anti-CD105, anti-VEGF, anti-NG2 e anti-PDGFR-B.

O tempo de incubação dos anticorpos primários anti-S100 e anti-AML foi de $1: 30 \mathrm{~h}$, em temperatura ambiente, e para todos os demais foi de aproximadamente $16 \mathrm{~h}$, a $4^{\circ} \mathrm{C}$.

Após o uso dos anticorpos primários anti-S100, anti-AML, anti-nestin, antiNG2 e anti-PDGFR-ß foi utilizado o Kit LSAB (Dako, \# k0690) conforme instruções do fabricante. Esse sistema de marcação é baseado na técnica da avidina-biotina, na qual um anticorpo secundário biotinizado reage com várias moléculas de streptavidina-peroxidase conjugada. 
Já, após o uso dos anticorpos primários anti-CD105 e anti-VEGF, foi utilizado o sistema ADVANCE HRP (Dako, \# k4068) de detecção. Este sistema é biotina free e é mais sensível que o do Kit LSAB. Consiste basicamente em um anticorpo de ligação e uma enzima HRP polimerizada a uma peroxidase. Por essas propriedades, é recomendado principalmente para os casos onde o antígeno está presente em baixas concentrações ou quando há muita marcação inespecífica.

Todas a reações foram reveladas pelo sistema cromógeno DAB (DAKO, \# k3468) que faz uso do corante 3,3'-diaminobenzidina e é indicado para as reações de imunoistoquimica pela técnica da peroxidase, uma vez que, na presença desta enzima, produz um precipitado acastanhado e torna a imunoreação visível à microscopia de luz.

Finalizada essa etapa, os cortes histológicos foram contracorados com Hematoxilina de Mayer (LAFAN, \# 15772), lavados rapidamente em imersões de água, desidratados em soluções com concentrações crescentes de etanol $(50 \%$, $60 \%, 70 \%, 80 \%$, 90\%, 95\%, 100\%, 100\% e 100\%), diafanizados em 2 banhos de xilol (5 min cada) e montados automatizadamente (SAKURA, Tissue-Teck ${ }^{\circledR}$ SCA).

Como controle positivo das amostras, foram utilizados cortes histológicos de língua de rato, tecido este ricamente inervado e vascularizado.

\subsubsection{Análise de resultados}

As lâminas foram observadas em microscopia de luz. A expressão imunoistoquímica foi analisada de forma semi-quantitativa, considerando positivas as células que exibiram coloração acastanhada após a reação imunoistoquimica e consideradas negativas as células que não exibiam esta coloração. 
Resultados 


\section{RESULTADOS}

Foi preciso transplantar 4 germes de primeiros molares superiores sob a cápsula renal de cada um dos rins de cada animal com a finalidade de se escolher ao menos 2 para análise histológica e imunoistoquímica. Em contrapartida, cada osso da tíbia pode receber o implante de apenas um germe dental.

Do total de germes transplantados para os rins, aproximadamente $50 \%$ era perdido, ou por ter rompido a cápsula renal e extravasado para o peritônio após o rim ter sido recolocado na cavidade abdominal ou por estarem rodeados por áreas hemorrágicas coaguladas, talvez formadas em decorrência do trauma que o dente exercia no local.

Na tíbia, é preciso considerar que a proposta do estudo era avaliar 9 animais no grupo T1 e 9 animais no grupo T2, e que precisaríamos então de êxito no transplante e ambas tíbias nos 18 experimentos. Para conseguirmos este número de amostra, foram necessárias 33 cirurgias, ou seja, $45 \%$ a mais do que o planejado. 0 motivo para tal foi que em 15 animais, ao menos uma das patas apresentou supuração e/ou fratura na área operada.

No que concerne a avaliação da posição em que o germe dental foi transplantado em cada uma das tíbias, pode-se observar que os germes transplantados com os forames voltados para o periósteo tiveram um desenvolvimento prejudicado quando comparado com os implantados com o forame voltado para o interior do espaço medular. Apesar da significativa diferença entre as suas morfologias, não houve diferença alguma no padrão de expressão imunoistoquimica, em nenhum dos casos analisados, para nenhum dos imunomarcadores analisados, conforme será apresentado a seguir. 


\subsection{Animais que receberam os germes dentais dos doadores com 2 dias de vida pós-natal e com proservação de 3 dias}

Do ponto de vista morfológico, os primeiros molares superiores dos animais com 5 dias vida pós-natal (animais D5) - que equivalem cronologicamente aos germes dentais de animais D2 transplantados por 3 dias - apresentam-se em fase inicial de mineralização da matriz dentinária na região de cúspides, camada de ameloblastos uniforme, bainha radicular de Hertwig organizada e composta por duas camadas celulares, tecido pulpar moderadamente celularizado e ricamente vascularizado, onde inclusive já é possível se notar a presença de grandes vasos sanguíneos do plexo principal adentrando a polpa dental, bem como de suas ramificações até a região subodontoblástica. $\mathrm{O}$ folículo dental mostrou-se composto por tecido conjuntivo frouxo, porém organizado e bem delimitado (Figura 5.1C).

Os primeiros molares superiores de animais D2 transplantados por 3 dias sob as cápsulas renais mostraram alterações significativas na sua morfologia (Fig ura 5.1A). Apesar da visível deposição de dentina primária e secundária e de esmalte em alguns pontos isolados, é evidente desorganização e/ou degeneração da camada de odontoblastos e atrofia e degeneração da camada de ameloblastos (Fig ura 5.1 $\mathrm{A}^{`}$ ), assim como do folículo dental. Além disso, na predominante massa dos espécimes analisados foi encontrada a formação de osteodentina pelas células da polpa dental, principalmente na região da bainha radicular de Hertwig. A polpa dental encontrava-se comumente hipercelularizada, com áreas de edema e hemorragia, bem como com vasos sanguíneos hiperdilatados e congestos.

Na região de implantação dos primeiros molares superiores de animais D2 nas tíbias, após 3 dias da cirurgia era evidente um intenso infiltrado inflamatório agudo, células hematopoiéticas, extensas áreas hemorrágicas e neoformação óssea (Figura 5.1B). Os dentes transplantados para este sítio, por este período de tempo de avaliação, apresentavam uma moderada conservação da sua morfologia, com deposição de dentina primária e secundária e desorganização e/ou degeneração quase que total tanto da camada de ameloblastos quanto do folículo dental (Figura 5.1B`). A polpa dental encontrava-se, na maioria dos casos, com celularidade 
similar a polpa de um dente sadio, mas com a camada de odontoblastos desorganizada, áreas hemorrágicas e edema. Este último localizava-se predominantemente na região de cornos pulpares.

Quando os dentes dos animais D5 foram analisados por imunoistoquímica, pode-se observar que o marcador para CD105 evidenciou, de maneira clara, a neoformação de vasos sanguíneos na polpa dental (principalmente próximo aos odontoblastos), no folículo dental e nos tecidos de suporte (Figura 5.1F). Ademais, foi encontrado marcação positiva uniforme de CD105 no tecido conjuntivo localizado externamente ao dente, na região de periápice. O marcador imunológico anti-VEGF apresentou um padrão de expressão muito similar ao CD105 não só nos dentes dos animais D5 (Figura 5.1I), mas em todos os experimentos desta pesquisa. Desta forma, vale ressaltar apenas, neste caso, que o VEGF parece ser mais específico pra vasos sanguíneos mais maduros, além de mostrar-se de maneira mais intensa que o CD105, na região de periápice. Nos germes dentais de animais D2 transplantados sob a cápsula renal por 3 dias, pode-se observar uma expressão de CD105 em poucos locais (Figura 5.1D), deixando claro então a pouca neoformação vascular nestes tecidos (Figura 5.1D '). O mesmo pode-se dizer para o VEGF (Figuras 5.1G e 5.1G') sendo este, assim como o CD105 também expresso na região de papila apical. Esses mesmos marcadores, quando utilizados nos germes dos animais D2 transplantados por 3 dias na tíbia, não puderam ser evidenciados em praticamente nenhum vaso sanguíneo mas, em contrapartida, foram expressos de maneira uniforme por quase que a totalidade das células dos dois terços coronais do tecido pulpar (CD105 (Figura 5.1E) e VEGF (Figura 5.1H)). A porção apical da polpa dental apresentou-se negativa.

A imunomarcação para o anticorpo anti-AML pode ser evidenciada nas células mioepiteliais que, por sua vez, se mostraram presentes circundando externamente todo o germe dental dos animais D5 e abluminalmente as células endoteliais dos vasos sanguíneos (Figura 5.1L). Nos germes dentais de animais D2 transplantados sob a cápsula renal por 3 dias observou-se a presença de células mioepiteliais na maioria dos vasos sanguíneos (principalmente nos mais calibrosos (Figura 5.1J') e em algumas regiões do folículo dental e porção apical da polpa dental (Figura 5.1J). Nos germes dentais de animais D2 transplantados para a tíbia, 
a AML foi presente, com uma frequência menos que os dentes implantados nos rins, apenas na parede de alguns vasos sanguíneos (Figuras $5.1 \mathrm{~K}$ e $5.1 \mathrm{~K}^{`}$ ).

O anticorpo anti-PDGFR- $\beta$ evidenciou os pericitos/células perivasculares nos vasos sanguíneos da polpa dos germes dentais dos primeiros molares superiores dos animais D5, bem como os pericitos dos vasos sanguíneos do folículo dental e adjacências (Figura 5.10). Além disso, o PDGFR- $\beta$ pode ser evidenciado na camada de odontoblastos e no epitélio interno do órgão do esmalte. Nos germes dentais de animais D2 transplantados sob a cápsula renal por 3 dias o anticorpo anti-PDGFR- $\beta$ foi nos odontoblastos que, aparentemente, estão fase inicial de secreção de matriz dentinária; na porção apical da polpa dental e; fracamente, em células esparsas na porção central do tecido pulpar (Figura 5.1M). Esse mesmo antígeno, nos germes dentais transplantados nas tíbias, foi evidenciado, fracamente, no citoplasma dos odontoblastos e na porção apical da polpa dental (Figura $5.1 \mathrm{~N}$ ).

O antígeno NG2 foi comumente encontrado nos germes dentais dos animais D5 nas seguintes localidades: nos pericitos/células perivasculares dos vasos sanguíneos presentes nos tecidos dentais e peridentais, nos odontoblastos secretantes de matriz dentinária, na bainha radicular de Hertwig, nas células do folículo dental e no tecido conjuntivo periapical (Figura 5.1R). Esse mesmo padrão de imunomarcação pode ser evidenciado nos germes dentais transplantados tanto sob a cápsula renal (Figura 5.1P) quanto na tíbia (Figura 5.1Q) valendo ressaltar então que praticamente não há odontoblastos NG2 positivos na polpa dos dentes para a tíbia assim como a sua expressão nos pericitos é bem menos evidente.

A proteína nestin foi fortemente expressa nos odontoblastos secretantes de matriz dentinária nos germes dentais dos animais D5 e moderadamente expressa no feixe nervoso localizado próximo ao ápice do dente e no tecido conjuntivo do periápice dental (Figura 5.1U). Diferentemente do NG2, a nestin não é expressa na bainha radicular de Hertwig. Nos germes dentais de animais D2 transplantados sob a cápsula renal por 3 dias a nestin apresentou o mesmo padrão de expressão dos dentes controles, acrescido que, nestes casos, também era fortemente expressa nas células secretoras de dentina terciária do tipo reparativa (osteodentina) (Figura 
5.1S). Já nos germes dentais transplantados na tíbia, não foi observada expressão de nestin, salvo, esporadicamente, em odontoblastos isolados (Figura 5.1T).

A expressão da proteína S100 ficou restrita ao feixe nervoso localizado lateralmente a porção apical dos germes dentais dos animais D5 (Figura 5.1Z) e nas células mioepiteliais que circundam externamente os germes transplantados para os rins (Figura 5.1V). Não foi observada expressão de S100 em nenhum corte histológico dos dentes transplantados na tíbia (Figura 5. 1X). 
Figura 5.1 - Grupo controle e grupos de germes de animais D2 transplantados para os rins e tíbias, com 3 dias de proservação.

Coloração em HE; aumento de 2,5x (5.1B), de 10x (5.1A, 5.1B' e 5.1C) e de 40x (5.1A'); Expressão de CD105 evidenciando a presença incipiente de vasos sanguíneos na polpa dental do grupo controle, aumento de 10x (5.1F); esporádica/fraca expressão nos vasos sanguíneos da polpa dos dentes implantados nos rins, , aumento de 10x (5.1D) e 40x (5.1D '), e generalizada nas células da polpa dental dos dentes implantados nas tíbias, , aumento de 10x (5.1E). Expressão de VEGF, seguindo padrão similar ao de CD105, aumento de $10 x$ (5.1G, $5.1 \mathrm{H}$ e $5.1 \mathrm{I})$ e de $40 \times\left(5.1 \mathrm{G}^{\prime}\right)$. Expressão de AML nas células do folículo dental, aumento de 10x (5.1L); e, nas células perivasculares, aumento de $10 \times$ (5.1J) e de $40 \times$ (5.1J '), menos comumente vistas na polpa dos dentes implantados nas tíbias, aumento de 10x (5.1k) e de 40x (5.1K'). Expressão de PDGFR- $\beta$ no tecido periapical e nos odontoblastos em fase inicial de secreção da matriz dentinária, aumento de 10x (5.10), mais restritos a regiões focais nos dentes implantados nos rins, aumento de $10 \mathrm{x}(5.1 \mathrm{M})$ e de $40 \mathrm{x}\left(5.1 \mathrm{M}^{\prime}\right)$, e praticamente inexistente na polpa dos dentes implantados nas tíbias, aumento de 10x (5.1N). Expressão positiva de NG2 nos pericitos e nos odontoblastos em fase inicial de secreção de matriz dentinária, aumento de $10 x(5.1 \mathrm{R}$ e $5.1 \mathrm{P})$ e ausência de positividade na grande maioria das células da polpa dos dentes implantados nas tíbias, aumento de $10 x$ (5.1Q). Expressão de nestin, evidencianda em aumento de 10x no tecido nervoso peridental e odontoblastos ativos (5.1U); positividade para nestin tanto pelos odontoblastos produtores de dentina secundária quanto de terciária, aumento de 10x (5.1S), e ausência de marcação na polpa dos dentes implantados nas tíbias, aumento de 10x (5.1T). A proteína S100 foi fortemente expressa no feixe nervoso peridental, mas ausente no tecido pulpar tanto no grupo controle, , aumento de 10x (5.1Z), quanto nos experimentais, aumento de $10 x$ (5.1V e 5.1X). 
RIM
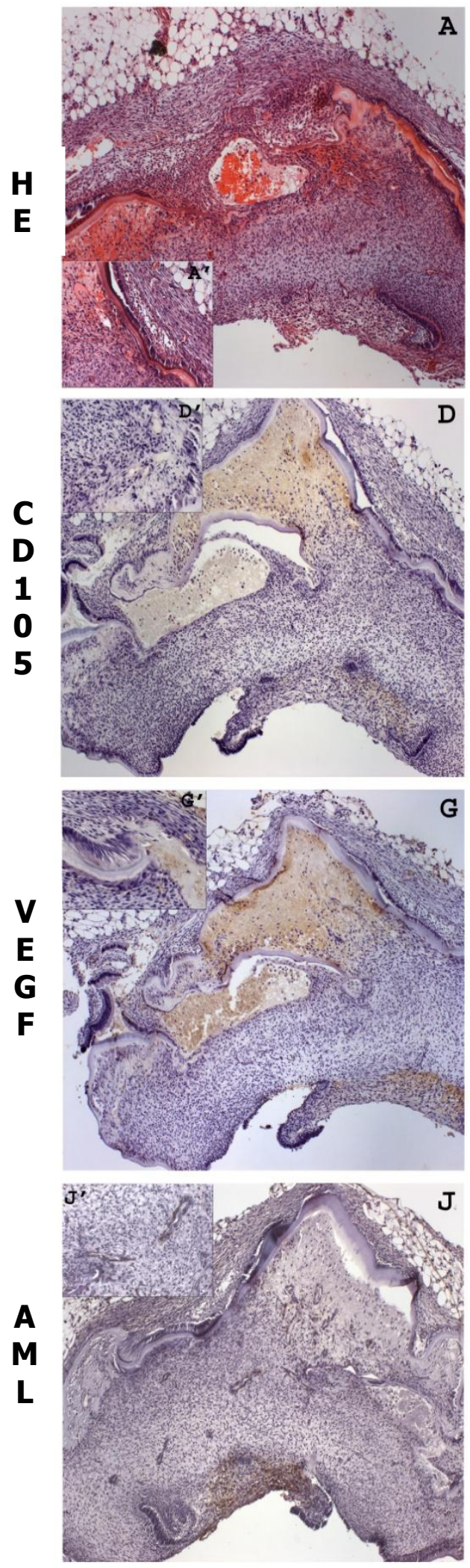

TÍBIA
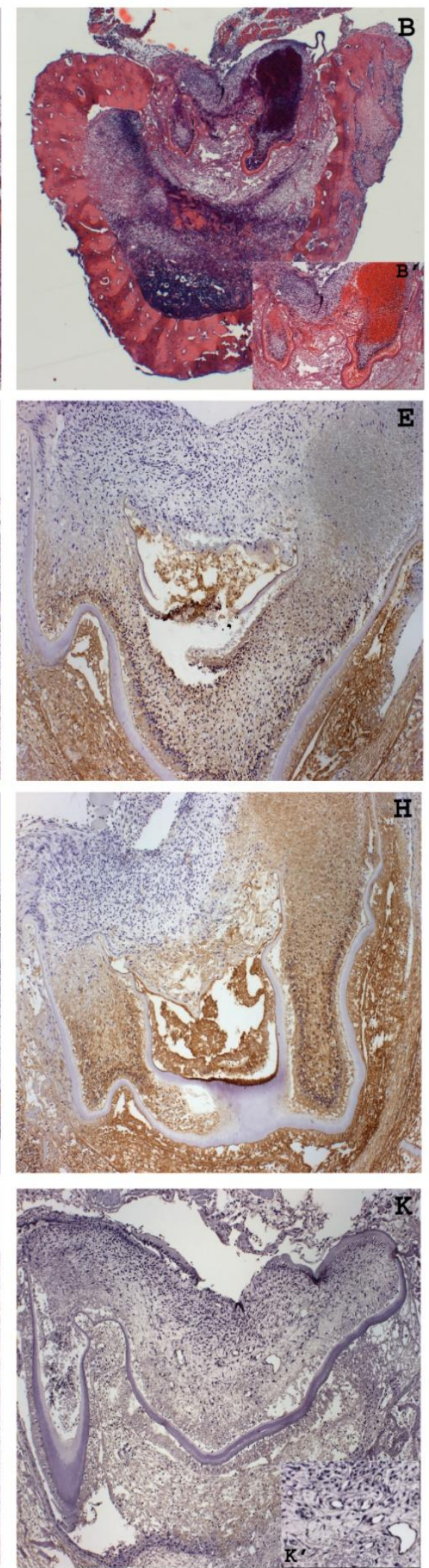

CONTROLE
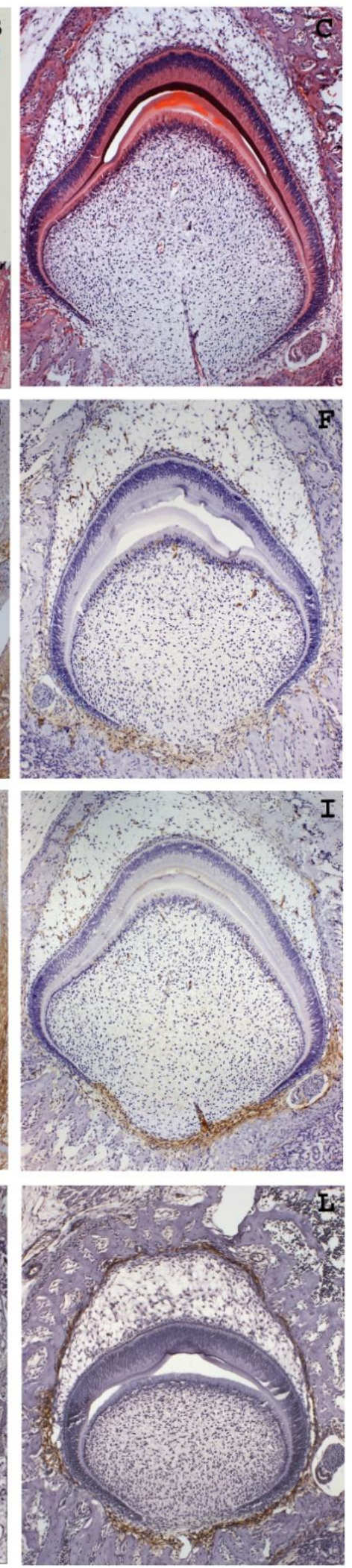
RIM
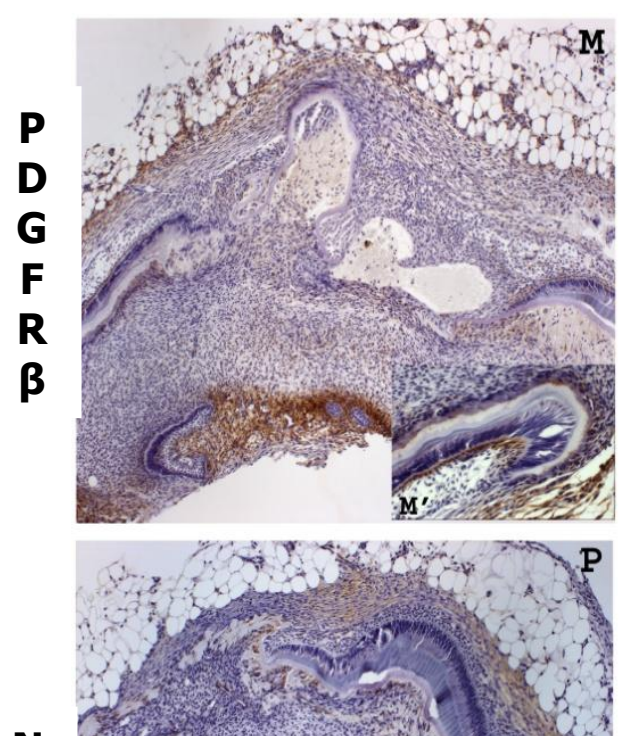

$\mathbf{N}$

G

2
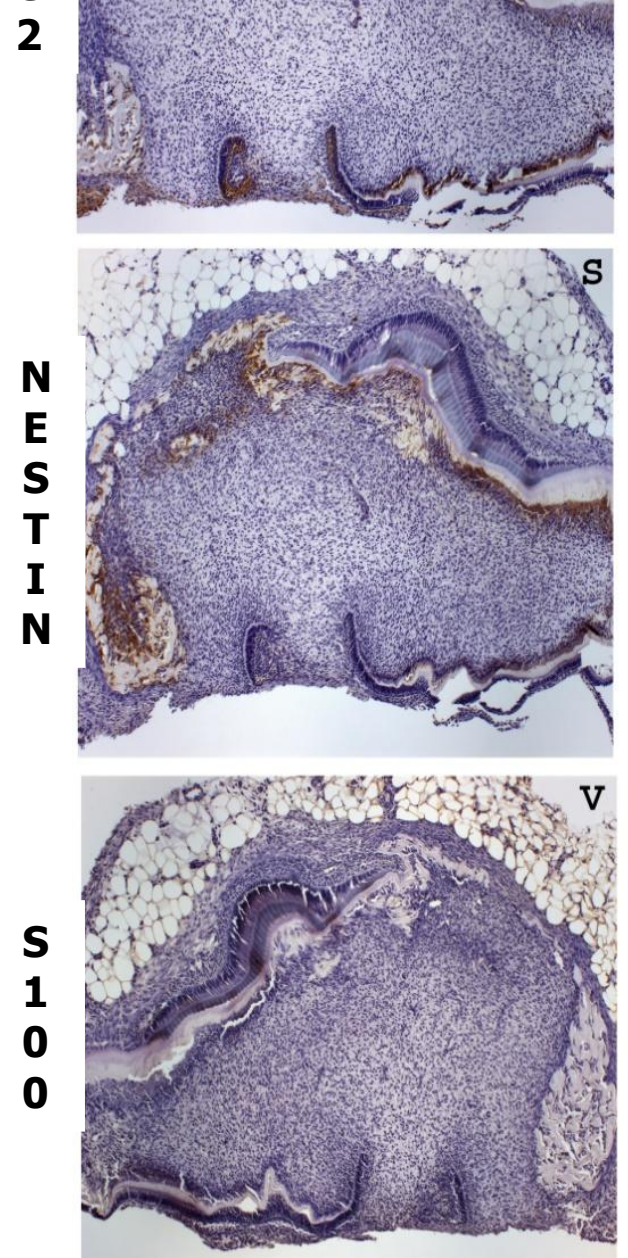

TÍBIA
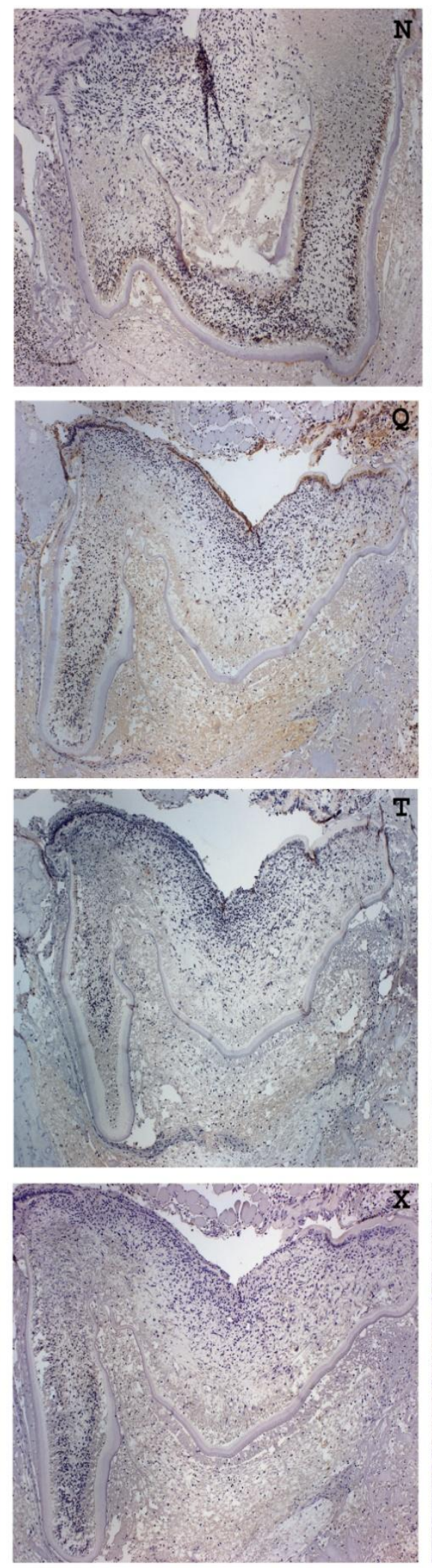

CONTROLE
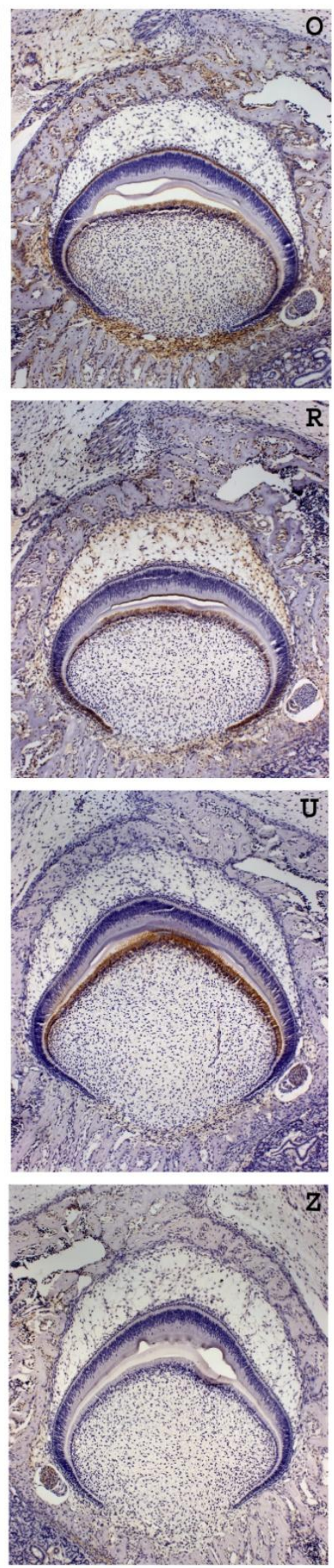


\subsection{Animais que receberam os germes dentais dos doadores com 2 dias de vida pós-natal e com proservação de 7 dias}

O grupo controle para os experimentos desse grupo foi composto por animais com 9 dias de vida pós-natal (animais D9), equivalendo em tempo, portanto, o período de desenvolvimento dos germes dos animais D2 somado ao tempo de proservação (7 dias).

A análise morfológica dos germes dentais in loco dos animais D9 revelou dentes com uma coroa bem formada, camada de dentina e esmalte bem definidas, bainha radicular de Hertwig composta por duas camadas celulares bem organizadas, folículo dental mais atrófico que o dos animais D5 e polpa dental composta por um tecido conjuntivo frouxo, moderadamente celularizado, com uma camada de odontoblastos organizada e com uma rica vascularização em seu interior (Figura 5.2C). É digno de nota também que a camada de ameloblastos encontra-se íntegra e bem organizada em torno de toda a coroa dental, mas já mostra sinais de atrofia nas áreas com menor necessidade de deposição de esmalte, como a pontas de cúspide, por exemplo.

Quando os germes dentais de animais D2 foram transplantados sob a cápsula renal durante 7 dias, tiveram alterações morfológicas ainda mais significativas que os transplantados por apenas 3 dias. Dentre elas, pode-se salientar a intensa formação de osteodentina, a desorganização da camada de ameloblastos e odontoblastos, a deposição de esmalte e dentina sadios em apenas alguns pontos da coroa dental e a presença de uma bainha radicular de Hertwig, na maioria das vezes, desorganizada e produzindo dentina reparativa. A polpa dental comumente apresentava áreas de edema e hemorragia, hipercelularidade e hipovascularização e, curiosamente, pode ser observado uma tentativa da polpa dental se isolar do meio exterior formando uma barreira de osteodentina na porção apical do tecido pulpar (Figura 5.2A).

Comparativamente, quando os germes, em mesmas condições de desenvolvimento, eram transplantados para as tíbias e mantidos neste sítio pelo mesmo período de tempo que nos rins, alteração significativa da morfologia dental 
podia ser notada (Figura 5.2B). Raros são os pontos com deposição de esmalte e não obstante pode-se observar células clásticas fazendo reabsorção tanto do esmalte quanto da dentina que estejam em contato com o tecido ósseo. A polpa dental encontrou-se predominantemente hipocelularizada; com aspecto mixóide, principalmente nas regiões de ponta de cúspide; com predominância de vasos sanguíneos hiperdilatados e congestos e com a camada de odontoblastos desorganizada ou ausente (Figura 5.2B').

A análise imunoistoquimica dos germes dentais do grupo controle (animais D9) para a expressão da proteína CD105 mostrou que, agora, ela está expressa não exclusivamente nas células endoteliais dos vasos sanguíneos em desenvolvimento, mas também, fraca e uniformemente, nos fibroblastos do tecido conjuntivo que compõe a polpa dental e o plexo periapical (Figura 5.2F). Contrariamente, a polpa dental dos dentes implantados nos rins não apresenta imunomarcação para a CD105 na grande maioria dos casos (Figura 5.2D), estando ausente até mesmo nos vasos mais jovens (Figura 5.2D`). No caso dos dentes implantados na tíbia, podese observar marcação exuberante tanto no endotélio dos vasos sanguíneos em desenvolvimento (Figura 5.2E') quanto no tecido conjuntivo pulpar e no tecido de granulação que envolve os germes transplantados (Figura 5.2E).

A marcação imunoistoquimica para o anticorpo anti-VEGF tanto no grupo controle (Figura 5.2I) quanto nos dentes transplantados para os rins (Figuras 5.2G e $5.2 \mathrm{G}^{\prime}$ ) ou nas tíbias (Figuras $5.2 \mathrm{H}$ e $5.2 \mathrm{H}^{\prime}$ ) seguiu o mesmo padrão de marcação do anticorpo anti-CD105.

Ao investigar-se a presença das células de musculatura lisa perivasculares através do uso do anticorpo anti-AML, notou-se que, tanto no grupo controle (Figura 5.2L) quanto nos dentes implantados nos rins (Figuras 5.2J e 5.2J'), a marcação foi restrita à porção abluminal dos vasos sanguíneos e às células mioepiteliais localizadas no folículo dental e periápice. Em contrapartida, nos dentes implantados nas tíbias, além da AML ser evidenciada em torno dos vasos sanguíneos e nas células mioepiteliais localizadas no folículo dental e no periápice, podia ser encontrada de maneira homogênea no tecido conjuntivo da polpa dental, principalmente nas porções dos cornos pulpares, onde o tecido pulpar encontravase frouxo e edemaciado. 
Os animais D9 os primeiros molares superiores começam a expressar PDGFR- $\beta$ em todas as células da polpa dental e, de maneira ainda mais expressiva, na camada de células odontoblasticas, subodontoblasticas e pericitos (Figura 5.20). O PDGFR- $\beta$ também foi evidenciado nos pericitos dos vasos sanguíneos dos tecidos peridentais, no tecido conjuntivo da região periapical e nos osteoblastos que revestem as trabéculas ósseas da cripta óssea dental. Nos dentes implantados nos rins, o PDGFR- $\beta$ é raramente encontrado nas células perivasculares (Figura 5.2M '). Além disso, nesse grupo analisado, o anticorpo anti-PDGFR- $\beta$ marcou apenas os odontoblastos que estão, aparentemente, em atividade, seja secretando dentina secundária ou terciária, em regiões esparsas do folículo dental e tecido conjuntivo próximo a região periapical (Figura 5.2M). Nos dentes implantados na tíbia, o PDGFR- $\beta$ marcou células perivasculares (embora em menos frequência que no grupo controle) e, similarmente ao grupo controle, marcou, moderadamente, todas as demais células da polpa dental, do tecido conjuntivo periapical e de regiões pontuais do folículo dental (Figuras 5.2N e 5.2N`).

O anticorpo anti-NG2 marcou fortemente os pericitos dos vasos sanguíneos dentais e peridentais no grupo controle, sendo também evidenciado no folículo dental, tecido conjuntivo periapical e, fracamente, pelas demais células da polpa dental. Além disso, vale salientar que sua expressão é negativa nos odontoblastos quiescentes (localizados principalmente nos cornos pulpares) e positiva nos odontoblastos com aparente atividade secretora (Figura 5.2R). Nos dentes implantados nos rins, a proteína NG2 é encontrada nos raros pericitos presentes no tecido pulpar, nos odontoblastos ativos e em regiões pontuais do folículo dental e periápice (Figuras 5.2P e 5.2P'). Já nos dentes implantados nas tíbias, a NG2 além de ser encontrado nos raros pericitos do tecido pulpar e peridental (Figura 5.2Q ') é expresso por quase que a totalidade das células da polpa dental e tecido conjuntivo periapical bem como em regiões pontuais do folículo dental, similarmente ao grupo controle (Figura 5.2Q).

Como de esperado, a nestin foi fortemente expresso pelos odontoblastos da polpa dental dos germes dos animais D9, bem como pelo feixe nervoso localizado lateralmente e externamente ao periápice dental. Ademais, células do tecido pulpar nos cornos pulpares e nas regiões próximas a bainha radicular de 
Hertwig expressam, embora que fracamente, nestin (Figura 5.2U). Nos dentes implantados nos rins a nestin tem um padrão de marcação muito similar ao da proteína NG2, excetuando-se pelo fato de não ser um marcador de pericitos e também mostrar-se positivo nas células produtoras de dentina reparataiva (Figuras $5.2 \mathrm{~S}$ e $5.2 \mathrm{~S}^{\prime}$ ). Igualmente à $\mathrm{NG} 2$, a nestin marcou, nos dentes implantados na tíbia, quase que a totalidade de células da polpa dental e do tecido conjuntivo periapical bem como regiões pontuais do folículo dental (Figura 5.2T). Diferentemente do padrão de marcação da nestin nos dentes do grupo controle e dos implantados no rim, nos dentes implantados na tíbia não pode ser evidenciada a presença de nestin nos odontoblastos da polpa dental, uma vez que essas células parecem fora de atividade, desorganizadas e/ou apoptóticas.

A proteína S100 pode ser evidenciada fortemente no feixe nervoso localizado lateralmente ao periápice dental nos germes do grupo controle bem como, fracamente, por células do tecido conjuntivo periapical (Figura 5.2Z). Nos germes dentais implantados nos rins a proteína S100 foi encontrada apenas nas células mioepiteliais do folículo dental (Figura 5.2V) e nos germes dentais implantados na tíbia foi encontrada de maneira homogênea no tecido pulpar, principalmente na região dos cornos pulpares e no tecido conjuntivo periapical (Figura 5.2X). 
Figura 5.2 - Grupo controle e grupo de germes de animais D2 transplantados para os rins e tíbias, com 7 dias de proservação.

Coloração em HE, aumento de 2,5x (5.2B') e de $10 x$ (5.2A, 5.2B e 5.2C). Esporádica expressão de CD105, mesmo nos vasos mais jovens na polpa dos dentes implantados nos rins, aumento de $10 x$ (5.2D) e de 40x (5.2D '); moderada expressão de CD105 pelas células da polpa dental no grupo controle, aumento de $10 \mathrm{x}$ (5.2F); e, forte expressão de CD105 pelas células da polpa dental e pelo tecido de granulação nos dentes implantados nas tíbias, aumento de 10x (5.2E) e de 40x (5.2E'). Expressão de VEGF, muito similar a de CD105, tanto no grupo controle, aumento de $10 \mathrm{x}$ (5.2I), quanto nos grupos experimentais, aumento de $10 x(5.2 \mathrm{H}$ e $5.2 \mathrm{G})$ e de $40 \mathrm{x}\left(5.2 \mathrm{G}^{\prime}\right.$ e $\left.5.2 \mathrm{H}^{\prime}\right)$. Expressão de $\mathrm{S} 100$ no feixe nervoso peridental e tecido conjuntivo periapical, aumento de 10x (5.2L); expressão de $A M L$, fraca, mas generalizada, na polpa de alguns espécimes implantados nas tíbias, aumento de 10x (5.2k) e de 40x, evidenciando maior expressão de AML nas células perivasculares $\left(5.2 \mathrm{~K}^{\prime} \mathrm{e}\right.$ 5.2J '); há ausência de expressão de AML pelas células da polpa dos dentes implantados nos rins, aumento de 10x (5.2J). Forte expressão de PDGFR- $\beta$ na camada odontoblástica e subodontoblástica bem como pelo tecido pulpar e periapical, aumento de 10x (5.20); expressão de PDGFR- $\beta$ moderada e difusa pelas células da polpa dental, mas ausente na periferia do tecido pulpar, aumento de $10 x(5.2 \mathrm{~N})$, e na grande maioria das células perivasculares, aumento de $40 \times$ ( $\left.5.2 N^{\prime}\right)$; expressão de PDGFR- $\beta$ em áreas focais do tecido pulpar, aumento de 10x (5.2M), ausência de marcação na maioria das células perivasculares, aumento de $40 x\left(5.2 M^{\prime}\right)$. Moderada expressão de NG2 no tecido pulpar e células perivasculares, aumento de $10 \times(5.2 \mathrm{R}, 5.2 \mathrm{Q})$, bem com nos odontoblastos ativos, aumento de $10 x(5.2 \mathrm{M})$ e $40 x$ (5.2Q e $\left.5.2 \mathrm{P}^{\prime}\right)$. Expressão de nestin evidenciando odontoblastos ativos, aumento de $10 \times(5.2 \mathrm{U}$ e $5.2 \mathrm{~S}$ ) e de $40 \mathrm{x}\left(5.2 \mathrm{~S}^{\prime}\right)$ e ausência dos mesmos, aumento de 10x (5.2T). Expressão de S100 positiva no tecido periapical e feixe nervoso peridental, aumento de 10x (5.2Z), difusa ao longo do tecido pulpar, aumento de 10x (5.2X) ou restrita a células mioepiteliais peridentais, aumento de 10x (5.2V). 

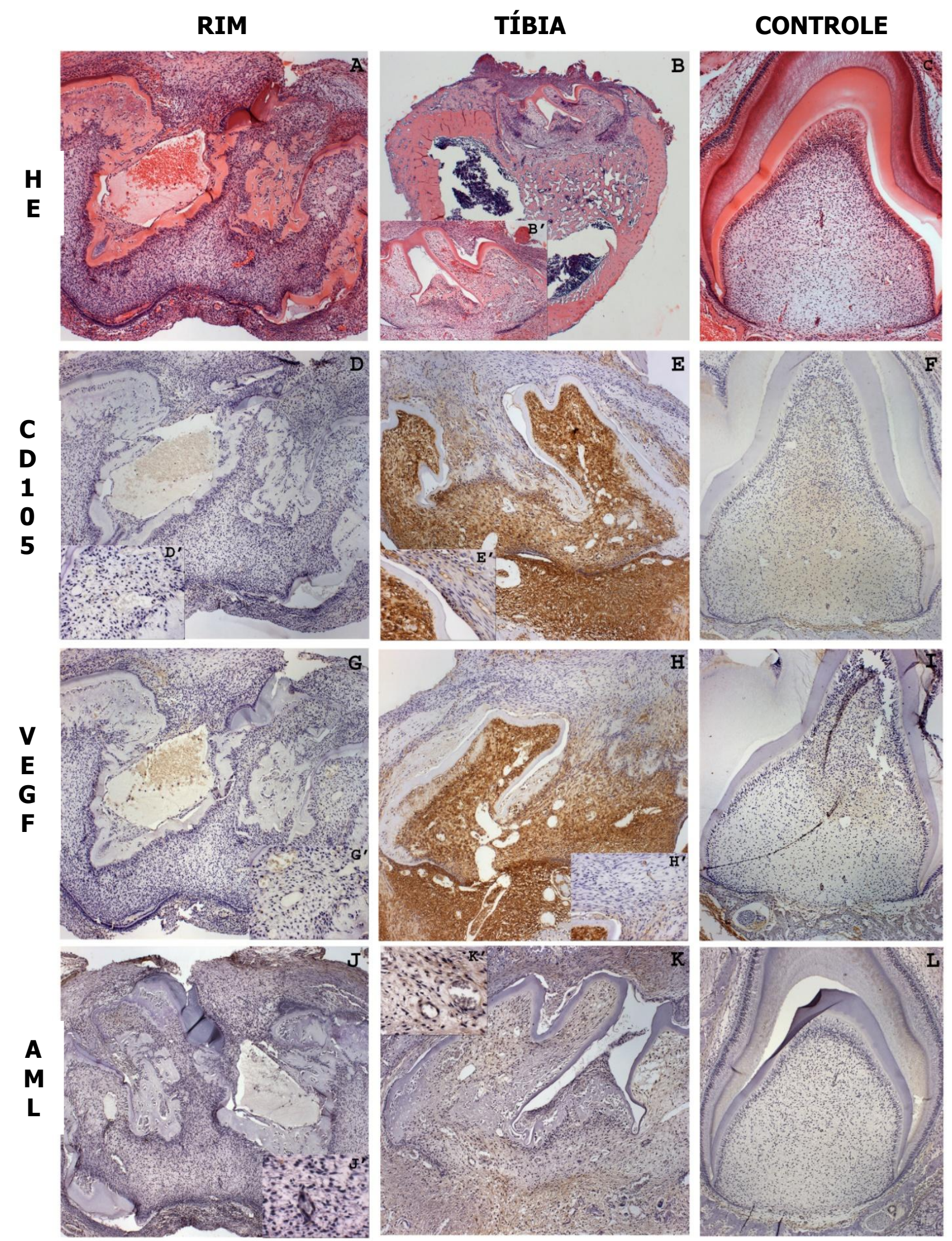


\section{RIM}
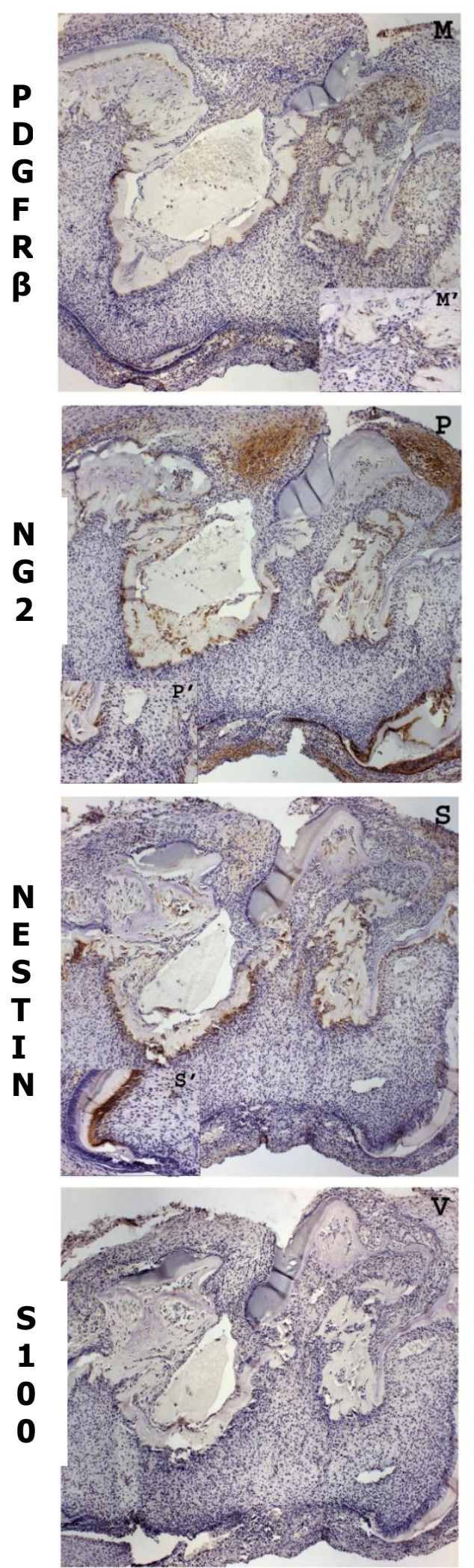

TÍBIA
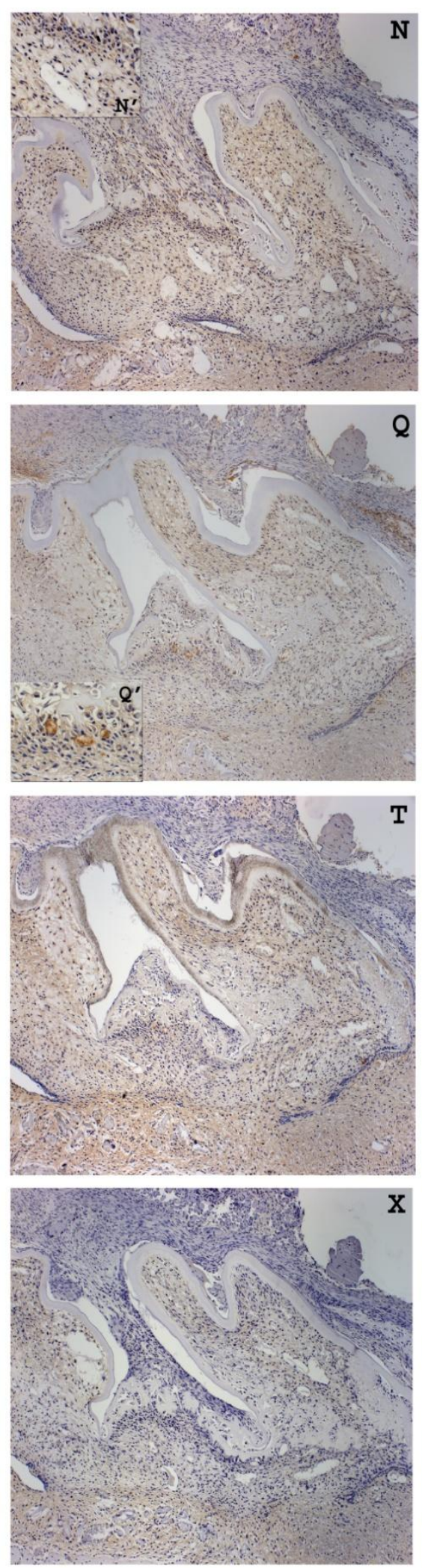

CONTROLE
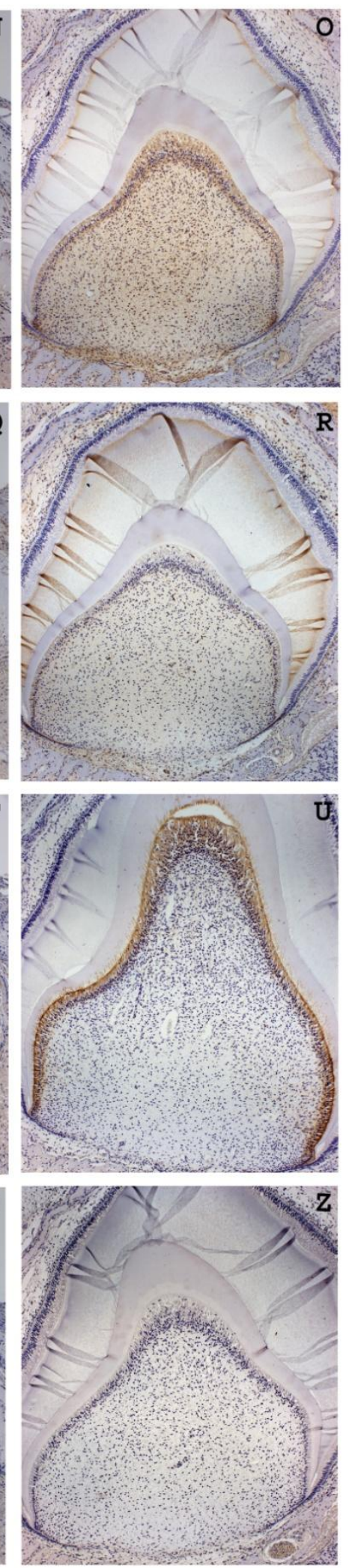


\subsection{Animais que receberam os germes dentais dos doadores com 2 dias de vida pós-natal e com proservação de 11 dias}

Como controle do grupo dos animais que receberam os germes dentais de animais D2 e que foram proservados por 11 dias, foram analisados os primeiros molares superiores de animais 13. Nesta fase do desenvolvimento (décimo terceiro dia de vida pós-natal), os dentes mostraram possuir a coroa dental completamente formada e a raiz em vias de fato. De maneira geral, notou-se deposição de dentina primária e secundária; camada de esmalte espessa; camada ameloblastos organizada, porém atrófica; camada de odontoblastos em paliçada; raiz com dois terços de formação; diafragma epitelial bem formado e polpa dental composta por um tecido conjuntivo frouxo ricamente permeado por vasos sanguíneos calibrosos e congestos (Figura 5.3C). Quando realizada análise morfológica dos dentes transplantados para os rins seguindo os mesmo critérios para o grupo controle, percebe-se que os dentes sofrem uma alteração em sua morfologia ainda mais acentuada do que quando mantidos neste sítio anatômico por apenas 7 ou 3 dias. Neles, há indícios de deposição de dentina primária organizada em poucas áreas, sendo então predominante a formação de dentina reparativa (Figura 5.3A). O esmalte dental encontra-se irregular, não recobrindo toda a coroa dental na maioria dos casos e com ausência de ameloblastos nas sua superfície. A polpa dental encontrou-se ricamente celularizada, com vasos sanguíneos hiperdiatados. Edema e hemorragia também foram achados comuns na polpa desses dentes. Além disso, a camada de osteodentina formada na porção apical da polpa dental nos dentes mantidos no rim por 11 dias é ainda maior que quando mantido por apenas 7 ou 3 dias, dando a impressão de que quanto maior o tempo, mais evidente é a tentativa da polpa dental em se proteger, isolando-se do meio externo por uma barreira de tecido mineralizado. Por fim, o folículo dental encontrou-se atrófico na maioria dos casos e parece ficar tão mais atrófico quanto maior for o tempo de permanência do dente sob a cápsula renal.

Comparativamente, quando os dentes, em mesmas condições de desenvolvimento, são transplantados para as tíbias e proservados pelo mesmo 
período de tempo, pode-se observar a formação de osteodentina na totalidade dos casos analisados, porém, de forma mais localizada (geralmente próxima a bainha radicular de Hertwig ou onde o tecido pulpar estava em contato direto com o tecido ósseo adjacente) que os dentes formados no rim. No entanto, vale deixar claro que, de maneira geral, a morfologia dos dentes desenvolvidos na tíbia é mais afetada do que os desenvolvidos rins. A questão é que parece que os dentes, ao serem colocados no na tíbia, são vistos pelo organismo como um "corpo estranho" e, na maioria das vezes, envolvem. O caso apresentado na figura 5.3B - visto em maior detalhe na figura $5.3 \mathrm{~B}^{`}$ - foi um dos poucos casos onde pode-se observar um dente relativamente bem desenvolvido na tíbia, havendo inclusive grande produção de osteodentina em algumas regiões (Figura 5.3B' '). Esse não foi o padrão de desenvolvimento da maioria das amostras nesse período de acompanhamento.

Através do uso das reações de imunoistoquímica utilizando os imunomarcadores de desenvolvimento vascular CD105 e VEGF, notamos que tanto os dentes implantados no rim (Figuras 5.3D e 5.3G) quanto os implantados na tíbia (Figuras 5.3E e 5.3H) raramente possuem uma neovascularização. Os neovasos, quando presentes, são vistos, geralmente, apenas externamente aos dentes (como no folículo dental, por exemplo) (Figura 5.3D '). Além disso, os vasos sanguíneos presentes na polpa dental apresentam-se hiperdilatados (Figura 5.3H') e não estão distribuídos de maneira uniforme ou condizente com o padrão tido como normal visto nos grupos controles (Figuras 5.3F e 5.3I).

Intrigantemente, a medida que os dentes prosseguem 0 seu desenvolvimento in loco (o que pode ser visto nos grupos controles) eles aumentam a expressão constitutiva de CD105 e de VEGF (Figuras 5.3F e 5.3I, respectivamente) e, somente os dentes implantados nas tíbias é que se assemelham com esse padrão de expressão. Dessa forma, embora menos evidente, o tecido conjuntivo da polpa dental e adjacências nos dentes implantados na tíbia também expressam de uma maneira generalizada CD105 e VEGF a medida que permanecem por um maior período de tempo neste sítio de desenvolvimento (Figuras 5.3E e 5.3H). O mesmo não acontece com os dentes implantados sob as cápsulas renais (Figuras 5.3D e 5.3G). 
Quando avaliada a presença de células perivasculares (musculatura lisa e pericitos) utilizando-se os marcadores anti-AML, anti-PDGFR- $\beta$ e anti-NG2, tanto os dentes implantados nos rins quanto os implantados na tíbia, os "sub-expressam", comparativamente ao grupo controle.

A AML, além de estar presente nas células mioepiteliais envolvendo a maioria dos vasos sanguíneos da polpa dental nos animais do grupo controle, também pode ser evidenciada no tecido conjuntivo do periápice e periodonto (Figura 5.3L). Nos dentes implantados no rim a AML foi evidenciada, pontualmente, no folículo dental (Figura 5.3J), mas não estava presente na maioria dos vasos sanguíneos (Figura 5.3J'). O mesmo pode-se dizer a respeito dos dentes implantados nas tíbias (Figura 5.3K).

A PDGFR- $\beta$ e a NG2 também apresentaram um padrão curioso de expressão no grupo controle: tanto a PDGFR- $\beta$ (Figura 5.30) quanto a NG2 (Figura 5.3R) deixam de ser expressos estritamente pelos pericitos, a medida que os germes dentais completam o seu desenvolvimento, e passam a ser evidenciadas em praticamente todas as células da polpa dental e do tecido conjuntivo periapical e periodontal. Vale ainda ressaltar que a NG2 tem como padrão uma super expressão na camada de células subodontoblásticas e sempre está presente na camada de odontoblastos com aparente atividade secretante. Vale salientar que a expressão de NG2 é negativa nos odontoblastos quiescentes (localizados nos cornos pulpares).

Quando avaliado a presença destas mesmas proteínas nos dentes implantados nos rins e nas tíbias, observa-se que há uma expressão de moderada a fraca de PDGFR- $\beta$ pelo tecido pulpar dos dentes implantados nas tíbias (Figura 5.3N) e ausente nos dentes implantados nos rins (Figura 5.3M). Em relação ao NG2, parece estar presente apenas nos odontoblastos em atividade. Desta forma, pode ser visto nos dentes implantados na tíbia apenas na camada de odontoblastos próxima a bainha radicular de Hertwig (Figura 5.3Q) e, ao mesmo tempo, os dentes implantados nos rins, ao longo de quase toda a camada de odontoblastos da polpa (Figura 5.3P).

A medida que o dente segue o seu desenvolvimento a nestin tem uma expressão diminuída pelos odontoblastos no grupo controle (Figura 5.3U), ficando 
mais evidente nas células de origem nervosa tais quais a do feixe nervoso localizado lateralmente ao periápice e no tecido conjuntivo periapical e periodontal.

Nos dentes implantados nos rins, observamos uma expressão uniforme de nestin por quase que a totalidade dos odontoblastos da periferia da polpa dental, sejam elas as produtoras de dentina secundária ou reparativa (Figura 5.3S). Ademais, pode-se observar a presença de nestin em regiões pontuais do folículo dental. A expressão de nestin nos dentes implantados nas tíbias é menor que nos implantados nos rins, estando restrita a uma minoria de odontoblastos e em regiões pontuais do tecido conjuntivo que circunda o dente (Figura 5.3T).

$E$, por fim, a expressão de $S 100$ também é evidenciada de um maneira quase que generalizada pelas células da polpa dental, tecido conjuntivo periapical e periodontal nos dentes dos animas do grupo controle (Figura 5.3Z), mas não pode ser evidenciado no tecido pulpar de nenhum dente implantado no rim (Figura 5.3V) ou na tíbia (Figura 5.3X). 
Figura 5.3 - Grupo controle e grupo de germes de animais D2 transplantados para os rins e tíbias, com 11 dias de proservação.

Coloração em HE; germe transplantado no rim, aumento de 10x (5.3A); germe transplantado para a tíbia, aumento de $2,5 \mathrm{x}(5.3 \mathrm{~B}), 10 \mathrm{x}\left(5.3 \mathrm{~B}^{\prime}\right)$ e de $40 \mathrm{x}$ $\left(5.3 B^{\prime}\right.$ ' ); germe do grupo controle, aumento de $10 x$ (5.3C). Forte expressão de CD105 no tecido pulpar e periapical, aumento de 10x (5.3F); expressão focal de CD105 nos tecidos pulpar e peridental nos grupos experimentais, aumento de 10x (5.3D e 5.3E). Expressão de VEGF com padrão similar ao CD105, aumento de $10 \mathrm{x}(5.3 \mathrm{G}, 5.3 \mathrm{H}, 5.3 \mathrm{I})$ e $40 \mathrm{x}\left(5.3 \mathrm{H}^{`}\right)$. Expressão de $\mathrm{AML}$ no tecido periodontal, aumento de 10x (5.3L); e em raras células perivasculares, aumento de $10 x$ ( $5.3 \mathrm{~J}$ e $5.3 \mathrm{~K}$ ) e $40 x$ (5.3J'). Forte expressão de PDGFR- $\beta$ no tecido pulpar e periodontal, aumento de $10 \times$ (5.30); moderada e focal expressão de PDGFR- $\beta$ no tecido pulpar, aumento de $10 x$ (5.3N); expressão de PDGFR- $\beta$ restrita a poucas células perivasculares e a poucos odontoblastos, aumento de $10 x(5.3 \mathrm{M}$ e $5.3 \mathrm{~N})$. Expressão de NG2 nos tecidos pulpar e periapical e com mais ênfase nas células perivasculares e odontoblastos ativos, aumento de 10x (5.3R); esporádica expressão de NG2 nas células perivasculares e nos poucos odontoblastos ativos, aumento de $10 \times(5.3 \mathrm{P}$ e 5.3Q). Diminuição da expressão de nestin pelos odontoblastos, aumento de 10x (5.3U); expressão de nestin pelos odontoblastos que estão em aparente atividade, aumento de $10 x$ (5.3S e 5.3T). Maior da expressão de S100 no tecido pulpar, aumento de 10x (5.3Z), ausência da expressão de S100 no tecido pulpar dos grupos experimentais, aumento de $10 x$ (5.3V e 5.3X). 
RIM
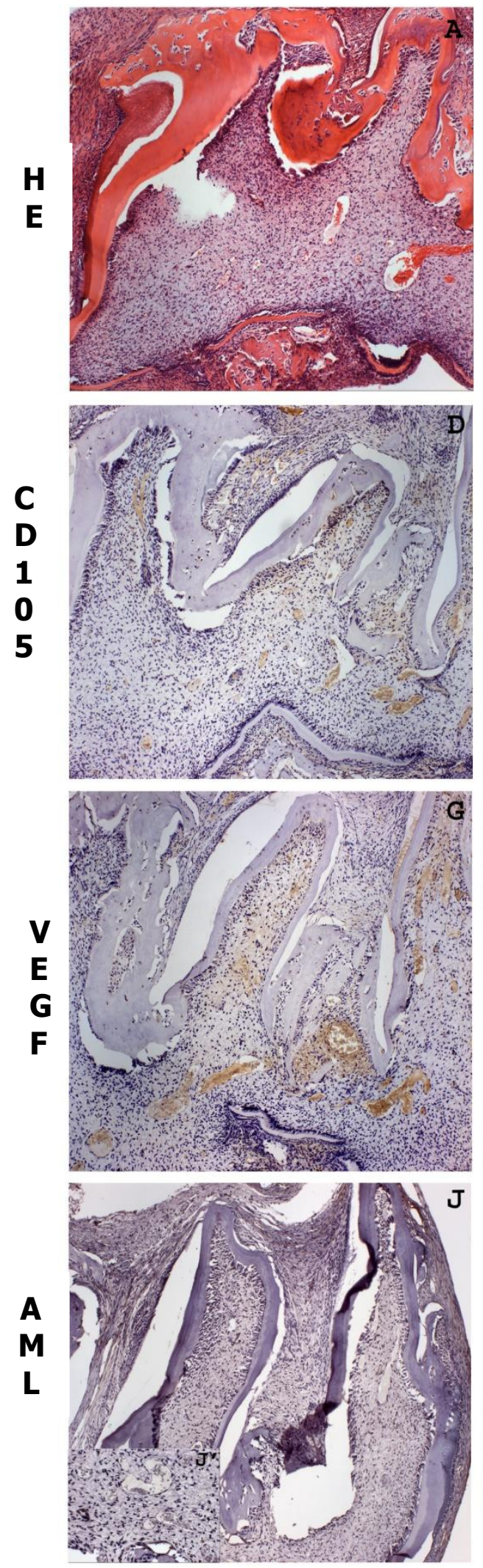

TÍBIA
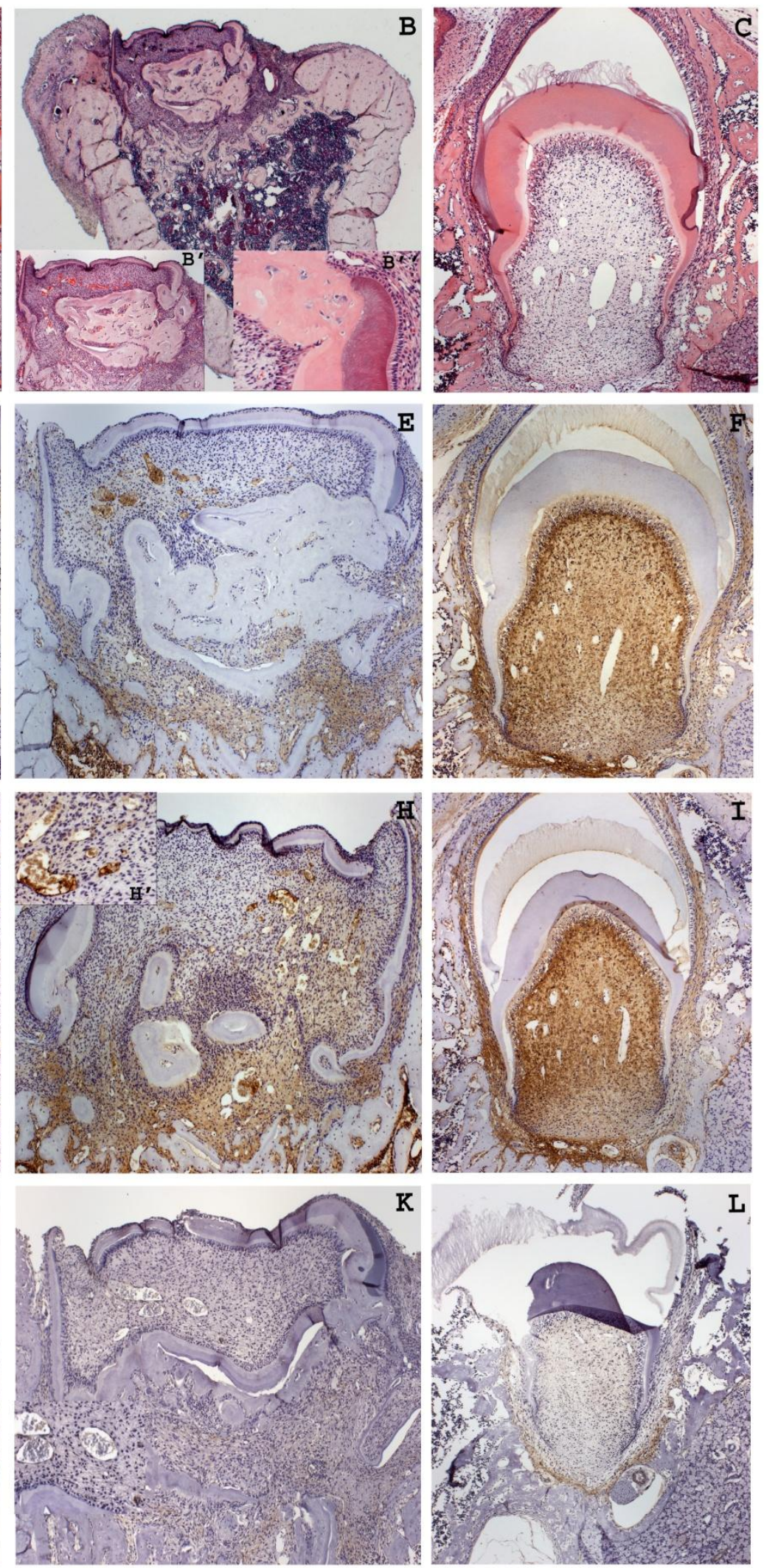


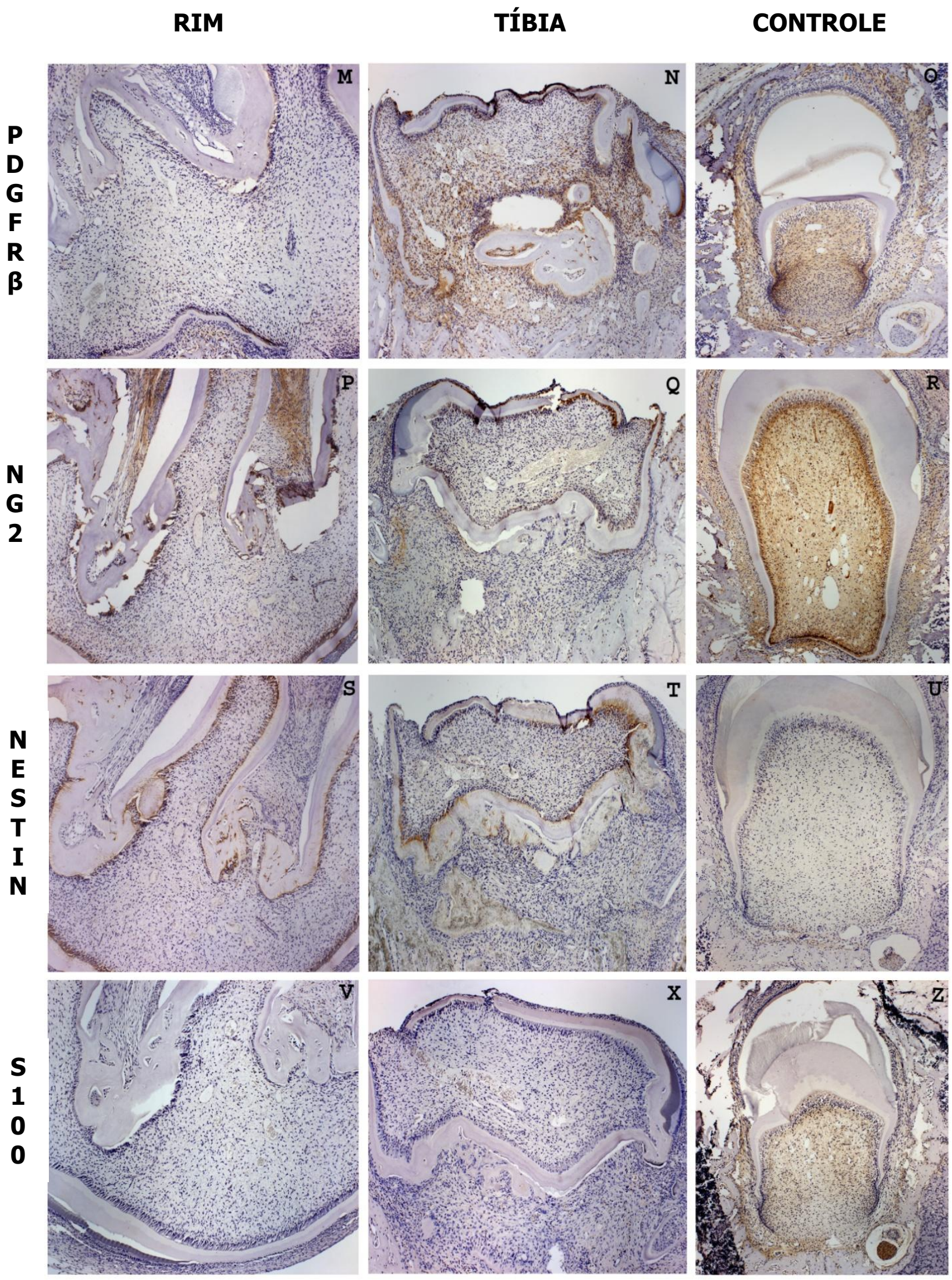




\subsection{Animais que receberam os germes dentais dos doadores com 6 dias de vida pós-natal e com proservação de 3 dias}

O grupo controle para este grupo experimental foi composto pelos germes dentais dos primeiros molares superiores de ratos com 9 dias de vida pós-natal (animais D9 (Figura 5.4C)), uma vez que tal estágio de desenvolvimento dental equivale, em tempo, os 6 dias de desenvolvimento dos germes dentais dos animais com 6 dias de vida pós-natal somados aos 3 dias de desenvolvimento dos mesmos nos seus respectivos sítios de transplante. Vale lembrar ainda que o mesmo grupo de animais D9 também serviu de controle para os experimentos de transplante de germe dental de animais D2, proservados por 7 dias, de tal forma que muitas vezes iremos ser mais sucintos ao descrever os dados desse grupo de experimentos considerando que já foram descritos anteriormente.

Morfologicamente, pode-se observar que os dentes dos animais D6 implantados no rim por 3 dias tiveram o seu desenvolvimento praticamente estagnado após o transplante (Figura 5.4A). A polpa dental encontra-se hipercelularizada na região apical, mas, em contraste, geralmente apresenta-se como um tecido conjuntivo frouxo, edemaciado e hemorrágico na região dos cornos pulpares. Ademais, muitas vezes a camada de odontoblastos não pode mais ser identificada e a bainha radicular de Hertwig estava atrófica, irregular e com áreas de calcificação. Quanto ao esmalte, nota-se que este está ausente em vários pontos ao longo da coroa dental e irregular nos demais. O folículo dental, geralmente, estava atrésico ou ausente e, nesse último caso, coincidentemente a região, o esmalte dental subjacente ou está muito danificado (malformado) ou ausente, dando uma real impressão de que o folículo dental tem um importante papel de proteção na formação/manutenção do esmalte dental. Além disso, foi muito comum a constatação de áreas de necrose na região de fundo de sulco dental, o que deu a impressão que as células dessas regiões não receberam aporte nutritivo adequado. Por fim, pode ser observado, na totalidade dos casos analisados, o início da deposição de material calcificado (dentina reparativa) na porção apical da polpa 
dental como uma aparente tentativa de isolamento do tecido pulpar do meio externo.

Ainda do ponto de vista morfológico, o local de implante dos germes dentais nas tíbias geralmente era circundado por um intenso infiltrado inflamatório agudo, células hematopoiéticas, áreas hemorrágicas e tecido de granulação (Figura 5.4B). Apesar do exemplo mostrado na figura 4B` demonstrar um dente com uma moderada preservação da sua morfologia, a grande maioria dos casos sofreu transformações significativas. A desorganização da camada de odonto e de ameloblastos era nítida (Figura 5.4B”) bem como uma ativa reabsorção dos tecidos mineralizados por células clásticas localizadas externamente aos dentes. Adicionalmente, pode-se observar, comumente, a formação de dentina reparativa, principalmente nas regiões próximas a bainha radicular de Hertwig.

Os imunomarcadores endoteliais VEGF (Figura 5.4G) e CD105 (Figura 5.4D) foram positivos no tecido pulpar da região dos cornos pulpares tanto dos dentes implantados nos rins quanto nas tíbias. Ademais, a positividade pra essas proteínas pode ser evidenciada nos poucos neovasos existentes (Figura 5.4D `) e no tecido conjuntivo do periápice dental. A presença de ambos marcadores foi fortemente evidenciada no tecido de granulação que circunda os dentes implantados nas tíbias.

Não importando o sítio de transplante dos germes dentais, raramente pode-se observar a presença de células de musculatura lisa envolvendo os vasos sanguíneos (Figuras 5.4J), diferentemente do que pode ser observado no grupo controle (Figura 5.4L).

Quanto a expressão de PDGFR- $\beta$, conforme já abordado anteriormente, pode ser evidenciada em todas as células da polpa dental no grupo controle (Figura 5.40) e, de maneira ainda mais expressiva, na camada de odontoblastos e na camada de células subodontoblasticas, além dos pericitos. Apesar da expressão de PDGFR- $\beta$ ser evidente em algumas regiões da polpa dental dos germes implantados nos rins (Figura 5.4M), esta se assemelha muito mais com o grupo controle quando comparado com a polpa dental dos dentes implantados nas tíbias (Figura $5.4 \mathrm{~N}$ ).

A NG2 pode ser nitidamente evidenciada nos pericitos dos vasos sanguíneos dentais e peridentais e, de maneira discreta, porem generalizada, pela 
maioria das demais células da polpa dental, tecido conjuntivo periapical e folículo dental nos germes do grupo controle. Ademais, nota-se que sua expressão é negativa nos odontoblastos que, aparentemente, não estejam em atividade secretora (Figura 5.4R). Esse padrão de expressão é semelhante ao dos dentes implantados na tíbia (Figura 5.4Q), mas diferente dos dentes implantados nos rins (Figura 5.4P). Nestes últimos, a marcação é geralmente restrita aos pericitos, tecido conjuntivo e células do folículo dental, não havendo marcação generalizada no tecido pulpar.

A Nestin pode ser claramente evidenciada em toda a camada de células odontoblásticas que circundam a periferia da polpa dental no grupo controle (Figura 5.4U) o que demonstra, aparentemente, que estas células estão em atividade secretora. A nestin pode também ser visualizada no feixe nervoso localizado lateralmente ao periápice dental e, moderadamente, no tecido conjuntivo do periápice. Contrariamente, tanto nos dentes implantados no rim (Figura 5.4S) quanto os implantados na tíbia (Figura 5.4T), o tecido pulpar parece não expressar mais a nestin, indicando, portanto, uma perda da atividade odontoblástica e inexistência de células de origem nervosa. A ausência de tecido nervoso na polpa dental também pode ser evidenciada pela negatividade de marcação para a proteína S100 (Figuras 5.4V e 5.4X). 
Figura 5.4 - Grupo controle e grupo de germes de animais D6 transplantados para os rins e tíbias, com 3 dias de proservação.

Coloração em HE; germe transplantado no rim, aumento de 10x (5.4A); germe transplantado para a tíbia, aumento de 2,5x (5.4B), 10x (5.4B') e 40x (5.4B ' '); germe do grupo controle, aumento de 10x (5.4C). Expressão de CD105, fraca, mas homogênea, pelas células da polpa dental, aumento de 10x (5.4F); destaque para a marcação específica das células endoteliais, aumento de 40x (5.4D') e pra expressão nas células da polpa dental na região dos cornos pulpares, aumento de 10x (5.4D); distribuição de CD105 ao longo de quase todo o tecido pulpar e tecido de granulação, aumento de 10x (5.4E). Expressão de VEGF similar a CD105, aumento de $10 x(5.4 \mathrm{I}, 5.4 \mathrm{H}$ e $\% .4 \mathrm{G})$ e de $40 \mathrm{x}$ (5.4G'). A AML é evidenciada nas células perivasculares e tecidos peridentais do grupo controle, aumento de 10x (5.4L); e, com muito menor frequência, nas células perivasculares e peridentais dos grupos experimentais, aumento de $10 \mathrm{x}$ (5.4J e $5.4 \mathrm{~K}$ ) e de $40 \times$ ( $\left.5.4 K^{\prime}\right)$. O PDGFR- $\beta$ foi expresso pelas células da polpa dental e, mais intensamente, nas células perivasculares, na camada odontoblástica e subodontoblástica, aumento de 10x (5.40); evidente marcação das células perivasculares e marcação focal do tecido pulpar, aumento de $10 \mathrm{x}$ (5.4M) e de 40x (5.4M'); expressão de PDGFR- $\beta$ similar ao grupo controle, aumento de $10 x(5.4 \mathrm{~N})$. Expressão de NG2 pelas células perivasculares e ausência de positividade nos odontoblastos sem atividade secretora, aumento de 10x (5.4R); evidente marcação das células perivasculares, aumento de 10x (5.4P) e de 40x (5.4P') e distribuição fraca, mas homogênea nas demais células do tecido pulpar, aumento de 10x (5.4Q). Expressão de nestin pelos odontoblastos ativos e, de maneira fraca e difusa, nas demais células da polpa dental, aumento de 10x (5.4U); ausência de positividade para o nestin nos grupos experimentais, salvo por odontoblastos isolados, aumento de 10x (5.4S e 5.4T). Expressão de S100 no feixe nervoso peridental e tecido conjuntivo periapical, aumento de 10x (5.4Z); e ausência de expressão de S100 nos grupos experimentais, aumento de $10 x$ ( $5.4 \mathrm{~V}$ e $5.4 \mathrm{X})$. 

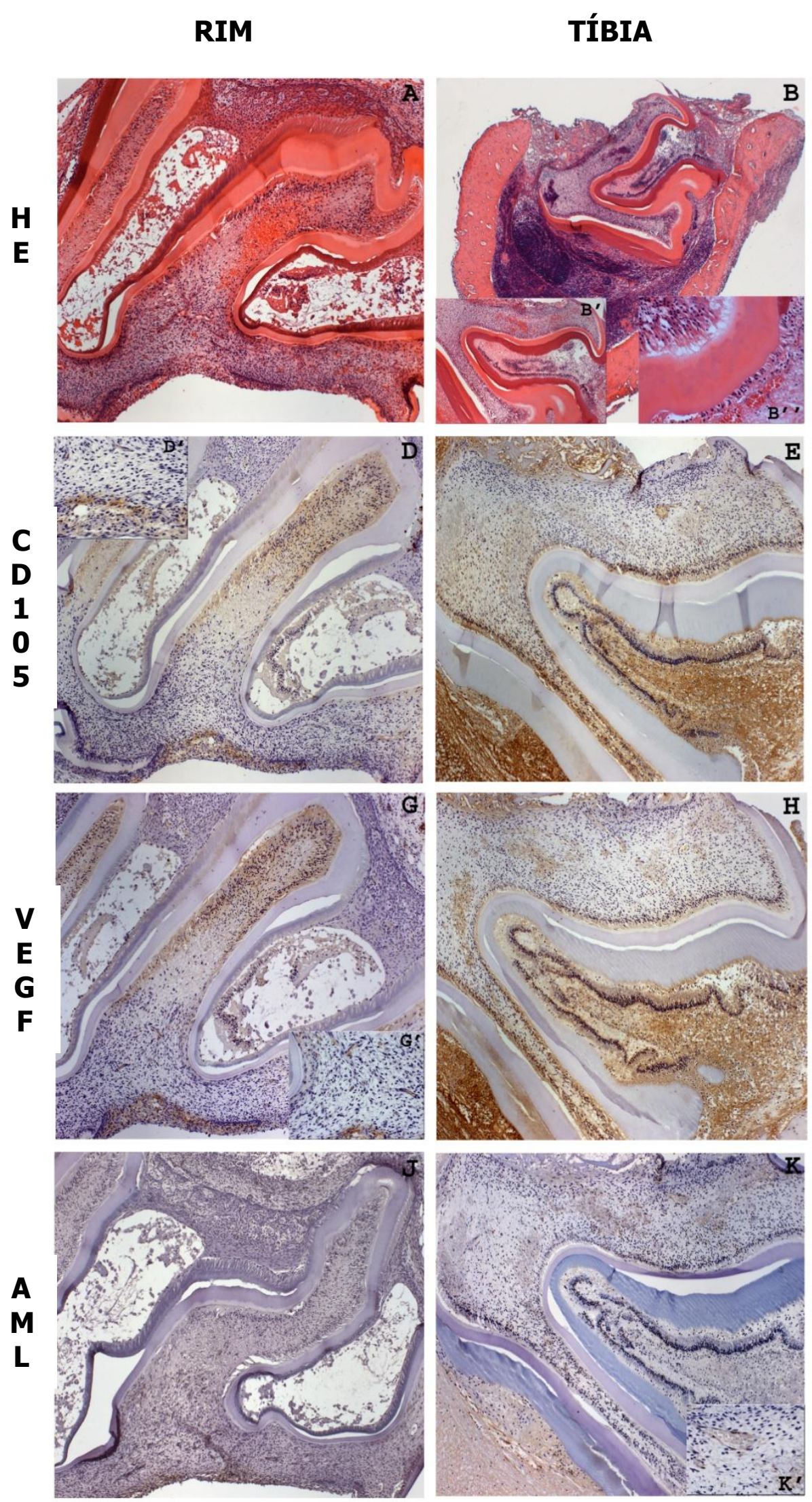

CONTROLE
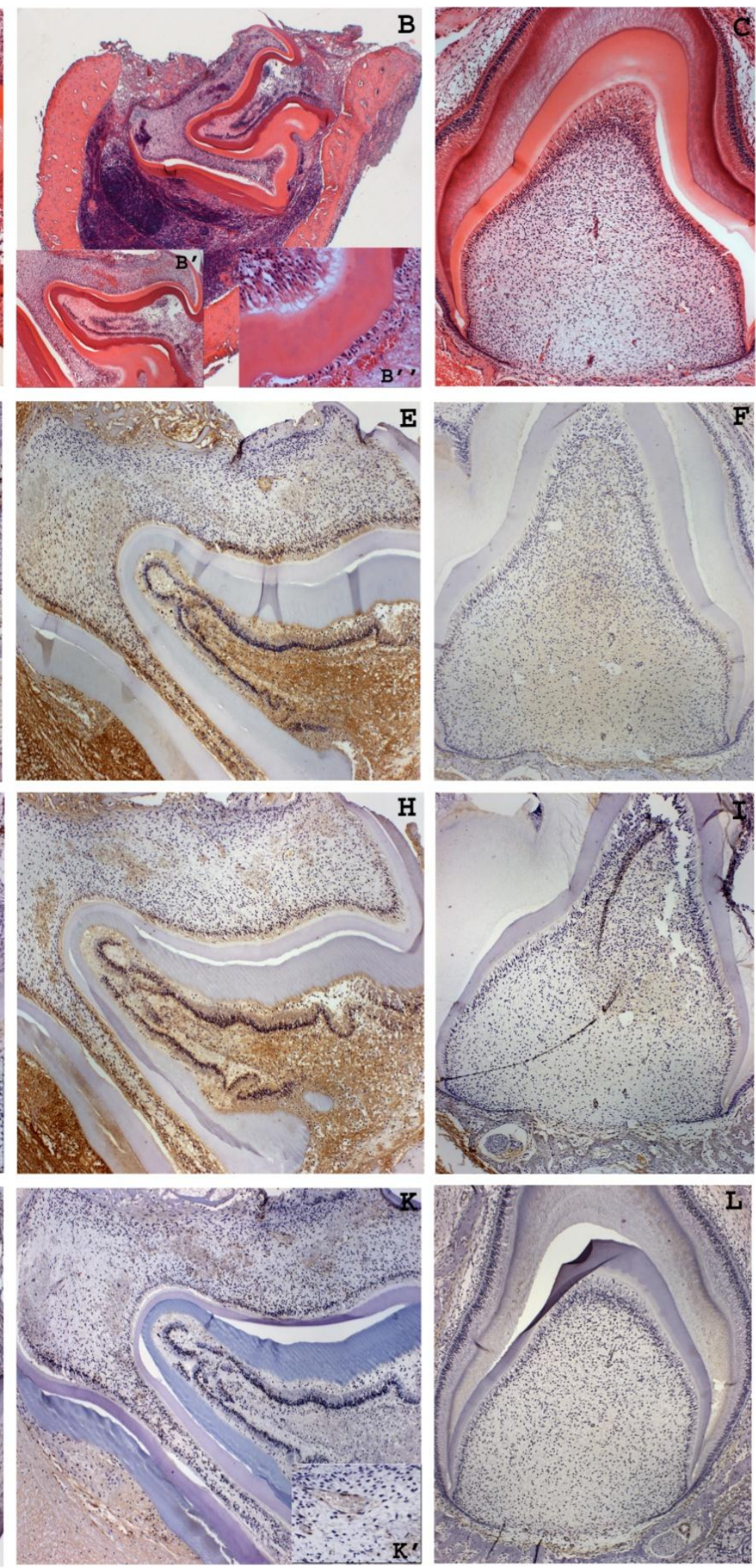
RIM
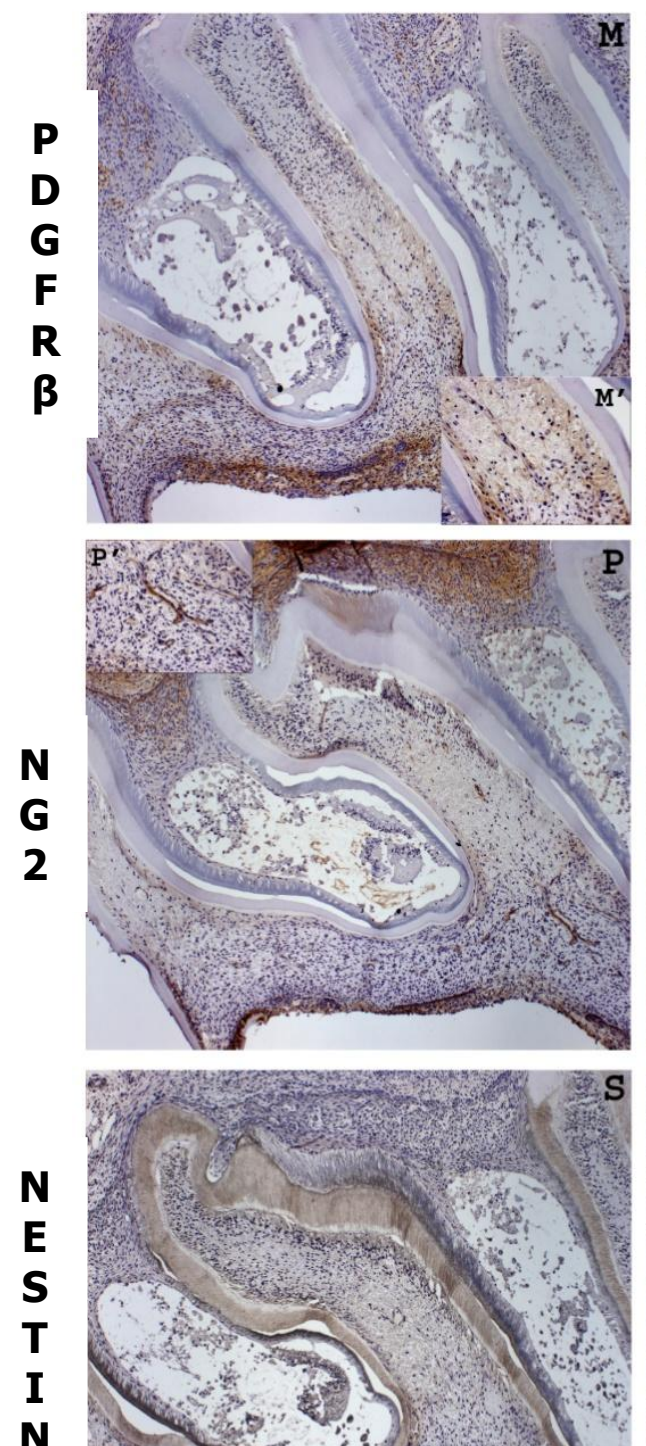

N
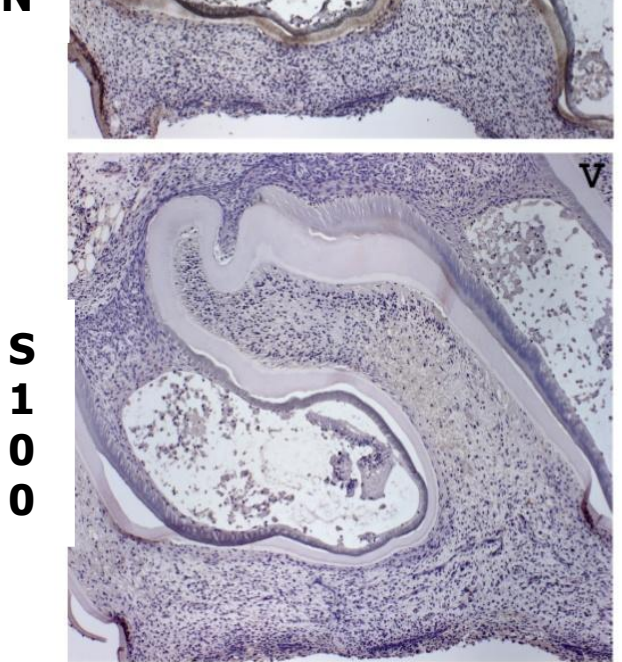

TÍBIA
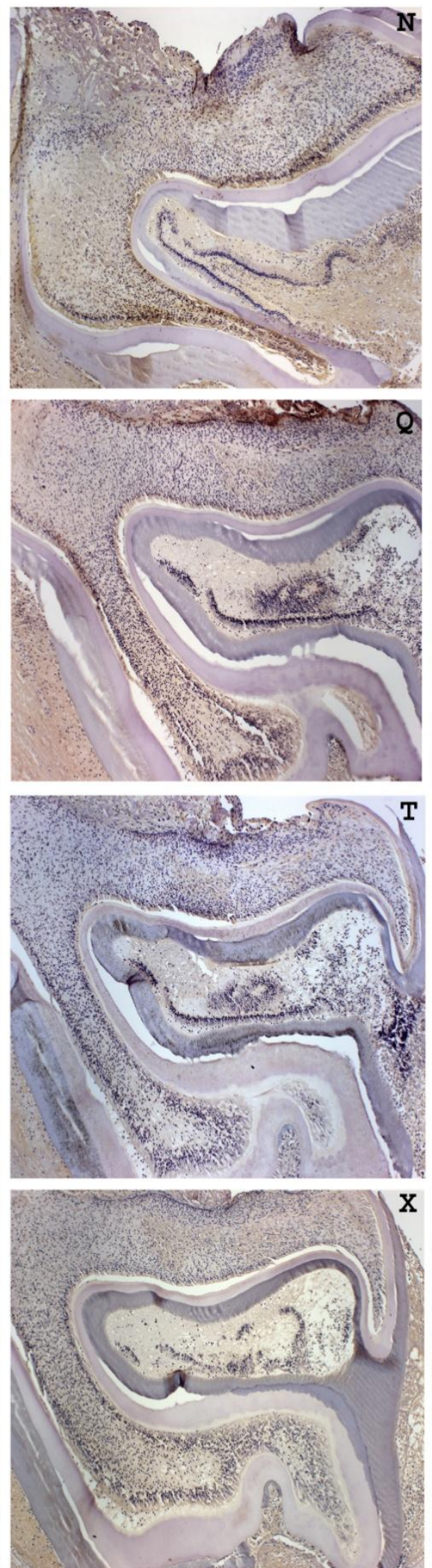

CONTROLE
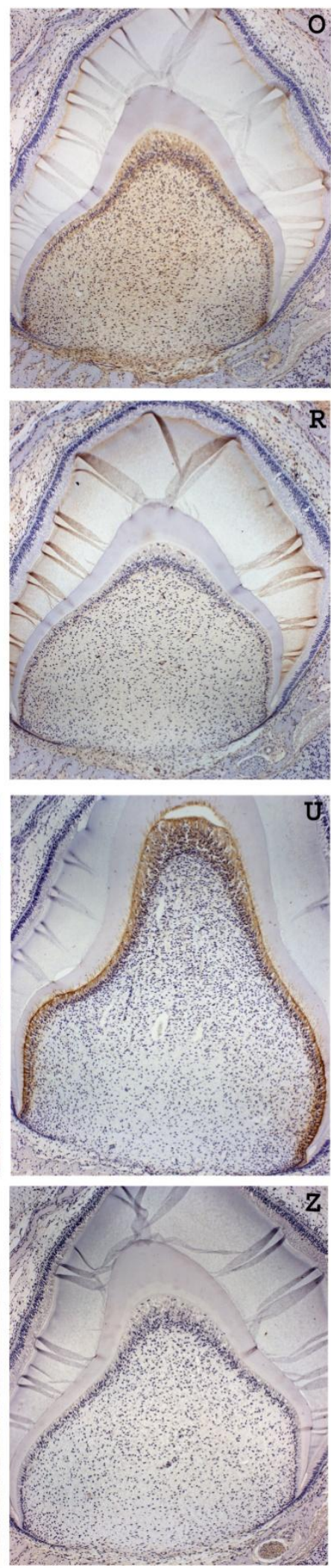


\subsection{Animais que receberam os germes dentais dos doadores com 6 dias de vida pós-natal e com proservação de 7 dias}

Os germes dentais desse grupo experimental tiveram como parâmetro de comparação os germes dentais in loco de animais com 13 dias de vida pós-nata (animais D13). Conforme descrito anteriormente, nesta fase do desenvolvimento, os dentes já possuem a coroa dental completamente formada e raiz em dois terços de formação. Ademais, nota-se deposição de dentina primária e secundária; camada espessa de esmalte sob a coroa dental; camada ameloblastos organizada, porém atrófica; camada de odontoblastos em paliçada; diafragma epitelial bem formado e polpa dental composta por um tecido conjuntivo frouxo ricamente permeado por vasos sanguíneos calibrosos e congestos (Figura 5.5C). Comparativamente, os dentes desenvolvidos sob as capsulas renais possuem uma polpa dental hipercelularizada e, não obstante, com áreas de edema e hemorragia; menor presença de vasos sanguíneos; degeneração/desorganização da camada de ameloblastos e de odontoblastos (Figura 5.5A'); ausência de esmalte sob a coroa dental em vários pontos; atresia do folículo dental; formação de dentina reparativa, principalmente próximo a bainha radicular de Hertwig, bem como na porção apical da polpa dental obliterando, em muitos casos, quase que totalmente a câmara pulpar (Figura 5.5A). Ao sétimo dia pós implante dos germes nas tíbias observa-se uma maior quantidade de tecido de granulação ao redor do dente e uma grande neoformação óssea circunjacente quando comparado com o grupo proservado por apenas 3 dias (Figura 5.5B). A impressão tida ao analisar-se a totalidade dos casos é que os dentes na tíbia são vistos pelo organismo como um corpo estranho e, como tal, o organismo faz o possível para eliminá-lo e/ou dificultar o seu desenvolvimento. Neste sentido, na grande maioria dos casos observava-se a degeneração completa do folículo dental, reabsorção dos tecidos mineralizados por células clásticas. Além disso, a polpa dental comumente encontra-se hipocelularizada, edemaciada, com vasos sanguíneos hiperdilatados e congestos. 0 caso mostrado na figura 5.5B consiste em um dos casos mais bem sucedidos dentre os implantados na tíbia, mostrando pouca alteração da morfologia dental e 
reabsorção apenas inicial do esmalte dental. Comparativamente com os dentes desenvolvidos nos rins, observa-se uma menor formação de dentina reparativa.

Interessantemente, a expressão imunoistoquimica para os marcadores anti-CD105 e anti-VEGF é mais semelhante entre os dentes implantados nas tíbias (Figuras $5.5 \mathrm{E}$ e $5.5 \mathrm{H}$ ) e o grupo controle (Figuras $5.5 \mathrm{~F}$ e $5.5 \mathrm{I}$ ) do que entre os dentes implantados nos rins (Figuras 5.5D e 5.5G) e o mesmo grupo controle. Nos dentes implantados nas tíbias é perceptível que, além da marcação positiva nas células endoteliais, há uma imunoexpressão de CD105 e VEGF pela grande maioria das células da polpa dental e tecido conjuntivo periapical (Figuras 5.5E`e 5.5H`).

A análise imunoistoquimica para AML mostrou que tanto nos dentes implantado nos rins (Figura 5.5J) quanto nos implantados nas tíbias (Fig ura 5.5K), apenas uma pequena proporção dos vasos sanguíneos é circundada por células da musculatura lisa (Figuras 5.5J` e 5.5K'). Nestes casos, também pode ser vista uma moderada marcação positiva no folículo dental e no tecido conjuntivo periapical, tal qual também pode ser evidenciado no grupo controle (Figura 5.5L).

Conforme descrito anteriormente, os germes dentais dos primeiros molares superiores dos animais D13 apresentam uma expressão de PDGFR- $\beta$ (Figura 5.50) e de NG2 (Figura 5.5R) por quase todo o tecido pulpar, periapical e periodontal. Ademias, o NG2 parece estar presente apenas nos odontoblastos em aparente atividade secretora. Comparativamente, o tecido pulpar dos dentes implantados nas tíbias tem um padrão similar de expressão desses marcadores (Figura 5.5N e 5.5Q) ajudando a identificar os raros pericitos presentes no tecido pulpar, mas também se expressando de maneira generalizada no restante do tecido pulpar e no tecido conjuntivo periapical (Figura 5.5N`). Em contrapartida, nos dentes implantados nos rins, a marcação para tais anticorpos também pode ser evidenciada nos pericitos (Figura 5.5M`) mas não está distribuída uniformemente na polpa dental. Vale ressaltar ainda que a NG2 marca com grande intensidade o epitélio interno da bainha radicular de Hertwig, tal qual ocorre no grupo controle (Figuras 5.5M e 5.5P). Para os dentes implantados na tíbia a marcação nesta região, quando existente, é menos intensa.

Ao décimo terceiro dia de desenvolvimento dos dentes in loco, pode-se observar uma diminuição de secreção de matriz dentinária pelos odontoblastos uma 
vez que a coroa dental está completamente formada e a raiz em estágio final de desenvolvimento. Tudo isso reflete em uma menor expressão de nestin nos tecidos dentais, estando agora fracamente expresso na camada de odontoblastos. Ademais, a nestin também está presente no feixe nervoso localizado lateralmente ao periápice e no tecido conjuntivo periapical e periodontal (Figura 5.5U). A presença de nestin pode ser vista em algumas regiões da camada odontoblástica, na maioria dos dentes implantados nos rins, e no tecido conjuntivo periapical e periodontal (Figuras $5.5 \mathrm{~S}$ e $5.5 \mathrm{~S}^{\prime}$ ). Já, nos dentes implantados nas tíbias, a nestin pode ser encontrado, ainda que de maneira singela, apenas no tecido conjuntivo periapical (Figura 5.5T).

A proteína S100, que no grupo controle é evidenciada de maneira generalizada no tecido pulpar, periapical e periodontal (Figura 5.5Z), está ausente na polpa dos dentes implantados no rim (Figura 5.5V) e tíbia (Figura 5.5X), sendo fracamente expressa apenas pontualmente no folículo dental e tecido conjuntivo periapical dos dentes de ambos os grupos. 
Figura 5.5 - Grupo controle e grupo de germes de animais D6 transplantados para os rins e tíbias, com 7 dias de proservação.

Coloração em HE; germe transplantado no rim, aumento de 10x (5.5A) e 40x $\left(5.5 A^{\prime}\right)$; germe transplantado para a tíbia, aumento de $2,5 \mathrm{x}(5.5 \mathrm{~B})$ e $10 \mathrm{x}$ $\left(5.5 \mathrm{~B}^{\prime}\right)$; germe do grupo controle, aumento de $10 \mathrm{x}(5.5 \mathrm{C})$. Forte expressão de CD105 no tecido pulpar e periodontal, aumento de 10x (5.5F); expressão de CD105 no endotélio de vasos sanguíneos, tecido pulpar e de granulação, aumento de $10 x$ (5.5E) e 40x (5.5E'); expressão focal de CD105 no tecido pulpar, aumento de 10x (5.5D). A expressão de VEGF foi similar a do CD105 em todos os grupos analisados, aumento de $10 \mathrm{x}(5.5 \mathrm{G}, 5.5 \mathrm{H}, 5.5 \mathrm{I})$ e $40 \mathrm{x}$ $\left(5.5 \mathrm{H}^{\prime}\right)$. Evidenciação de $\mathrm{AML}$ nas células perivasculares e nos tecidos periodontais, aumento de $10 \mathrm{x}$; (5.5L); diminuição da expressão de $\mathrm{AML}$ nas células perivasculares da polpa dos germes dos grupos experimentais, aumento de $10 x$ ( $5.5 \mathrm{~J}$ e $5.5 \mathrm{~K})$ e $40 x$ (5.5J'e $5.5 \mathrm{k}^{\prime}$ ). Ausência de expressão de PDGFR- $\beta$ nos odontoblastos quiescentes e forte expressão nas células perivasculares e tecido conjuntivo pulpar e periodontal, aumento de 10x (5.50); diminuição da quantidade de células perivasculares PDGFR- $\beta$ positivas e distribuição focal de tal proteína no tecido pulpar, aumento de $10 \times(5.5 \mathrm{M}$ e $5.5 \mathrm{~N})$ e de $40 \times(5.5 \mathrm{M}$ `e $\left.5.5 N^{\prime}\right)$. Expressão de NG2 no tecido pulpar, evidenciando as células perivasculares e os odontoblastos em atividade de secreção de matriz dentinária, aumento de 10x (5.5R); ausência de odontoblastos NG2 positivos na polpa dos dentes implantados nos rins, aumento de 10x (5.5Q) e distribuição focal nos odontoblastos viáveis remanescentes na polpa dos dentes transplantados nas tíbias, aumento de 10x (5.5P). Diminuição da expressão de nestin pelos odontoblastos e marcação difusa e homogênea ao longo da polpa dental e tecido periapical, aumento de 10x (5.5U); ausência de marcação de nestin, aumento de $10 \times(5.5 \mathrm{~T})$, e presença de marçação restrita a áreas com odontoblastos ativos, aumento de 10x (5.5S) e 40x (5.5S`). Expressão de S100 no tecido pulpar e periodontal, aumento de 10x (5.5Z); ausência de expressão de S100 na polpa dental e marcação positiva apenas em células peridentais, aumento de $10 \mathrm{x}$ (5.5V e $5.5 \mathrm{X}$ ) e de $40 \times$ ( $\left.5.5 \mathrm{~V}^{\prime}\right)$. 

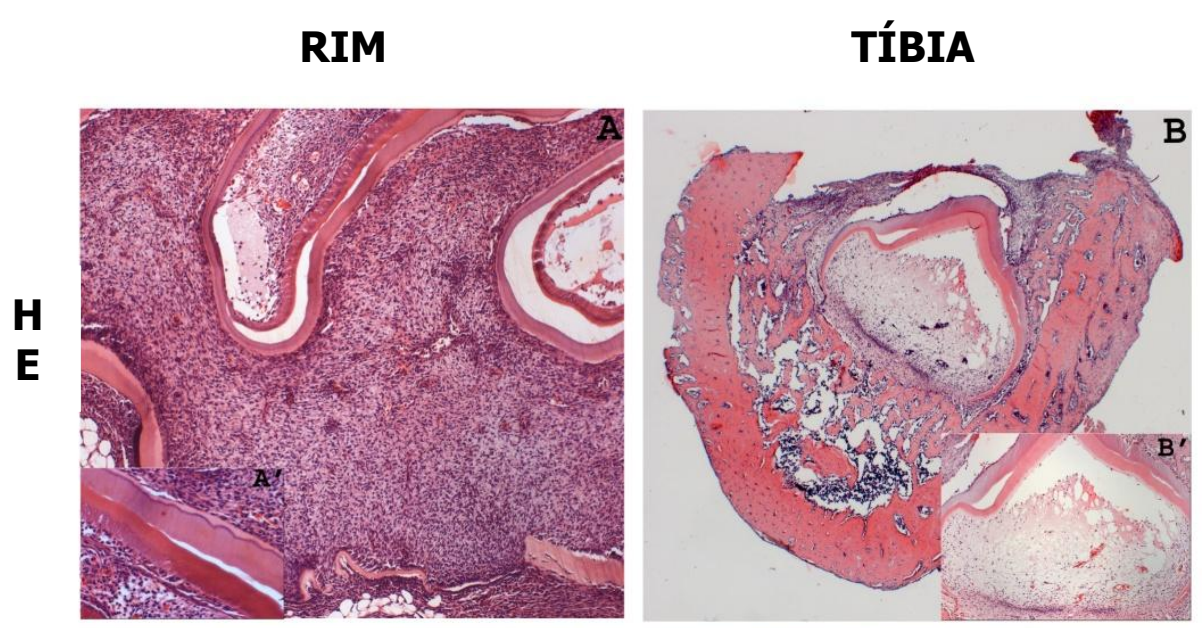

CONTROLE
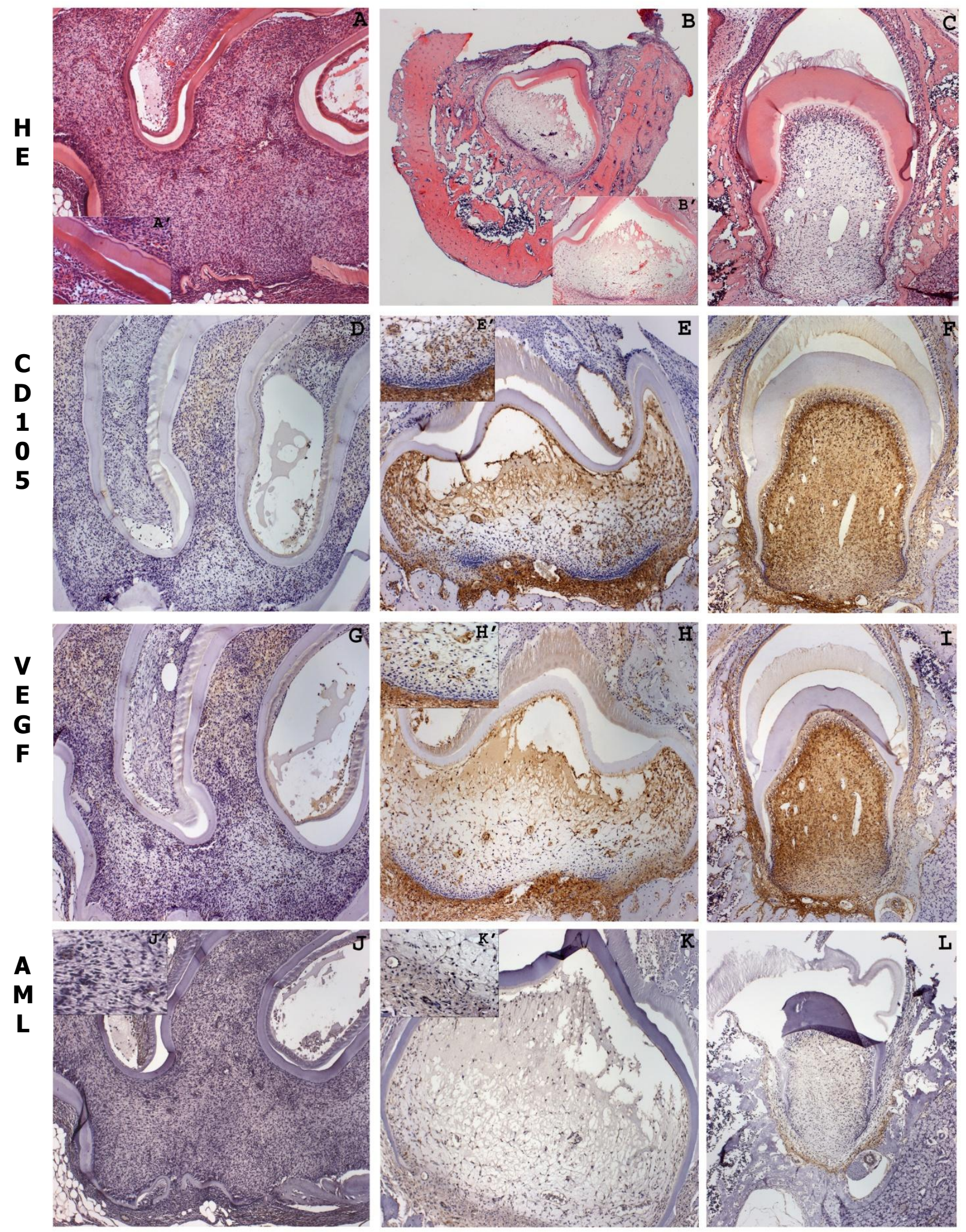

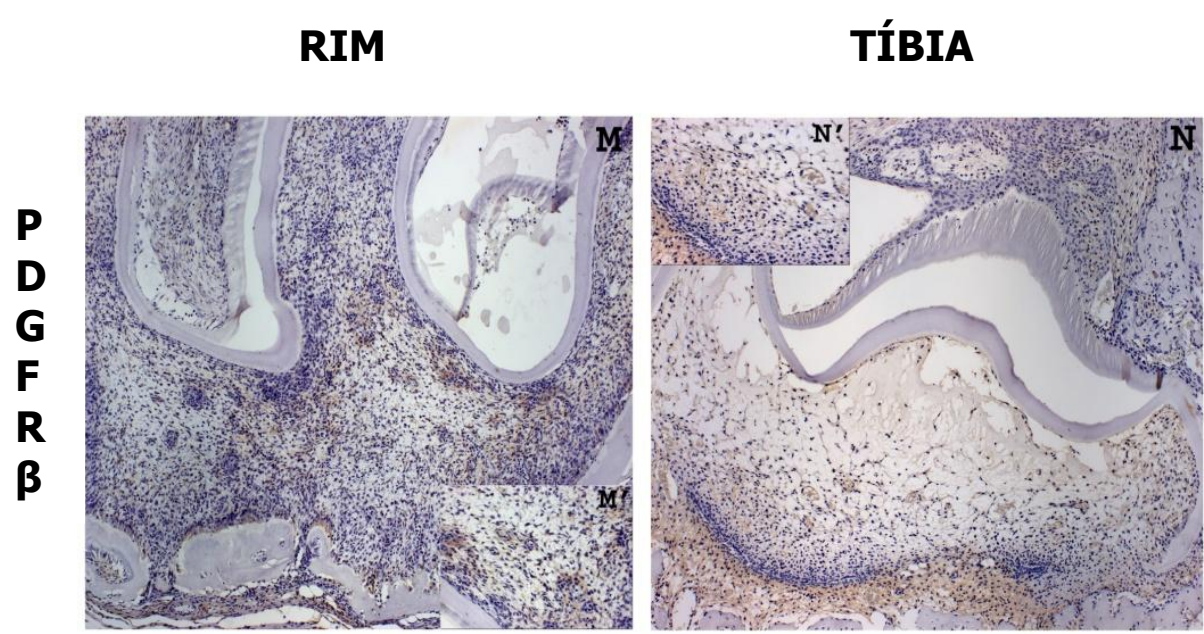

CONTROLE
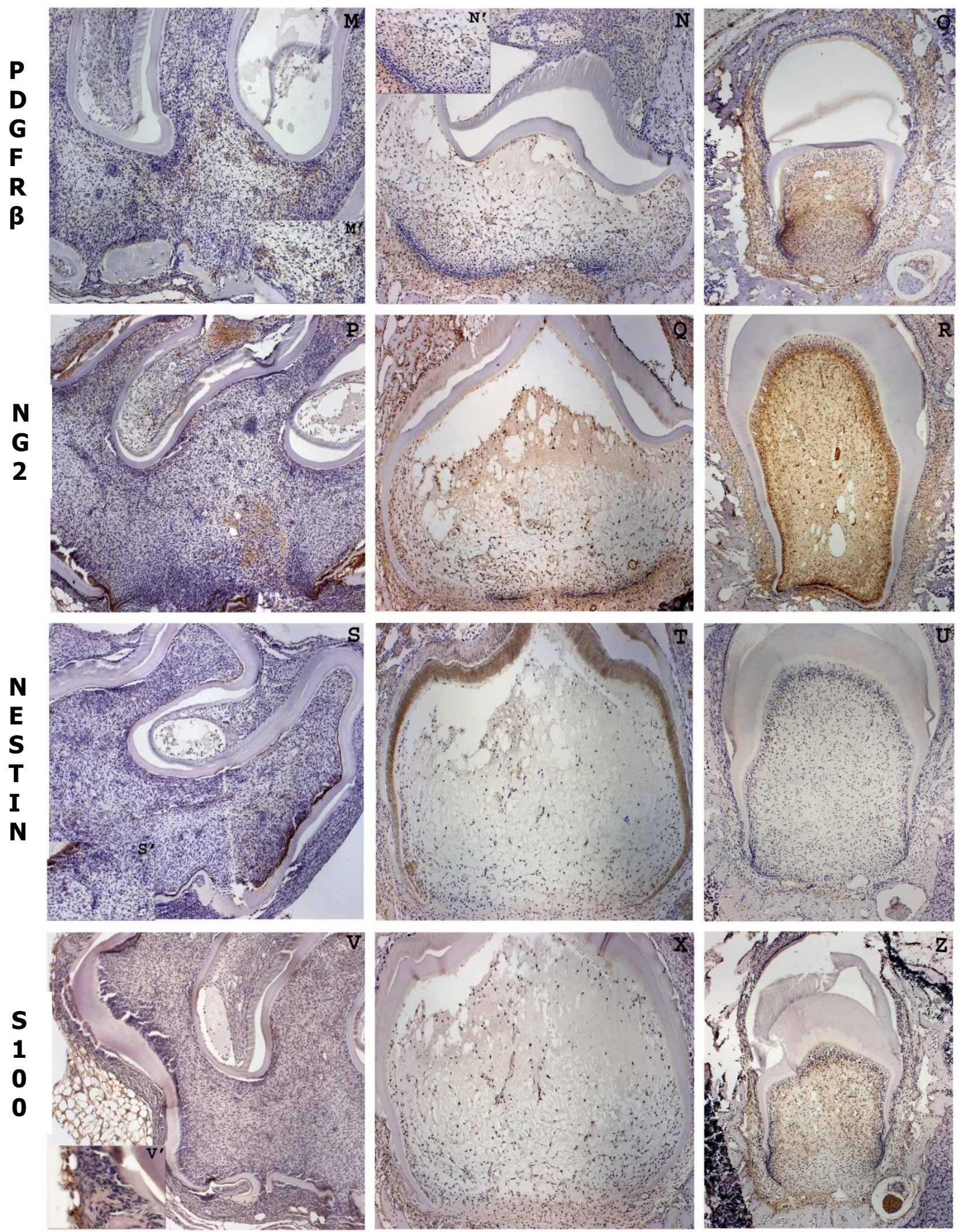


\subsection{Animais que receberam os germes dentais dos doadores com 6 dias de vida pós-natal e com proservação de 11 dias}

Para avaliar comparativamente o desenvolvimento dos germes dentais de animais D6 que foram transplantados por 11 dias para as tíbias ou para os rins, analisou-se os germes dos primeiros molares superiores in loco de animais com 17 dias de vida (animias D17). Nestes casos, pode-se observar dentes em estágio final de desenvolvimento, e, como tal, com uma coroa dental bem formada, composta por uma camada de dentina primária e secundária e revestida externamente por uma camada espessa de esmalte. O tecido pulpar é composto por um tecido conjuntivo frouxo, por uma camada de odontoblastos bem organizado na sua periferia e com vasos sanguíneos calibrosos. Externamente ao dente, pode-se perceber que, sob a coroa dental, a camada de ameloblastos, a pesar de existente, está atrófica, assim como o folículo dental. Circundando a raiz dental nota-se presente um ligamento periodontal sadio, ricamente celularizado e vascularizado. $\mathrm{O}$ diafragma epitelial está presente e a polpa dental está em comunicação com o meio externos apenas por um pequeno óstio na sua porção apical: o forame apical (Figura 5.6C).

Quando analisados os dentes de animais D6 implantados sob as cápsulas renais por 11 dias, observa-se que o esmalte dental foi largamente reabsorvido, na grande maioria dos casos; há uma deposição de dentina reparativa, principalmente próxima a bainha radicular de Hertwig, e deposição de tecido ósseo continuamente à dentina em algumas regiões externas a coroa dental. Em relação a presença de tecido ósseo, é curioso observar a sua formação externamente a coroa dental e, em muitos casos, intensamente na região de fundo de sulco. A polpa dental encontrase, geralmente, ricamente celularizada e com vasos sanguíneos hiperdilatados. Além disso, pode-se observar que a deposição de tecido mineralizado na porção apical do tecido pulpar é ainda mais expressiva nos dentes que se desenvolveram por 11 dias no rins do que os que permaneceram apenas 7 ou 3 dias nesse mesmo sítio de implantação (Figura 5.6A). 
Quando avaliado o desenvolvimento dos germes dentais de animais D6 implantados nas tíbias, com o mesmo tempo de acompanhamento que nos rins, pode-se observar que, na maioria dos casos, os dentes estavam quase que totalmente circundados por trabéculas de tecido ósseo sadio (Figura 5.6B). Conforme já descrito anteriormente para os dentes implantados na tíbia, a impressão que se tem ao analisar todos os casos é que o dente é visto, neste local, como um "corpo estranho" e, portanto, tenta ser reabsorvido/integrado ao organismo. Neste contexto, observa-se uma grande reabsorção (completa em muitos casos) do esmalte dental; formação de tecido ósseo contínuo à dentina e ao esmalte remanescentes, principalmente externamente ao dente, mas, não raramente, também no interior do tecido pulpar. Este último, frequentemente, apresenta-se frouxamente arranjado, com áreas de edema e hemorragia e com vasos sanguíneos hiperdilatados e congestos (Figura 5.6B ').

Quando avaliado a expressão e CD105 e VEGF nos tecidos dentais, foi constatado uma marcação, tanto nos dentes implantados nas tíbias (Figuras 5.6E e $5.6 \mathrm{H}$ ), quanto no grupo controle (Figuras 5.6F e 5.6I) ainda maior do que quando analisados em fases mais precoces do seus desenvolvimentos. No grupo controle $o$ CD105 e o VEGF, além de serem expressos pelos vasos sanguíneos, são fortemente expressos em todo o tecido da polpa dental e ligamento periodontal. Não pode-se observar o desenvolvimento de raiz e, se quer, portanto, o desenovolvimento de ligamento periodontal nos germes transplantados para as tíbias, mas, em contrapartida, os vasos sanguíneo (Figura 5.6H') e o tecido pulpar parecem expressar CD105 e VEGF com intensidade muito similar aos dentes desenvolvidos in loco (Figura 5.6H). Para os dentes implantados nos rins, esses mesmos imunomarcadores são expressos apenas por alguns vasos sanguíneos (Figuras 5.6D 'e 5.6G') e estão presentes somente em algumas regiões do tecido pulpar e periapical (Figuras 5.6D e 5.6G).

A utilização de anticorpos anti-AML nos permitiu identificar AML não somente abluminalmente a vasos sanguíneos dentais e peridentais, mas também, em quantidade moderada, em todo tecido conjuntivo periodontal dos dentes do grupo controle (Figura 5.6L). Os vasos sanguíneos da polpa dos dentes implantados nos rins, embora em sua minoria, também mostraram ter células de musculatura 
lisa envolvendo-os (Figura 5.6 ' '). Ademais, pode ser notada a presença de AML em algumas regiões do tecido pulpar (principalmente nos cornos pulpares) e no tecido conjuntivo que envolve tais dentes (Figura 5.6J). Nos dentes implantados nas tíbias, a AML está presente em uma proporção maior de vasos sanguíneos (Figura 5.6K`) e interessantemente, de maneira quase que generalizada pelo tecido conjuntivo pulpar e peridental (Figura 5.6k).

No grupo controle, o PDGFR- $\beta$ foi expresso pelos pericitos e, de uma maneira geral, pelo tecido conjuntivo da polpa dental, ligamento periodontal e folículo dental (Figura 5.60). Nos dentes transplantados para os rins, o PDGFR- $\beta$ revela uma menor freqüência de pericitos adjacentes as células edoteliais e um padrão de distribuição menos homogêneo ao longo do tecido conjuntivo pulpar e peridental (Figura 5.6M). Os dentes implantados nas tíbias tem uma intensidade e uma homogeneidade da marcação do PDGFR- $\beta$ muito semelhantes ao grupo controle (Figura $5.6 \mathrm{~N}$ ).

A NG2 apresentou um padrão de expressão muito semelhante ao PDGFR- $\beta$, tanto nos grupos controles (Figura 5.6R) quanto nos dentes implantados nas tíbias (Figura 5.6Q). Já nos dentes implantados nos rins (Fig 5.6P), a NG2 marcou, além dos pericitos, os odontoblastos ativos (Figura 5.6P').

Ao décimo sétimo dia vida pós-natal, os germes do grupo controle mostram uma forte expressão nestin na camada de célula odontoblásticas e nos feixes nervosos adjacentes aos dentes e, em menor intensidade, expressão de nestin pelo tecido conjuntivo pulpar e periodontal (Figura 5.6U). Nos dentes implantados nos rins, em decorrência da degeneração da camada de odontoblastos, o nestin pode ser visto em apenas alguns pontos da periferia da polpa dental (Figura 5.4S) evidenciando, fortemente, os odontoblastos, sejam os que estejam produzindo dentina secundária os que estejam produzindo dentina terciária (Figura $5.4 S^{\prime}$ ) e ostodentina. Ademais, a nestin também pode ser vista em diversas regiões da polpa dental e tecido conjuntivo peridental. Nos dentes implantados nas tíbias, a falta de expressão de nestin pelas células da periferia da polpa dental revela a completa degeneração da camada de odontoblastos, na grande maioria dos casos, mas similarmente ao que acontece no grupo controle e, diferentemente do que 
acontece na polpa dos dentes implantados nos rins, a polpa dos dentes implantados nas tíbias, bem como o tecido conjuntivo peridental, apresentam uma moderada e uniforme expressão de nestin.

A proteína S100 pode ser fortemente notada nos feixes nervosos localizados próximo ao periápice dental nos dentes do grupo controle, moderadamente intensa no tecido periodontal e, fracamente expressa na polpa dental (Figura 5.6Z). Para os dentes implantados nos rins, encontrou-se positividade para a S100 apenas nas células mioepiteliais que circundam o germe (Figura 5.6V). Já, para os dentes implantados nas tíbias não só as células do tecido conjuntivo peridental mostraram positividade para tais proteínas, como também o tecido pulpar, de uma maneira fraca e generalizada. 


\section{Figura 5.6 - Grupo controle e grupo de germes de animais D6 transplantados para os rins e tíbias, com 11 dias de proservação.}

Coloração em HE; germe transplantado no rim, aumento de 10x (5.6A); germe transplantado para a tíbia, aumento de 2,5x (5.6B) e 10x (5.6B'); germe do grupo controle, aumento de 10x (5.6C); Forte expressão de CD105 no tecido pulpar e periodontal, aumento de 10x (5.6F); expressão de CD105 no tecido da polpa dental e tecido de granulação adjacente ao germe transplantado, aumento de 10x (5.6E); expressão de CD105 restrita às células endoteliais e à areas focais do tecido pulpar, aumento de $10 x(5.6 \mathrm{D})$ e de $40 \mathrm{x}$ (5.6D'). Expressão de VEGF seguindo o mesmo padrão já descrito para o CD105, aumento de $10 \times(5.6 \mathrm{G}, 5.6 \mathrm{H}$ e $5.6 \mathrm{I})$ com maior detalhe para a imunomarcação das células endoteliais, aumento de 40x (5.6G 'e 5.6H'). Expressão de AML por células perivasculares e pelo tecido periodontal, aumento de $10 \mathrm{x}$ (5.6L); presença de células AML positivas de maneira difusa e, em maior concentração, abluminalmente aos grandes vasos sanguíneos, aumento de $10 x(5.6 \mathrm{~K})$ e de 40x (5.6K'); escassa expressão de AML no tecido pulpar, mas evidente expressão pelas células perivasculares, aumento de 10x (5.6J) e de 40x (5.6J '). Forte expressão de PDGFR- $\beta$ pelo tecido pulpar e periodontal, aumento de $10 \mathrm{x}$ (5.60); expressão de PDGFR- $\beta$ pelo tecido pulpar e, focalmente, nas adjacências, aumento de 10x (5.6N); expressão de PDGFR- $\beta$ em regiões focais do tecido pulpar, aumento de 10x (5.6M). Evidente expressão de NG2 no tecido periapical e periodontal, mas ausência de expressão nos odontoblastos senescentes, aumento de 10x (5.6R); expressão fraca e difusa de NG2 na popa dental e pelas poucas células em aparente de atividade de deposição de tecido mineralizado, aumento de 10x (5.6Q); número expressivo de odontoblastos NG2 positivos, assim como de células perivasculares, aumento de 10x (5.6P) e 40x (5.6P'). Expressão moderada de nestin pelos odontoblastos, tecido pulpar e periodontal, aumento de 10x (5.6U); expressão difusa de nestin pelo tecido pulpar, aumento de 10x (5.6T); expressão de nestin em um grande número de odontoblastos ativos remanescentes, aumento de $10 \times(5.6 S)$ e de $40 \times\left(5.6 S^{\prime}\right)$. Expressão de S100 pelo feixe nervoso periapical, tecido periodontal e, fracamente, pelo tecido pulpar, aumento de 10x (5.6Z); Expressão difusa de 
S100 no tecido pulpar, aumento de 10x (5.6X); ausência de positividade para a proteína S100, no tecido pulpar, aumento de 10x (5.6V). 
RIM
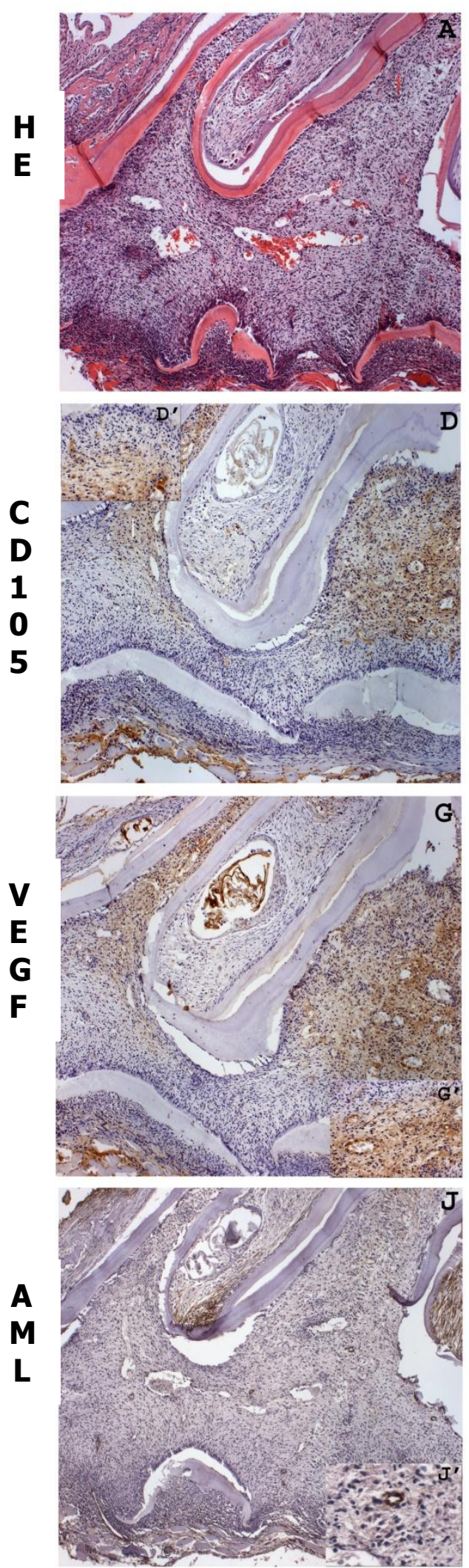

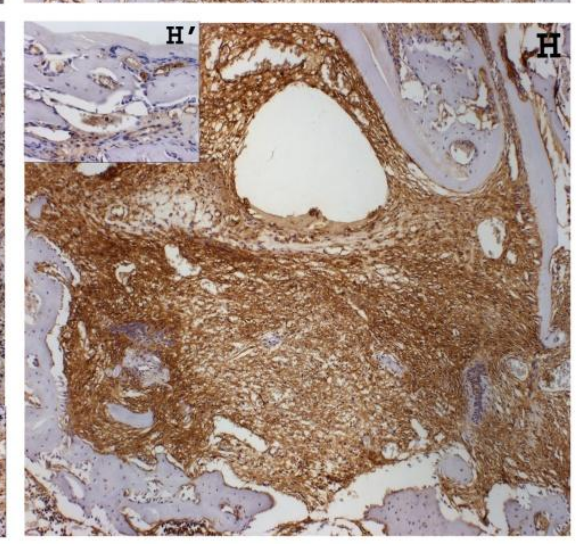

TÍBIA
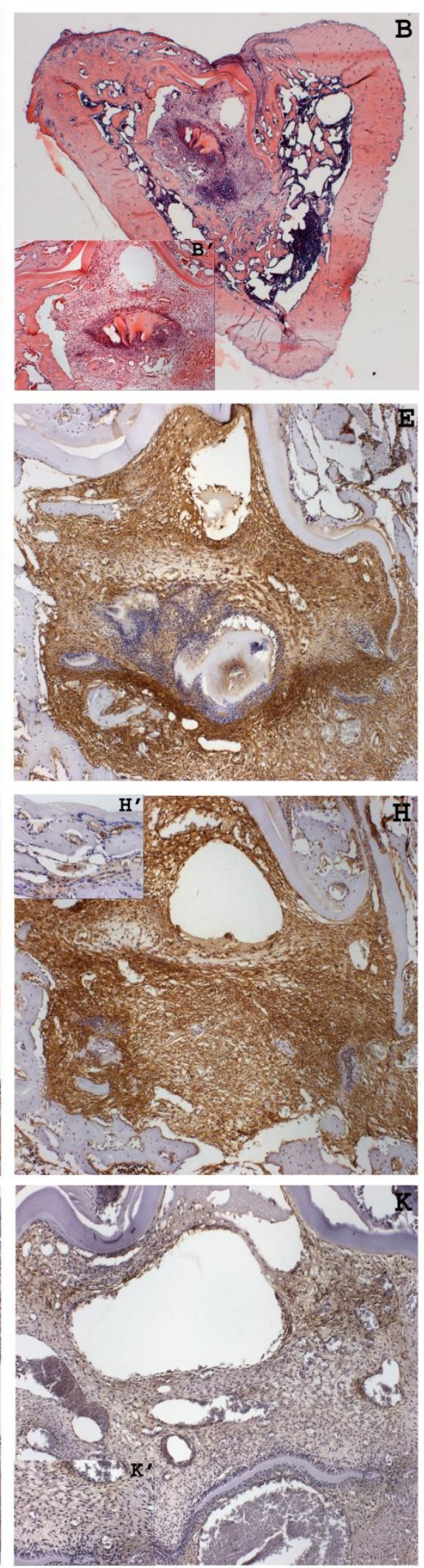

CONTROLE
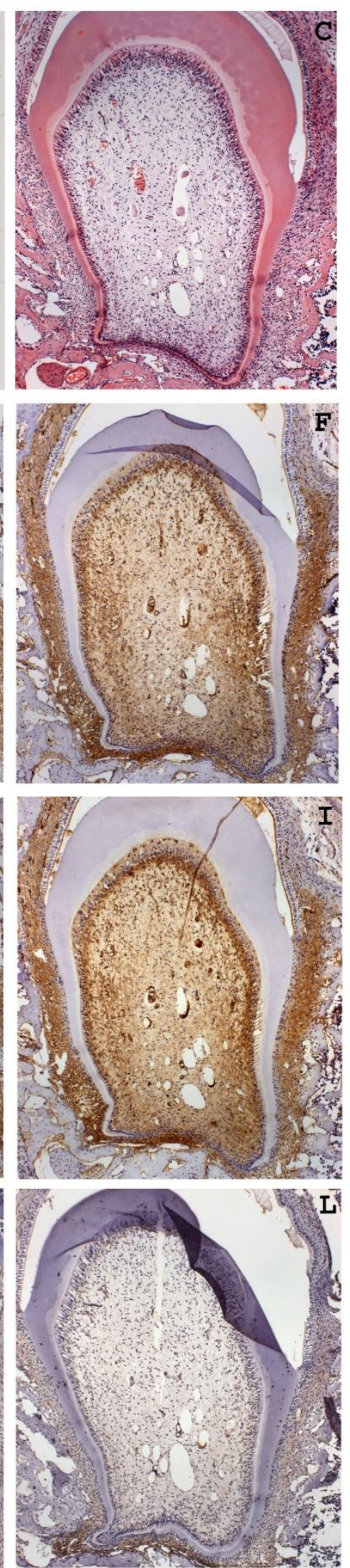


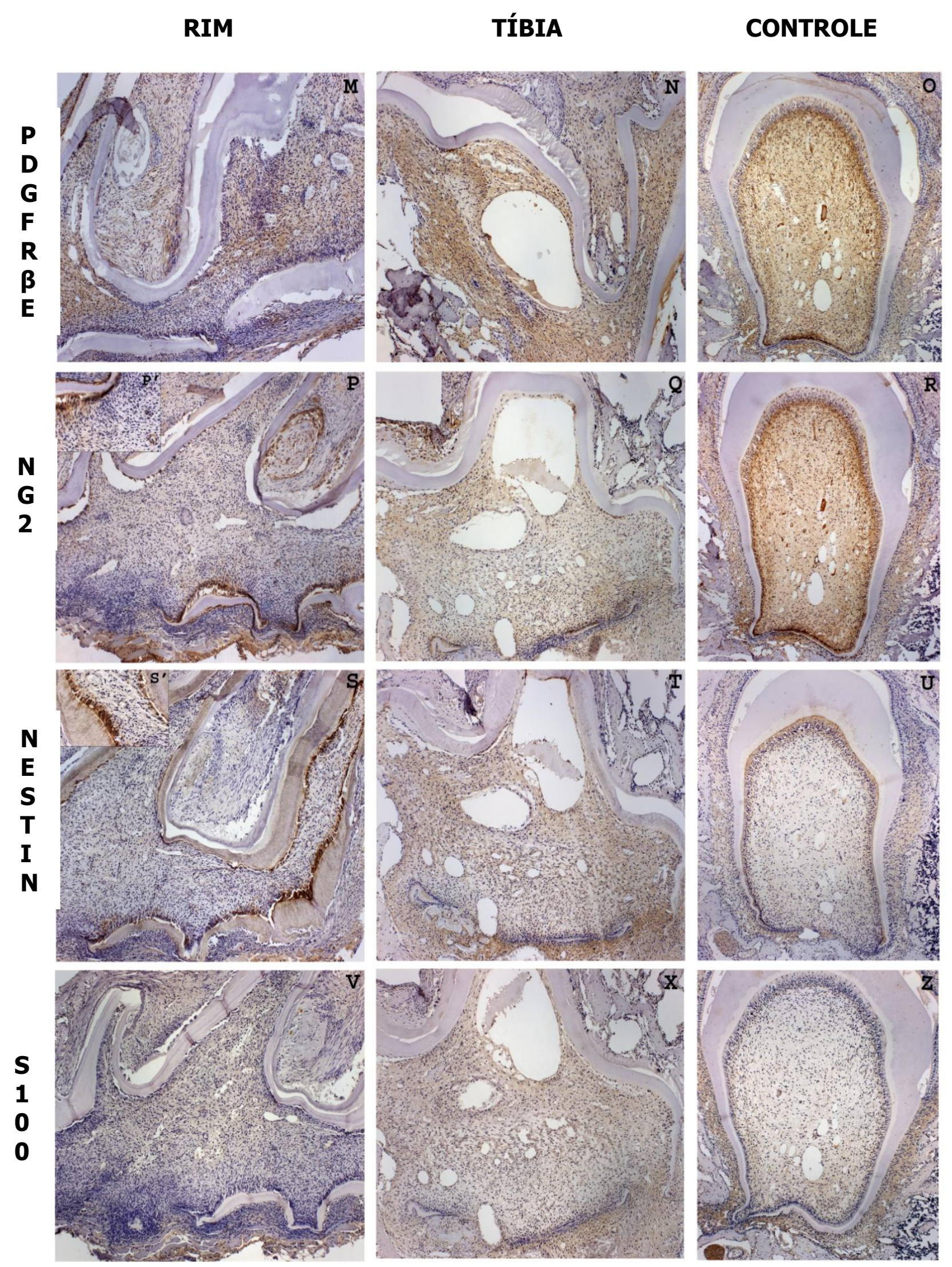


Discussão 


\section{DISCUSSÃO}

A polpa dental é um tecido conjuntivo frouxo, cercado por dentina, e que preenche $o$ interior dos dentes. Nela, podem ser identificados três principais zonas: (I) a camada de odontoblastos, na periferia; (II) a camada sub-odontoblástica, formada por uma zona pobre e uma rica em células e; (III) a zona central. A maioria das células da zona central são fibroblastos, apesar dela conter também células ectomesenquimais indiferenciadas, células do sistema imune, vasos sanguíneos e nervos [115].

Os odontoblastos são as células responsáveis pela produção de dentina e possuem a mesma origem embrionária da polpa dental. A deposição de matriz dentinária pelos odontoblastos se dá quando as células da periferia da papila dental se diferenciam em odontoblastos, os quais, por vezes, sofrem uma polarização nuclear e sintetizam novas organelas [116].

Embora o mecanismo de formação de dentina primária e secundária seja relativamente bem conhecido, aspectos inerentes a formação de dentina terciária ainda são pobremente esclarecido [117].

Sabe-se que a dentina terciária pode ser do tipo reacional ou reparativa e que estas são formadas por diferentes tipos celulares: a dentina reacional é produzida por odontoblastos ao longo de toda a vida do dente e a dentina reparativa seria aquela produzida por novos odontoblastos, recém diferenciados, em resposta a uma injúria $[116,118]$. Além disso, enquanto que a dentina reacional contem túbulos dentinários contíguos aos túbulos dentinários préexistentes na dentina secundária, a dentina reparativa apresenta um aspecto osteóide - o que lhe confere o nome de osteodentina - com células semelhantes a osteócitos aprisionadas em lacunas e com uma matriz circundante rica em osteopontina [118].

A deposição de dentina terciária pode ser notada em todos os casos em que os dentes foram transplantados para os rins e a quantidade de tecido formado foi diretamente proporcional ao tempo de permanência do dente no sítio receptor. Nestes dentes, a maior deposição de dentina terciária ocorreu na região apical do 
tecido pulpar (entre a polpa e o meio externo), e na região da bainha radicular de Hertwig. Não obstante, em grande parte dos casos - principalmente os com maior tempo de proservação - chegou a predominar em quantidade de dentina terciária em relação à primária e a secundária. Interessantemente, o desenvolvimento deste tecido deu-se tanto em direção ao interior do tecido pulpar quanto em direção ao meio externo do dente. Nos dentes implantados nas tíbias, raramente foi observado a formação de dentina reparativa e mesmo quando presente, estava em quantidade muito menor que nos dentes implantados nos rins.

A habilidade que os odontoblastos têm de responder a injúria, mediante regulação da sua atividade secretora e consequente deposição de dentina reacional, é uma característica bem descrita na literatura [119]. No processo de formação de dentina reacional não existe renovação celular, ou seja, a dentina reacional é secretada pelos odontoblastos sobreviventes a agressão $[115,120]$. Contrariamente, o processo de formação da dentina reparativa é, por definição, aquele que é produzido por odontoblastos recém diferenciados. Nestes casos, acredita-se que a magnitude da injúria foi tamanha que resultou na morte dos odontoblastos pré-existentes, mas que se mínimas condições de desenvolvimento são oferecidas às células viáveis remanescentes, estas se diferenciam em novos odontoblastos com capacidade reparadora $[115,120]$.

Baseado no supra-exposto acreditamos que a menor deposição de dentina reacional e reparativa nos dentes implantados na tíbia, não só é um indicativo de que os odontoblastos da polpa dental não permaneceram viáveis após implante neste sítio, assim como também não são oferecidas condições necessárias para que as células viáveis remanescentes na polpa dental se diferenciem em novos odontoblastos e secretem matriz dentinária.

Outro ponto interessante a ser discutido foi que, proporcionalmente ao tempo de transplante, foram evidenciadas inúmeras células multinucleadas fazendo reabsorção ativa (tanto do esmalte quanto da dentina) somente nos dentes implantados nas tíbias. Esse tipo de célula reabsortiva é comumente denominada pela literatura de célula clástica, independentemente do tecido sobre o qual elas estejam agindo (ósseo, dentinário, cartilaginoso, por exemplo) [121]. Tais células são derivadas de precursores mononucleares da linhagem de 
monócitos/macrófagos e se dirigem a superfície dos tecido mineralizados [122] sendo então responsáveis pela degradação da matriz extracelular calcificada nos mesmos [121].

As células clásticas podem ser observadas em várias condições fisiológicas como, por exemplo, na remodelação do tecido ósseo, na erupção dental, no controle dos níveis séricos de íons cálcio e na cicatrização de fraturas; bem como em condições patológicas como a osteoporose, a osteoartrite e em metástases ósseas [121, 122]. Tais células não foram evidenciadas agindo sobre os dentes implantados nos rins.

Conforme abordado anteriormente, qualquer injúria à polpa dental resulta em regeneração dentinária do tipo terciária, seja produzindo dentina reacional ou reparativa $[119,120]$. A angiogênese (ou neovascularização) é um ponto crucial do processo de cicatrização em todos os tecidos e, na da polpa dental, é um prérequisito para a formação de dentina terciária em quaisquer circunstâncias [120].

O fator vascular de crescimento endotelial (VEGF) é considerado mediador primário da angiogênese [123] e desempenha importantes funções biológicas, tais como aumento da permeabilidade celular [124-126] e promoção de quimiotaxia para monócitos [127]. Ademais, pode-se dizer que o VEGF também está envolvido tanto nos processos de reabsorção de tecido ósseo (estando presente nos osteoclastos) $[128,129]$ quanto nos processos de neoformação $[130,131]$.

A angiogênese pode por si só aumenta a severidade do processo inflamatório devido ao aumento do transporte de células inflamatórias, nutrientes e oxigênio ao local inflamado [132]. Além disso, há um aumento do número de células endoteliais que podem, por sua vez, causar um aumento de expressão de diferentes citocinas, moléculas de adesão e outros fatores inflamatórios produzidos por elas mesmas [132]. A expressão de VEGF, em particular, pode ser mediada por muitos mediadores inflamatórios, a exemplo das prostaglandinas, interleucina-6, interleucina-1 [133-135], PGE2 e fator de necrose tumoral-alfa [136, 137] muitos dos quais já foram descritos na polpa dental [133-135].

Estudos pregressos analisaram a expressão de VEGF em dentes com polpa saudável e dentes com pulpite irreversível. Em ambos os casos, $100 \%$ dos vasos sanguíneos mostraram forte positividade citoplasmática para o VEGF. O estroma 
pulpar foi moderadamente marcado na maioria dos casos, em ambos os grupos, e essa marcação se estendeu a maior parte do tecido pulpar. Os odontoblastos foram sempre negativos e as células do infiltrado inflamatório presentes na polpa dos dentes com pulpite irreversível foram fortemente positivas [63].

Em nosso caso, observamos que até o quinto dia de vida pós-natal o VEGF pode ser evidenciado somente nas células endoteliais dos vasos sanguíneos dentais e peridentais e no plexo de tecido conjuntivo periapical, do grupo controle. A medida que os dentes seguem o seu desenvolvimento, a expressão de VEGF se torna cada vez mais evidente nos fibroblastos da polpa dental. Assim, como Artese (2002), acreditamos que a presença de VEGF nos tecidos saudáveis provavelmente pode ser relevante para a angiogênese fisiológica da polpa dental [63].

O padrão de expressão de VEGF na polpa dental dos dentes implantados nas tíbias se assemelhou muito ao dos grupos controles, deixando evidente também que nos dentes com mais inflamação a expressão era ainda maior, o que corrobora com os achados na literatura. Já, para os dentes implantados nos rins, a expressão de VEGF ficou quase que sempre restrita ao endotélio dos vasos sanguíneos; fato este que pode ser explicado por duas coisas: que a polpa dos dentes implantados nos rins perde gradativamente o seu potencial angiogênico e que a presença de infiltrado inflamatório neste dentes é quase sempre muito menor que os implantados nas tíbias.

Outro trabalho bastante interessante e que vale, portanto, ser citado, buscou entender se, mediante aplicação de forças ortodônticas sob os dentes, em modelo animal, ocorreria uma mudança na organização da vasculatura nos tecido periodontais e se esta alteração vascular poderia estar correlacionada à alterações no padrão de expressão de VEGF. O que pode ser evidenciado neste trabalho é que - VEGF é expresso tanto pelas células endoteliais quanto pelos osteoblastos e fibroblastos presentes no ligamento periodontal, em ambos os grupos analisados (dentes submetidos a forças ortodônticas e os não submetidos (grupo controle)). Ademais, os autores observaram que, no grupo experimental, as áreas de maior compressão do ligamento periodontal, onde muitas vezes eram evidenciadas áreas de necrose e hialinização, expressavam muito mais fortemente o VEGF e que o padrão de expressão voltava ao normal tão logo era cessada a aplicação das forças 
ortodônticas [138]. Achados como esses talvez nos ajudem a explicar o porquê de uma maior expressão de VEGF no tecido pulpar, na região de corno pulpar e, principalmente nos dentes implantados nas tíbias. Coincidentemente, essas áreas, frequentemente, apresentam-se edemaciadas e com um aspecto degenerativo.

Outro importante fator estudado por nós nas células endoteliais foi a expressão de CD105. Sobre esta proteína, nota-se que, apesar de muitos estudos a seu respeito, pouco se sabe de fato sabre a sua função [139].

A CD105 (também conhecida como endoglin) tem sido descrita como um componente auxiliar do receptor TGF- $\beta[140,141]$ mas o fato de apenas $1 \%$ das moléculas de endoglin serem capazes de se ligar ao sistema TGF- $\beta$ [140] sugeriu o seu envolvimento em outras funções não relacionadas a tal [139]. Neste sentido, estudos recentes comprovaram a relação da CD105 com proteínas não relacionadas ao TGF- $\beta$ [139]. Desde então, a expressão de CD105 foi também associada com a reorganização do citoesqueleto celular, marcando fortemente as fibras de actina intra-celulares. Isso corrobora com o fato da CD105 ser fortemente expressa de nas células endoteliais [142] visto que os filamentos de actina desempenharem um importante papel na formação de novos vasos (angiogênese) [139].

Complementariamente ao supra-exposto, estudos ainda mais recentes investigaram outras possíveis funções da CD105 e comprovaram que ela também participa do controle de algumas BMPs (BMP 2 e 7) sugerindo, o seu envolvimento na diferenciação dos osteoblastos e na produção de tecido mineralizado por estas células $[143,144]$. Outros locais de expressão de CD105 incluem as populações de pré-eritroblastos, células leucêmicas da linhagem linfóide ou mielóide e fibroblastos do estroma da medula óssea $[145,146]$.

Em nosso trabalho, a expressão de CD105 foi muito semelhante a do VEGF, tanto no grupo controle quanto nos experimentais. Dessa forma, o que pode ser visto é que, até o quinto dia vida pós-natal, os primeiros molares superiores de ratos Wistar expressam CD105 apenas nas células endoteliais dos vasos sanguíneos dentais e peridentais. A medida que o dente prossegue o seu desenvolvimento (animais D9, D13 e D17) a expressão de CD105 se dá de maneira cada vez mais intensa e uniforme, ao longo da polpa dental e do ligamento periodontal. 
Baseado no supra descrito e com base na literatura, provavelmente tal padrão de expressão de CD105 e VEGF nos dentes do grupo controle denote não somente um importante papel dessas proteínas na angiogênese do tecido pulpar e do ligamento periodontal, mas também, no caso do CD105, uma reorganização do citoesqueleto das células ao longo do desenvolvimento dental, com maior expressão de CD105 pelas fibras de actina.

Igualmente ao VEGF, o CD105 foi expresso nos dentes implantados na tíbia com um padrão similar ao encontrado no grupo controle. Nesses dentes, quanto maior o período de proservação, mais forte é a expressão de CD105, assim como, quanto mais desenvolvido é o germe dental transplantado, mais forte e mais rapidamente pode-se evidenciar a expressão de CD105. Essa mesma correlação não pode ser feita nos dentes transplantados para os rins, uma vez que os tecidos pulpares e peridentais apresentam uma expressão de CD105 fraca e focal, restrita, na maioria dos casos, ao endotélio de alguns vasos.

Com isso, se levarmos em consideração o fato de que, primeiro, a CD105 é usualmente expressa em vasos sanguíneos em desenvolvimento durante a angiogênese [66-69]; e que a CD105 raramente é encontrada nos vasos sanguíneos dos dentes transplantados para os rins, concluímos que a vascularização visualizada nestes espécimes é, predominantemente, remanescente do momento em que o dente foi transplantado e, portanto, não resultante de neoformação vascular. Ademais, podemos observar que o potencial para a formação de novos vasos nos tecidos dos dentes transplantados para os rins, que já é reduzido, decresce proporcionalmente ao tempo de permanência do germe dental no sítio receptor e aumenta proporcionalmente ao estágio de desenvolvimento do germe transplantado. Sobre esta última constatação, não acreditamos de fato que a polpa dos germes dentais de animais com 6 dias de vida possuam maior capacidade de produção de fatores angiogênicos após ser transplantado para os rins, comparativamente aos germes de animais D2, mas sim que a expressão de CD105 seja mais acentuada nos espécimes transplantados com 6 dias apenas por trazerem consigo maior concentração de fatores angiogênicos desenvolvidos in loco, previamente ao transplante, conforme pode ser observado no grupo controle. 
Seguindo o mesmo raciocínio empregado para avaliação da expressão das proteínas endoteliais VEGF e CD105, analisou-se se o desenvolvimento das células murais, ou seja, as células perivasculares e os pericitos.

Nos dentes do grupo controle, o anticorpo anti-AML deixou evidente não só as células de musculatura lisa que envolvem vasos sanguíneos, mas também as células mioepiteliais que circundam os germes dentais, estejam elas localizadas no folículo dental, no tecido conjuntivo do plexo periapical ou no ligamento periodontal. Vale ressaltar ainda que as células perivasculares e os pericitos foram mais frequentemente encontradas no grupo controle abluminalmente aos pequenos vasos sanguíneos da polpa dental e não nos mais calibrosos. Segundo a literatura, as células perivasculares dão suporte estrutural aos vasos sanguíneos de uma maneira geral e, especificamente para as arteríolas, são importantes para o controle do fluxo sanguíneo em decorrência da sua capacidade de contração [76].

Nos dentes implantados nos rins, a actina de músculo liso pode ser evidenciada em padrão muito similar ao grupo controle, os seja, nas células perivasculares dos vasos sanguíneos (mas, principalmente nos de pequeno calibre) e nos miofibroblastos localizados no tecido circunjacente ao germe dental.

Nos dentes implantados na tíbia, pode-se observar que as células perivasculares, além de circundarem os pequenos vasos, circundavam, com frequência, os vasos sanguíneos de maior calibre. Em muitos casos, diferentemente do observado nos grupos anteriores, a marcação positiva para a AML também pode ser evidenciada de maneira generalizada por fibroblastos da polpa dental. Apesar dessa última situação ter sido evidenciada em vários casos, não foi possível estabelecer uma correlação direta com o tempo de proservação pós-transplante ou com o estágio de desenvolvimento do germe transplantado.

A isoforma alfa da proteína AML usada neste estudo é, segundo a literatura, o maior constituinte do sistema de contração das células da musculatura lisa e, portanto, é considerada um marcador fenotípico de miofibroblastos [147, 148]. Os miofribloblastos são células contrácteis e secretoras, cujos progenitores são fibroblastos, que se diferenciam, geralmente, em resposta a injuria [149]. 
Acredita-se que ao menos 3 eventos locais são necessários para que ocorra a diferenciação dos fibroblastos em miofibroblastos: (I) acúmulo de TGF- $\beta$ biologicamente ativo; (II) presença de proteínas especializadas na matriz extracelular e; (III) alto nível de estresse extracelular, causando uma alteração nas propriedades da matriz extracelular e das atividades celulares [150]. Esses são motivos plausíveis para se explicar a variação na expressão de AML pelos fibroblastos da polpa dos dentes transplantados. A maior expressão de AML na polpa dos dentes transplantados para as tíbias do que os transplantados para os rins talvez seja, portanto, mais um indicativo de que o tecido pulpar se depare com um meio mais adverso ao seu desenvolvimento na tíbia do que sob a cápsula renal.

Ao se estudar o desenvolvimento dos pericitos nos germes dentais transplantados, alçamos mão do uso do anticorpo anti-PDGFR- $\beta$; reconhecido marcador das células de nosso interesse $[55,151]$. Nesse contexto, nos dentes do grupo controle, em fases mais iniciais de desenvolvimento (animais D5), o PDGFR- $\beta$ esteve nitidamente expresso nos pericitos e no tecido conjuntivo periapical e do folículo dental. Assim como o evidenciado com o VEGF e com a CD105, no decorrer do desenvolvimento dental, inesperadamente, o PDGFR- $\beta$ passou a ser expresso em todo o tecido pulpar, e ainda mais fortemente, na camada subodontoblástica.

Os dentes desenvolvidos nas tíbias tiveram um padrão de expressão imunoistoquímica de PDGFR- $\beta$ semelhante ao grupo controle, com marcação evidente dos pericitos e, adicionalmente, dos fibroblastos do tecido pulpar. Nestas células, a expressão de PDGFR- $\beta$, também é mais evidente com o passar do tempo e maior nos germes transplantados em estágio mais avançado de desenvolvimento.

Para os dentes implantados nos rins, a imunomarcação anti-PDGFR- $\beta$ é mais restrita aos pericitos e aos fibroblastos do folículo dental, valendo ressaltar ainda que raramente são evidenciados pericitos nos vasos sanguíneos da polpa dental (os pericitos estão presentes com muito mais freqüência abluminalmente aos vasos sanguíneos no folículo dental e no tecido conjuntivo periapical).

Outro imunomarcador usado com objetivo principal de identificação de pericitos foi o NG2. Esse proteoglicano é considerado um dos melhores marcadores para estudo do desenvolvimento de pericitos, especialmente em microvasculaturas, e um importante suplemento a lista dos imunomarcadores conhecidos para células 
da musculatura lisa em macrovasculaturas. Ademais, vale dizer que geralmente está super-expresso em neovasos e hipoexpresso em vasculaturas quiescentes. [83].

O NG2 foi fiel a identificação de pericitos em todos os grupos experimentais, corroborando com os achados na literatura e coincidindo com o padrão de expressão do PDGFR- $\beta$ para essas células. A interpretação desses dados nos leva a identificar, portanto, uma menor presença de pericitos nos germes transplantados, seja no rim ou na tíbia, quando comparados com o grupo controle. Além disso, nota-se que a quantidade de pericitos decresce quanto maior for 0 tempo que o dente permanecer transplantado no sítio ectópico.

Além da evidente marcação dos pericitos adjacentes aos vasos sanguíneos da polpa dental nos germes do grupo controle, o NG2 se expressou, de maneira diversa, em outras células da polpa dental ao longo do desenvolvimento dental: nos germes dentais dos primeiros molares superiores dos animais D5, o NG2 esteve fortemente presente nos odontoblastos localizados nas regiões de cúspide (região esta que, neste momento, está começando a apresentar uma deposição de dentina) e no tecido conjuntivo do plexo periapical. Nos germes dos animais D9, a expressão de NG2 começa ser evidenciada, fraca e difusamente, nos fibroblastos da polpa dental e passa a não mais ser expressa pelos odontoblastos da região de ponta de cúspide; fica mais restrita os odontoblastos com aparente atividade secretora, localizados apicalmente àqueles. Ainda nos animais D9, pode-se evidenciar a expressão de NG2 no folículo dental e, mais fortemente, no tecido conjuntivo periapical. Ao décimo terceiro dia de vida pós-natal (animais D13), a expressão de NG2 pode ser evidenciada de maneira muito forte e homogênea por quase todo o tecido pulpar e peridental. Além disso, não está expressa nos odontoblastos da coroa dental, estando restrita aos odontoblastos do terço apical da raiz. Estas últimas características são ainda mais evidentes nos germes dentais dos animais D17, corroborando a impressão de que, além de pericitos, o NG2 é um eficiente marcador de odontoblastos ativos em fase inicial de secreção.

Quando comparados os achados da expressão de NG2 no grupo controle e nos grupos experimentais, reforça-se a sensação dele ser um marcador de odontoblastos ativos por estar presente nas áreas com aparente aposição de tecido 
mineralizado (geralmente próximos a bainha radicular de Hertwig e nas regiões de dentina terciária reparativa).

Um fato muito interessante, e que vale ser ressaltado neste momento, é que praticamente só foram encontrados odontoblastos NG2 positivos nos dentes implantados nos rins e que 0 número de células positivas decrescia proporcionalmente ao tempo de desenvolvimento do dente no local e ao estágio de desenvolvimento do germe transplantado, assim, dentes de animais D6 continham uma quantidade menor de odontoblastos NG2 positivos que os de animas D2 assim como os dentes transplantados por apenas 3 dias em relação aos com 7 ou 11 dias. Intrigantemente, quando implantado nos rins, as demais células da polpa dental mostraram-se sempre negativas, não seguindo o padrão de expressão difuso e homogêneo ao longo do tecido pulpar tal qual observado nos dente do grupo controle. Paradoxalmente, a polpa dos dentes implantados na tíbia exibe um padrão de expressão de NG2 ao longo do desenvolvimento dental muito semelhante ao que ocorre no grupo controle, mas não exibe positividade em praticamente nenhum odontoblasto uma vez que essas células são raramente encontradas.

Esses dados nos sugerem que a produção de fatores angiogênicos, sejam eles relacionados às células endoteliais ou aos pericitos, é menos afetada quando o dente é transplantado para a tíbia, mas, a produção de tecidos mineralizados pelos odontoblastos é menos afetada quando os dentes são transplantados para os rins.

Sabendo-se que a proteína nestin é um marcador de tecido nervoso em fases iniciais de desenvolvimento e útil na identificação de odontoblastos [32] podemos dar seguimento ao raciocínio investigativo a respeito da formação desses tecidos.

Neste sentido, a nestin mostrou-se presente nos odontoblastos da polpa dental durante todo o período de desenvolvimento dental analisado no grupo controle (D5 a D17). É digno de nota que tal proteína também foi expressa pelos feixes nervosos, vistos lateralmente ao periápice dental, e pelo tecido conjuntivo periapical e peridental. Nos estágios mais avançados de desenvolvimento dental, a nestin foi observada de maneira difusa e fraca, na polpa dental (principalmente na camada subodontoblástica). Esse padrão de expressão de nestin é totalmente condizente com aos relatos da literatura $[32,152]$. 
Ainda dentro do contexto de análise de expressão da proteína nestin, observou-se que a mesma esteve presente praticamente apenas nos odontoblastos da polpa dos dentes transplantados para os rins, apresentado uma distribuição uniforme ao longo de toda a periferia do tecido pulpar nos mesmos. Igualmente ao grupo controle, a nestin não foi expressa na bainha radicular de Hertwig (quando esta está bem formada).

Comparativamente, quanto aos dentes eram transplantados nas tíbias, raros foram os casos onde pode ser identificado odontoblastos nestin positivos e, quando presentes, restringiam-se a regiões focais. Além disso, diferentemente dos germes implantados nos rins, a maioria dos germes implantados nas tíbias (principalmente os com maior tempo de proservação) tiveram nestin expresso em fibroblastos da polpa dental. Por fim, esta expressão variou de forte e homogênea (por todo o tecido pulpar) a fraca e focal. Talvez, esse fenótipo possa indicar um possível potencial de formação de tecido nervoso por essas células.

Em estudos realizados com dentes humanos, a nestin foi observada em diversas circunstâncias, sendo a primeira delas nos odontoblastos e nos fibroblastos da região de cúspide, em dentes na fase de campânula. Em dentes permanentes (terceiros molares hígidos de pacientes com 17 anos de idade), a expressão de nestin foi notada nos odontoblastos e em alguns fibroblastos próximos a vasos sanguíneos da polpa dental. Em dentes hígidos, provenientes de pacientes com 40 anos de idade, não foi observada expressão de nestin no tecido pulpar. Em um outro grupo de pacientes, com a mesma faixa etária do grupo anterior mas com presença de cárie ativa nos dentes, pode-se evidenciar a nestin em odontoblastos próximos a lesão cariosa. Por fim, dentes de indivíduos adultos revelaram presença de nestin na camada de odontoblastos próxima a preparo cavitário após 9 semanas da realização destes [152]. Achados como esses corroboram com outros estudos que indicam que essa proteína é, entre outras coisas, um marcador de odontoblastos [32].

Além da nestin, a proteína S100 também foi utilizada como método auxiliar no estudo do desenvolvimento do sistema nervoso nos dentes estudados nesta pesquisa. Embora o mecanismo exato do desenvolvimento de tal sistema nos dentes ainda permaneça obscuro, sabe-se que os odontoblastos possuem um papel 
chave na sensibilidade dos dentes. Não se sabe se isso pode se dar tanto pelo fato de se acreditar que os odontoblastos dão estabilidade a um compartimento dentinário/pré-dentinário no qual o fluido dentinário está confinado ou ainda por possuirem capacidade de conduzir os impulsos nervosos diretamente as vias de sinalização nervosas [116].

A literatura relata o início do desenvolvimento nervoso na polpa dental nos primeiros molares de ratos a partir do quinto dia de vida pós-natal [153]. Em nosso caso, em animais D5, foi possível visualizar células S100 positivas apenas no periápice dental e no feixe nervoso localizado lateralmente a este, mas, nos dentes de animais D9, já foi possível visualizar, embora de forma discreta, fibras nervosas perivasculares e na camada odontoblástica e subodontoblástica. Nos dentes de animais D13 e D17, a marcação para a proteína S100 já pode ser evidenciada ao longo de todo o tecido da polpa dental e, de maneira ainda mais evidente, nos tecido conjuntivo periapical e no ligamento periodontal, denotando, portanto a rica inervação destas regiões.

Em contrapartida, em nenhum dos germes transplantados para os rins, independentemente do tempo de proservação ou do estágio de desenvolvimento do germe dental no momento do transplante, foi possível evidenciar células S100 positivas na polpa dental. Nos casos dos dentes transplantados para as tíbias, alguns raros casos apresentaram fraca marcação para o S100, de maneira difusa, em células da polpa dental, não permitindo que concluíssemos se tratava-se de fato de uma macacão positiva ou se era apenas um artefato de técnica. 
Conclusões 


\section{CONCLUSÕES}

\subsection{Quanto ao estágio de desenvolvimento dental:}

A) A polpa dental possui um aporte sanguíneo satisfatório independentemente do estágio de desenvolvimento do germe transplantado, mas este diminui quanto maior o tempo de permanência no sitio ectópico;

B) O padrão de expressão dos marcadores vasculares e perivasculares sofre alteração de acordo com o período que o germe permanece no leito receptor;

C) A presença de pericitos é menor nos dentes transplantados em fases mais avançadas de desenvolvimento e decresce proporcionalmente ao período de tempo de proservação;

D) O padrão de expressão de marcadores de tecido nervoso independe do estágio de desenvolvimento do germe transplantado;

E) Independentemente do sítio de transplante, a produção de tecidos mineralizados pelos odontoblastos e ameloblastos é muito menor nos germes transplantados em fases mais tardias de desenvolvimento e aumenta de acordo com o tempo de permanência do germe dental no leito receptor.

\subsection{Quanto à presença de tecido ósseo no sítio ectópico de transplante:}

A) Morfologicamente, o dente apresenta-se mais comprometido quando transplantado para a tíbia (sitio onde o tecido ósseo esta presente);

B) A presença do tecido ósseo não afetou o processo de neovascularização após o transplante e a expressão dos das proteínas CD105, VEGF, AML, 
PDGFR- $\beta$ e NG2 no grupo de dentes transplantados na tíbia é mais semelhante ao padrão encontrado no grupo controle;

C) A expressão de marcadores de tecido nervoso raramente é evidenciada após o transplante nas tíbias e ausente nos germes transplantados para os rins;

D) A presença de tecido ósseo suscita a reabsorção do germe dental por células clásticas, fato este não observado nos germes implantados nos rins;

E) Há maior presença de infiltrado inflamatório na polpa dos germes implantados nas tíbias, em especial nos dias iniciais da recuperação;

F) Os odontoblastos permanecem viáveis em menor número quando os dentes são transplantados para as tíbias e nesses casos a produção de osteodentina é rara e restrita a região da bainha epitelial de Hertwig.

\subsection{Quanto à posição de implantação:}

A) A posição de implantação do germe dental na tíbia não afeta o desenvolvimento nervoso e vascular, mas, morfologicamente, os dentes se desenvolvem melhor quando implantados com a polpa voltada para o espaço medular. 


\section{REFERÊNCIAS ${ }^{*}$}

1. Baratieri LN. Odontologia restauradora: fundamentos e possibilidades. São Paulo: Quintessence; 2002.

2. Young CS, et al. Tissue engineering of complex tooth structures on biodegradable polymer scaffolds. J Dent Res. 2002;81:695-700.

3. Ohazama A, et al., Stem-cellbased tissue engineering of murine teeth. J Dent Res. 2004;83:518-22.

4. Kollar EJ, Baird GR. Tissue interactions in embryonic mouse tooth germs. The inductive role of the dental papilla. J Embryol Exp Morphol. 1970;24:173-86.

5. Katchburian E, Arana V. Histologia e Embriologia Oral. 1 ed. São Paulo: Editora Médica Panamericana; 1999.

6. Dassule HR, McMahon AP. Analysis of Epithelial-Mesenchymal Interactions in the Initial Morphogenesis of the Mammalian Tooth. Develop Biol 1998;202:215-27.

7. Biz, M.T., Distribuição, expressão e papel das GTPases RhoA e Rac1 nas fases iniciais de desenvolvimento do germe dentário e desenvolvimento de ameloblastos e odontoblastos [tese]. São Paulo: Universidade de São Paulo, Centro de Ciências Biomédicas; 2007.

8. Fried K, et al. Molecular Signing and Pulpal Nerve Devepment. Crit Rev Oral Biol Med. 2000;11(3):318-32.

9. Lumsden AGS. The developing innervation of the lower jaw and its relation to the formation of tooth germs in mouse embryos. In: Teeth: form, function and evolution. New York: Columbia University Press; 1982.

*De acordo com Estilo Vancouver 
10. Lumsden AGS. The neural crest contribution to tooth development in the mammalian embryo. In: Developmental and evolutionary aspects of the neural crest. New York: Wiley; 1987.

11 Lumsden AGS. Spatial organization of the epithelium and the role of neural crest cells in the initiation of the mammalian tooth germ. Development 1988; 103:155-69.

12. Mina M, Kollar EJ. The induction of odontogenesis in non-dental mesenchyme combined with early murine mandibular arch epithelium Arch Oral Biol. 1987;32:123-27.

13. Luukko K, et al. Neurotrophin mRNA expression in the developing tooth suggests multiple roles in innervation and organogenesis. Dev Dyn. 1997; 210:117-129.

14. Mohamed SS, Atkinson ME. A histological study of the innervation of developing mouse teeth. J Anat 1983;136(4):735-49.

15. Sharpe P. Homeobox genes and orofacial development. Connect Tissue Res. 1995;32:17-25.

16. Thesleff I, Nieminen P. Tooth morphogenesis and cell differentiation. Curr Opin Cell Biol. 1996;8:844-50.

17. Luukko K. Immunohistochemical localization of nerve fibres during development of embryonic rat molar usin peripherin and potein en product 9.5 antibodies. Archs Oral Biol. 1997;42(3):189-95.

18. Hildebrand $\mathrm{C}$, et al. Teeth and tooth nerves. Progr Neurobiol. 1995;45:165-222.

19. Fried $\mathrm{K}$, Hildebrand C. Pulpal axons in developing, mature, and aging feline permanent incisors. A study by electron microscopy. J Comp Neurol. 1981;203:23-36. 
20. Heizmann C. The multifunctional S100 protein family. Methods Mol Biol. 2002;172:69-80.

21. Zimmer DB, Chessher JC e Song W, Nucleotide homologies in genes encoding members of the S100 protein family Biochem Biophys Acta 1996;1313:229-38.

22. Moore BM. A soluble protein characteristic of the nervous system. Biochem Biophys Res Commun 1965;19:739-44.

23. Cocchia $D$, Michetti $F$ e Donato R. S100 antigen in normal human skin. Nature 1981;294:85-7.

24. Donato R. S100 proteins. Cell Calcium 1986;123-45.

25. Barrett AW e Scully C. S100 protein in oral biology and pathology. J Oral Pathol Med 1994;23(10):433-40.

26. Donato R. Perspectives in S-100 protein biology. Cell Calcium 1991;12:713-26.

27. Marenholz I, Heizmann CW, Fritz G. S100 proteins in mouse and man: from evolution to function and pathology (including an update of the nomenclature. Biochem Biophys Res Commun. 2004;322(4):1111-22.

28. Schäfer BW, et al. Isolation of a YAC clone covering a cluster of nine S100 genes on human chromosome 1q21: rationale for a new nomenclature of the S100 calcium-binding protein family. Genomics $1995 ; 25: 638-43$.

29. Schäfer BW, HeizmannCW. The S100 family of EFhand calcium-binding proteins: functions and pathology. Trends Biochem Sci 1996;21:134-40.

30. Heizmann C. The multifunctional S100 protein family. Methods Mol Biol 2002;172:69-80. 
31. Heizmann CW, Cox JA. New perspectives on S100 proteins: a multifunctional $\mathrm{Ca}, \mathrm{Zn}$ and $\mathrm{Cu}$-binding protein family Bio-Metals 1998;11:383-97.

32. Terling $\mathrm{C}$, et al. Expression of the intermediate filament nestin during rodent tooth development. Int J Dn Biol. 1995;39:947-56.

33. Wiese $\mathrm{C}$, et al. Nestin expression--a property of multi-lineage progenitor cells? Cell Mol Life Sci. 2004;61:2510-22.

34. Sejersen $\mathrm{T}$, Iendahal $\mathrm{U}$. Transient expression of the intermediate filament nestin during skeletal muscle development. J Cell Sci 1993;106:1291-300.

35. Lendahl U, Zimmerman LB, McKAY RDG. CNS stem cells express a new class 01 Intermediate filament protein. Cell 1990;60:585-95.

36. Dahlstrand J, et al. Characterization of the human nestin gene reveals a close evolutionary relationship to neurofllaments. J Cell Sci 1992;103:589-97.

37. Frederiksen K, McKay RDG. Proliferation and differentiation 01 rat neuroepithelial precursor cells in vivo. J Neurosci 1986;8:1144-51.

38. Messam CA, Hou J, Major EO. Coexpression of nestin in neural and glial cells in the developing human CNS defined by a human-specific antinestin antibody. Exp Neurol 2000.161(2):585-96.

39. Reyes $\mathrm{M}$, et al. Origin of endothelial progenitors in human postnatalbone marrow J Clin Invest. 2002;3:337-46.

40. Schmeisser A, Strasser RH. Phenotypic overlap between hematopoietic cells with suggested angioblastic potential and vascular endothelial cells. J Hematother Stem Cell Res 2002;11: 69-79.

41. Moore MAS. Putting the neo into neoangiogenesis. J Clin Invest 2002;109:313-15. 
42. Carmeliet P. Mechanisms of angiogenesis and arteriogenesis. Nature Med 2000;6:389-95.

43. Carmeliet P. One cell, two fates. Nature 2000;408(2):43-4.

44. Yamaguchi TP, et al. Flk1, a flt-related receptor tyrosine kinase is an early marker for endothelial precursors. Development 1993;118:489-98.

45. Topouzis S, Majesky MW. Smooth muscle lineage diversity in the chick embryo - Two types of aortic smooth muscle cell differ in growth and receptor-mediated transcriptional responses to transforming growth factor-b. Dev Biol 1996;178:430-45.

46. Jiang $X$, et al. Fate of the mammalian cardiac neural crest Development 2000;127:1607-16.

47. Mikawa T, Gourdie RG. Pericardial mesoderm generates a population of coronary smooth muscle cells migrating into the heart along with in growth of the epicardial organ. Dev Biol 1996;174:221-32.

48. Groot ACG, et al. Smooth muscle cell origin and its relation to heterogeneity in development and disease. Arterioscler Thromb Vasc Biol 1999:1589-94.

49. Folkman J, D'Amore PA. Blood vessel formation:What is its molecular basis? Cell 1996;87:1153-55.

50. Canfield $A E$, et al. Association of thrombospondin-1 with osteogenic differentiation of retinal pericytes in vitro. J Cell Sci. 1996;109(2):343.

51. Schor AM, et al. Pericyte differentiation. Clin Orthop Relat Res. 1995;81.

52. Allt G, Lawrenson JG. Pericytes: Cell biology and pathology. Cells Tissues Organs 2001;169(1):1-11. 
53. Sims DE, Westfall JA. Analysis of relationships between pericytes and gas exchange capillaries in neonatal and mature bovine lungs. Microvasc Res. 1983;25:333.

54. Sims DE, et al. Ultrastructure of pericytes in early stages of histamineinduced inflammation. J Morphol. 1990;206:333.

55. Sims DE. Diversity within pericytes. Clin Exp Pharmacol Physiol 2000;27:842.

56. Shepro D, Morel NM. Pericyte physiology. FASEB J 1993;7:1031.

57. Bergers $\mathrm{G}$, $\mathrm{S}$ Song. The role of pericytes in blood-vessel formation and maintenance. Neuro-Oncol 2005;7:452-64.

58. Ferrara N, Gerber HP. The role of vascular endothelial growth factor in angiogenesis. Acta Haematol 2002.106(4):148-56.

59. Ladoux A, Frelin C. Expression of vascular endothelial growth factor by cultured endothelial cells from brain microvessels. Biochem Biophys Res Commun 1993;194(2):799-803.

60. Ferrara N, Winer J, Burton T. Aortic smooth muscle cells express and secrete vascular endothelial growth factor. Growth Factors $1991 ; 5(2): 141-8$.

61. Nomura M, et al. Possible Participation of Autocrine and Paracrine Vascular Endothelial Growth Factors in Hypoxia-induced Proliferation of Endothelial Cells and Pericytes. J Biol Chemi 1995;270(47):28316-24.

62. Rafii SJ. Circulating endothelial precursors: mystery, reality, and promise. Clin Invest. 2000;105:17-9.

63. Artese $L$, et al. Vascular endothelial growth factor (VEGF) expression in healthy and inflamed human dental pulps. J Endod. 2002;28:20-3. 
64. Roberts-Clark DJ, Smith AJ. Angiogenic growth factors in human dentine matrix. Arch Oral Biol. 2000;45:1013-6.

65. Hasan J, Byers R, Jayson GC. Intra-tumoural microvessel density in human solid tumours. Rev Br J Cancer 2002;86:1566-77.

66. Saad RS, et al. Endoglin (CD105) and vascular endothelial growth factor as prognostic markers in colorectal cancer Modern Pathol. 2004;17:197203.

67. Kumar P, Wang JM, Bernabeu C. CD 105 and angiogenesis. J Pathol 1996;178:363-6.

68. Seon BK, et al. Longlasting complete inhibition of human solid tumors in SCID mice by targeting endothelial cells of tumor vasculature with antihuman endoglin immunotoxin. Clin Cancer Res. 1997;3:1031-44.

69. Wang JM, et al. A monoclonal antibody detects heterogeneity in vascular endothelium of tumours and normal tissues. Int J Cancer 1993;54:36370.

70. Brewer CA, et al. Endoglin expression as a measure of microvessels density in cervical cancer. Obstet Gynecol 2000;96:224-28.

71. Saad RS, Jasnosz KM, Silverman JF. Endoglin (CD105) expression in endometrial carcinoma. Int J Gynecol Pathol 2003;22:248-53.

72. Bodey B, et al. Over-expression of endoglin (CD 105): a marker of breast carcinomainduced neovascularization. Anticancer Res 1998.18:3621-628.

73. Martonea T, et al. Prognostic relevance of CD105+ microvessel density in HNSCC patient outcome. Oral Oncol 2005;41:147-55.

74. Hellstrom M, et al. Role of PDGF-B and PDGFR-beta in recruitment of vascular smooth muscle cells and pericytes during embryonic blood vessel formation in the mouse. Development. 1999;126:3047-55. 
75. Hughes S, Chan-Ling T. Characterization of smooth muscle cells and pericyte differentiation in the rat retina in vivo. Invest Ophthalmol Vis Sci 2004;45:2795-806.

76. Gerhardt $\mathrm{H}$, Betsholtz $\mathrm{C}$. Endothelial-pericyte interactions in angiogenesis Cell Tissue Res 2003;22:15-23.

77. Tilton RG, Kilo C, Williamson JR. Pericyte-endothelial relationships in cardiac and skeletal muscle capillaries. Microvasc Res 1979;18:325-35.

78. Grako KA e Stallcup WB. Participation of the NG2 proteoglycan in rat aortic smooth muscle cell responses to platelet-derived growth factor. Exp Cell Res. 1995;221:231-40.

79. Miller B, et al. Chondroitin sulfate proteoglycans in the developing cerebral cortex: the distribution of neurocan distinguishes forming afferent and efferent axonal pathways. J Comp Neurol. 1995;55:615-28.

80. Nishiyama A, et al. Co-localization of NG2 proteoglycan and PDGF alphareceptor on O2A progenitor cells in the developing rat brain. J Neurosci Res 1996;43:299-314.

81. Schlingemann RO, et al. Expression of the high molecular weight melanoma-associated antigen by pericytes during angiogenesis in tumors and in healing wounds. Am J Pathol 1990;136:1393-405.

82. Burg MA, et al. NG2 proteoglycan-binding peptides target tumor neovasculature. Cancer Res 1999;59:2869-74.

83. Ozerdem $\mathrm{U}$, et al. The NG2 proteoglycan is expressed exclusively by mural cells during vascular morphogenesis. Dev Dyn, 2001;222:218-27.

84. GeneBanck, http://www.ncbi.nlm.nih.gov/sites/entrez?Db=gene\&Cmd=ShowDetailVi ew\&TermToSearch=5159. Acessado em 16 de março de 2010.

85. Lindahl $\mathrm{P}$, et al. Pericyte loss and microaneurysm formation in PDGF-Bdeficient mice. Science 1997;277:242-45. 
86. Soriano P. Abnormal kidney development and hematological disorders in PDGF beta-receptor mutant mice. Genes Dev. 1994;8:1888-96.

87. Crosby JR, et al. Chimaeric analysis reveals role of Pdgf receptors in all muscle lineages. Nat Genet 1998;18:385-88.

88. Langer R, Vacanti JP. Tissue engineering. Science 1993;260:920-26.

89. Modino ACS, Sharpe PT. Tissue engineering of teeth using adult stem cells. Archi of Oral Biol, 2005;50:255-58.

90. El-Backly RM, et al. Regeneration of dentine/pulp-like tissue using a dental pulp stem cell/poly(lactic-co-glycolic) acid scaffold construct in New Zealand white rabbits. Aust Endod J. 2008;34:52-67.

91. Handa K, et al. Cementum Matrix Formation In Vivo by Cultured Dental Follicle Cells. Bone 2002;31(5):606-11.

92. Huang GT-J, et al. The Hidden Treasure in Apical Papilla: The Potential Role in Pulp/Dentin Regeneration and BioRoot Engineering. J Endod. 2008;34(6):645-51.

93. Iohara K, et al. Side Population Cells Isolated from Porcine Dental Pulp Tissue with Self-Renewal and Multipotency for Dentinogenesis, Chondrogenesis, Adipogenesis, and Neurogenesis. Stem Cells 2006;24:2493-503.

94. Li Y, et al. Cementum and Periodontal Ligament-like Tissue Formation Induced Using Bioengineered Dentin. Tissue Engin 2008;14(10):1731-42.

95. Fang $D$, et al. Transplantation of Mesenchymal Stem Cells Is an Optimal Approach for Plastic Surgery. Stem Cells 2007;25:1021-28.

96. Costa ADM, et al. Reconstruction of Large Cranial Defects in Nonimmunosuppressed Experimental Design With Human Dental Pulp Stem Cells. J Craniofac Surg. 2008;19(1):204-10. 
97. Kerkis I, et al. Early transplantation of human immature dental pulp stem cells from baby teeth to golden retriever muscular dystrophy (GRMD) dogs: Local or systemic? J Trans Med. 2008;6(35):1-13.

98. About I, et al. Human dentin production in vitro. Exp Cell Res. $2000 ; 258: 33-41$.

99. Batouli S, et al. Comparison of stem-cell-mediated osteogenesis and dentinogenesis. J Dent Res. 2003;82:976-81.

100. Gronthos S, et al. Postnatal human dental pulp stem cells (DPSCs) in vitro and in vivo. Proc Natl Acad Sci USA 2000;97:13625-630.

101. Gronthos S, et al. Stem cell properties of human dental pulp stem cells. J Dent Res. 2002;81:531-35.

102. Miura M, et al. SHED: stem cells from human exfoliated deciduous teeth. Proc Natl Acad Sci USA 2003;100:5807-12.

103. Duailibi MT, et al. Bioengineered Teeth from cultured rat tooth bud cells. J Dent Res 2004;83(7):523-28.

104. Duailibi SE, et al. Bioengineered dental tissues grown in the rat jaw. J Dent Res. 2008;87(8):745-50.

105. Zhang W, et al. Tissue engineered hybrid tooth-bone constructs. Methods 2009;47:122-28.

106. Ohazama $A$, et al. Stem-cellbased tissue engineering of murine teeth. J Dent Res. 2004;83:518-22.

107. Thesleffa I, Sharpe PT. Signalling networks regulating dental development. Mech Develop 1997;67:111-23. 
108. Hu B, et al. Dental epithelial histo-morphogenesis in the mouse: positional information versus cell history. Arch Oral Biol. 2005;50:13136.

109. Hu B, et al. Tissue engineering of tooth crown, root, and periodontium. Tissue Eng. 2006;12:2069-75.

110. Ikeda $\mathrm{E}$, et al. Fully functional bioengineered tooth replacement as an organ replacement therapy. PNAS 2009;106(32):13475-480.

111. Honda MJ, et al. Preliminary study of tissue-engineered odontogenesis in the canine jaw. J Oral Maxillofac Surg. 2006;64:283-89.

112. Yen AH-H e Sharpe PT. Stem cells and tooth tissue engineering. Cell Tissue Res 2008;331:359-72.

113. Yoshikawa DK, Kollar EJ. Recombination experiments on the odontogenic roles of mouse dental papilla and dental sac tissues in ocular grafts. Arch Oral Biol 1981;26:303-07.

114. Slavkin HC, Bavetta LA. Odontogenesis in vivo and in xenografts on chick chorio-allantois. I. Collagen and hexosamine biosynthesis Arch Oral Biol 1968;13:145-54.

115. Goldberg M, Smith AJ. Cells and extracellular matrices of dentin and pulp: a biological basis for repais and tissue engineering. Crit Rev Oral Biol Med 2004;15(1):13-27.

116. Arana-Chavez VE e Massa LF. Odontoblasts: the cells forming and maintaining dentine. Intl J of Biochemi \& Cell Biol 2004;36:1367-73.

117. Aguiar MC, Arana-Chavez VE. Immunocytochemical detection of dentine matrix protein 1 in experimentally induced reactionary and reparative dentine in rat incisors. Archi O Biol 2010;55(3):210-14.

118. Goldberg M, Smith AJ. Cells and extracellular matrices of dentin and pulp: a biological basis for repair and tissue engineering. Crit Rev Oral Biol Med. 2004;15:13-27. 
119. Smith $\mathrm{AJ}$, et al. Odontoblast stimulation in ferrets by dentine matrix components. Arch Oral Biol 1994;39:13-22.

120. Lesot $\mathrm{H}$, et al. Experimental induction of odontoblast differentiation and stimulation during reparative processes. Cell Mater 1993;3:201-17.

121. Arana-Chavez VE, Bradaschia-Correa V. Clastic cells: Mineralized tissue resorption in health and disease. Inter J Biochemi \& Cell Biol 2009;41:446-50.

122. Lerner UH. Matrix biology, osteoclast formation and resorption. Matrix Biol. 2000;19:107-20.

123. Leung DW, et al. Vascular endothelial growth factor is a secreted angiogenic mitogen. Science 1989;246:1306-09.

124. Senger DR, et al. Tumour cells secrete a vascular permeability factor that promotes accumulation of ascites fluid. Science 1983;219:983-85.

125. Kuroki M, Voest EE, Amano S. Reactive oxygen intermediates increase vascular endothelial growth factor expression in vitro and in vivo. J Clin Invest. 1996;7:1667-75.

126. Senger DR, et al. Tumor cells secrete a vascular permeability factor that promotes accumulation of ascites fluid. Science 1983;219:983-85.

127. Barleon B, et al. Migration of human monocytes in response to vascular endothelial growth factor (VEGF) is mediated via the VEGF receptor flt-1. Blood 1996;87:3336-43.

128. Niida $S$, et al. Vascular endothelial growth factor can substitute for macrophage colony-stimulating factor in the support of osteoclastic bone resorption. J Exp Med. 1999;190:293-98. 
129. Aldridge $\mathrm{SE}$, et al. Vascular endothelial growth factor receptors in osteoclast differentiation and function. Biochem Biophys Res Commun 2005;335:793-98.

130. Mayr-Wohlfart $U$, et al. Vascular endothelial growth factor stimulates chemotactic migration of primary human osteoblasts. Bone 2002;30:47277.

131. Street J, et al. Vascular endothelial growth factor stimulates bone repair by promoting angiogenesis and bone turnover. Proc Natl Acad Sci USA 2002;99:9656-61.

132. Johnson RB, Serio FG, Dai X. Vascular endothelial growth factor and progression of periodontal diseases. J Periodontol 1999;70:848-52.

133. Goodis $H$, Saeki K. Identification of bradykinin, substance $P$, and neurokinin A in human dental pulp. J Endod. 1997;23:201-04.

134. Miyauchi $M$, et al. Immunohistochemical demonstration of prostaglandin E2, F2alpha, and 6-keto-prostaglandin F1alpha in rat dental pulp with experimentally induced inflammation. J Endod. 1996;22:600-02.

135. Stashenko P, Teles R, D'Souza R. Periapical inflammatory responses and their modulation. Crit Rev Oral Biol Med. 1998;9:498-521.

136. Li J, Parella MA, Tsai JC. Induction of vascular endothelial growth factor gene expression by interleukin-1 beta in rat aortic smooth muscle cells. J Biol Chem. 1995;270:308-12.

137. Ben-Av $P$, et al. Induction of vascular endothelial growth factor in synovial fibroblasts by prostaglandin $E$ and interleukin-1: a potential mechanism for inflammatory angiogenesis. FEBS Lett 1995;372:83-87.

138. Miyagawa $A$, et al. Compressive force induces VEGF production in periodontal tissues. J Dent Res. 2009;88(8):752-56. 
139. Sanz-Rodriguez $F$, et al. Endoglin regulates cytoskeletal organization through binding to ZRP-1, a member of the lim family of proteins. J Biol Chemi 2004;279(31):32858-68.

140. Cheifetz S, et al. Endoglin is a component of the transforming growth factor-beta receptor system in human endothelial cells. J Biol Chem 1992;267(27):19027-30.

141. Lastres $\mathrm{P}$, et al. Endoglin modulates cellular responses to TGF-beta 1. J Cell Biol. 1996;133(5):1109-21.

142. Gougos A e Letarte M. Primary structure of endoglin, an RGD-containing glycoprotein of human endothelial cells. J Biol Chem. 1990;265(15):8361-4.

143. Scherner $O$, et al. Endoglin differentially modulates antagonistic transforming growth factor-beta1 and BMP-7 signaling. J Biol Chem. 2007;282:13934-43.

144. Ishibashi O, et al. Endoglin is involved in BMP-2-induced osteogenic differentiation of periodontal ligament cells through a pathway independent of smad-1/5/8 phosphorylation. J Cell Physiol. 2010;222:465-73.

145. Buhring $\mathrm{H}-\mathrm{J}$, et al. Endoglin is expressed on a subpopulation of immature erythroid cells of normal human bone marrow. Leukemia. 1991;5(10):841-7.

146. Gougos A, Letarte M. Identification of a human endothelial cell antigen with monoclonal antibody 44G4 produced against a pre-B leukemic cell line. J Immunol 1988;141(6):1925-33.

147. Vaughan MB, Howard EW, Tomasek JJ. Transforming growth factor-beta 1 promotes the morphological and functional differentiation of the myofibroblast. Exp Cell Res 2000;25:180-9.

148. Hinz B, et al. The myofibroblast: one function, multiple origins. Am J Pathol. 2007;170:1807-16. 
149. Hinz B. Formation and function of the myofibroblast during tissue repair. J Invest Dermatol 2007;127:526-37.

150. Tomasek JJ, et al. Myofibroblasts and mechano-regulation of connective tissue remodeling. Nat Rev Mol Cell Biol 2002;3:349-63.

151. Bernstein LR, Antoniades $\mathrm{H}$, Zetter B. Migration of cultured vascular cells in response to plasma and platelet-derived factors. J Cell Sci 1982;56:7182.

152. About I, et al. Nestin expression in embryonic and adult human teeth under normal and pathological conditions. Am J Pathol. 2000;157(1):287-95.

153. Byers MR. Development of sensory innervation in dentin. J Comp Neurol 1980;191:413-27. 


\section{APÊNDICE A}

Protocolo utilizado para o processamento histológico de material biológico obtido de experimentação com o intuito de inclusão do mesmo em parafina para posterior corte e análise histológica.

Todo o material foi previamente identificado e acondicionado em recipientes individuais próprias chamados Cassetes (Biopsy Uni-Cassete, marca Tissue-Teck ${ }^{\circledR}$, \# 4086) e encaminhado para o processamento histotécnico automatizado de acordo com o protocolo abaixo:

- Álcool 70\% por 1:30h

- Álcool 80\% por 1:30h

- Álcool 90\% por 1:30h

- Álcool 95\% por 1:30h

- Álcool absoluto (I) por 1:30h

- Álcool absoluto (II) por 1:30h

- Álcool absoluto (III) por 1:30h

- Álcool/Xilol (proporção de 1:1) por 1:30h

- Xilol (I) por 1:30h

- Xilol (II) por 1:30h

- Parafina (I) por 1:30h

- Parafina (II) por 1:30h 


\section{APÊNDICE B}

Os cortes histológicos foram dispostos de maneira ordenada (ocupando as posição de 1 a 40) sob lâminas histológicas (conforme mostra figura abaixo) que continham as seguintes informações:

- Identificação do animal (Animal X, por exemplo)

- Identificação da bateria de lâminas: identificada com letras maiúsculas, em ordem alfabética, acompanha o grupo de cada 5 lâminas cortadas sequencialmente e pertencentes a um mesmo animal. A quantidade de baterias era diretamente proporcional ao montante de material cortado.

- Número de série da lâmina: identifica a ordem de montagem das lâminas de uma mesma bateria. Foi padronizado que cada bateria teria 5 lâminas e, portanto, o número de série varia de 1 a 5.

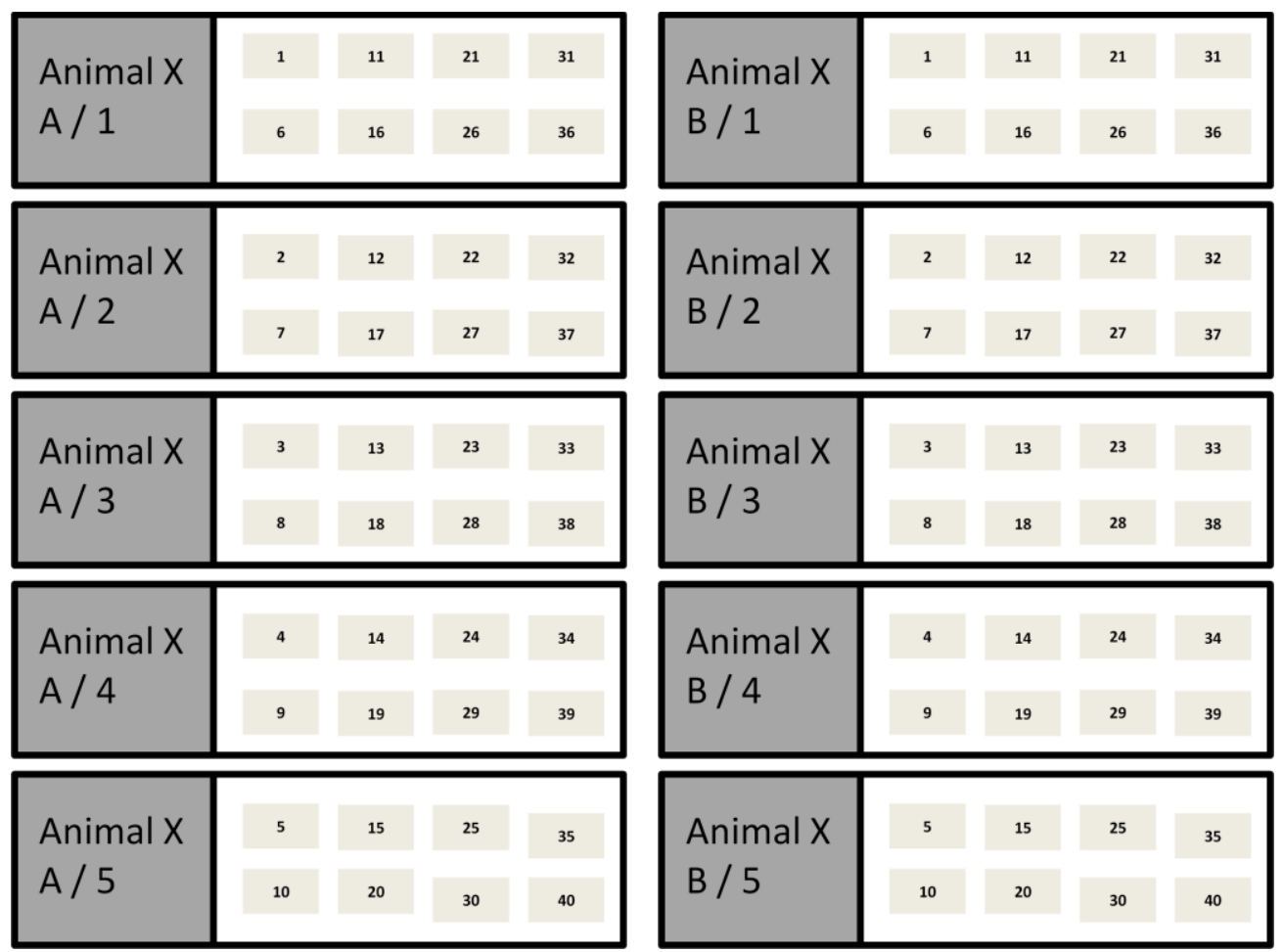

Exemplo de 2 baterias de lâminas com 5 séries cada. 


\section{APÊNDICE C}

Coloração com Hematoxilina de Harris e Eosina Alcoólica (HE) realizada de forma automatizada em aparelho Tissue-Tek DRS, marca SACURA, seguindo o protocolo:

Imersão das lâminas em:

- Xilol (I) por $5 \mathrm{~min}$

- Xilol (II) por $5 \mathrm{~min}$

- Álcool absoluto por $5 \mathrm{~min}$

- Álcool 95\% por 5 min

- Álcool $90 \%$ por $5 \mathrm{~min}$

- Álcool 80\% por 5 min

- Água destilada corrente por $5 \mathrm{~min}$

- Hematoxilina por 5 min

- Água destilada corrente por $5 \mathrm{~min}$

- Álcool 80\% por 30 segundos

- Eosina alcoólica por 2 min

- Água corrente por 30 segundos

- Álcool 80\% por 3 min

- Álcool 90\% por $3 \mathrm{~min}$

- Álcool 95\% por 3 min

- Álcool absoluto por 3 min

- Xilol (III) por 5 min

- Xilol (IV) por 5 min 


\title{
ANEXO A
}

\author{
Universidade de São Paulo \\ Faculdade de Odontologia \\ Comitê de Ética em Pesquisa
}

\section{PARECER DE APROVAÇĀO}

Protocolo 05/09

Com base em parecer de relator, o Comitê de Ética em PesquisaSubcomissão de Bioética de Animais da FOUSP, APROVOU o protocolo de pesquisa: "Transplante de germe dental: estudo da correlação entre posição do implante, presença de tecido ósseo no leito receptor e fase de desenvolvimento do germe transplantado com a formação de tecido nervoso e vascular no dente". de responsabilidade do Pesquisador: Felipe Perozzo Daltoé, sob orientaçăo da Professora Doutora Andrea Mantesso.

Cabe ao responsável enviar relatórios referentes ao andamento da pesquisa após 06 (seis) meses e 01 (um) ano desta data, bem como cópia do trabalho em "cd" ou "disquete" ao finalizá-lo, conforme legislaçāo vigente.

Săo Paulo, 16 de março de 2009.

Prof. Dr. Celso Luiz CALdeira

PRESIDENTE DA SUB-COMISSÄO dE BIOÉTICA DE ANIMAIS DA FOUSP 